Pacific Northwest

National Laboratory

Operated by fiatelle for the

US. Department of Energy

\section{RCRA Assessment Plan for Single-Shell Tank Waste Management Area T at the $\mathrm{H}$ anford Site}

\author{
F. N. Hodges \\ C. J. Chou
}

February 2001

Prepared for the U.S. D epartment of Energy under Contract DE-AC06-76RL01830 


\section{DISCLAIMER}

This report was prepared as an account of work sponsored by an agency of the United States Government. Reference herein to any specific commercial product, process, or service by trade name, trademark, manufacturer, or otherwise does not necessarily constitute or imply its endorsement, recommendation, or favoring by the United States Government or any agency thereof, or Battelle Memorial Institute.

\section{PACIFIC NORTHWEST NATIONAL LABORATORY \\ operated by \\ BATTELLE \\ for the \\ UNITED STATES DEPARTMENT OF ENERGY \\ under Contract DE-AC06-76RL01830}

Printed in the United States of America

Available to DOE and DOE contractors from the

Office of Scientific and Technical Information, P.O. Box 62, Oak Ridge, TN 37831;

prices available from $(615) 576-8401$.

Available to the public from the National Technical Information Service,

U.S. Department of Commerce, 5285 Port Royal Rd., Springfield, VA 22161

This document was printed on recycled paper. 


\title{
RCRA Assessment Plan for Single-Shell Tank Waste Management Area T at the Hanford Site
}

\author{
F. N. Hodges \\ C. J. Chou
}

February 2001

Prepared for

the U.S. Department of Energy

under Contract DE-AC06-76RL01830

Pacific Northwest National Laboratory

Richland, Washington 99352 


\section{Summary}

A groundwater quality assessment plan was prepared to investigate the rate and extent of aquifer contamination beneath Waste Management Area T at the Hanford Site. The "first determination," concluded Waste Management Area T is contributing to groundwater contamination; therefore, a continued assessment is required. The plan described here implements this RCRA requirement, 40 CFR 265.93 (d)(7). This plan is an update of a draft plan issued in January 1999, which guided work performed in fiscal year 2000. Planned activities for fiscal year 2001 and beyond include additional groundwater sampling and analysis, hydraulic testing to further define flow rate and direction, and installation of additional wells to improve the detection monitoring network and to better define the areal and vertical extent of contamination. Four new downgradient wells to enhance spatial coverage will be completed during calendar year 2000. Five new wells (subject to funding) are planned for calendar year 2001 to further define areal and vertical extent and to help distinguish tank leak sources from upgradient crib sources.

The results of this groundwater quality assessment will be provided to the RCRA Facility Investigation Corrective Measures Study (RFI/CMS) conducted by the River Protection Program to investigate the vadose zone sources of observed groundwater contamination beneath Waste Management Area T. The groundwater quality assessment and the RFI/CMS work will be conducted under separate but coordinated plans. Results from the groundwater investigation together with the RFI/CMS will provide information to support decisions on interim measures, corrective measures, waste retrieval, and eventual closure of the tank farms. 


\section{Contents}

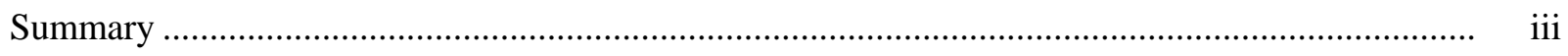

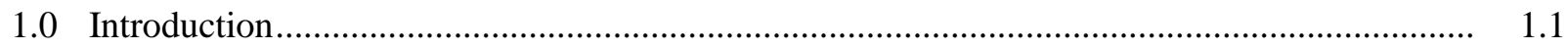

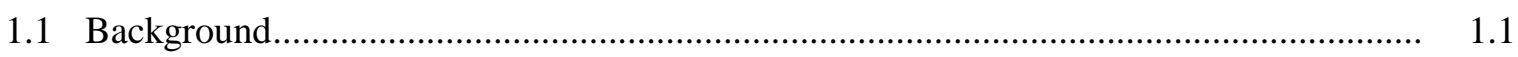

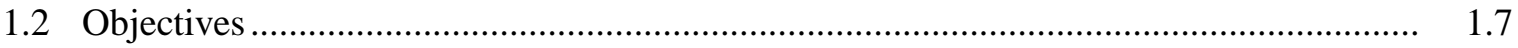

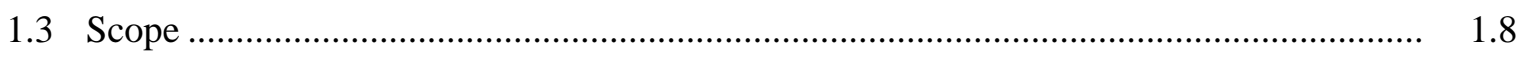

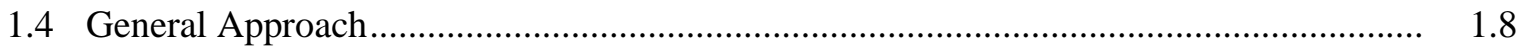

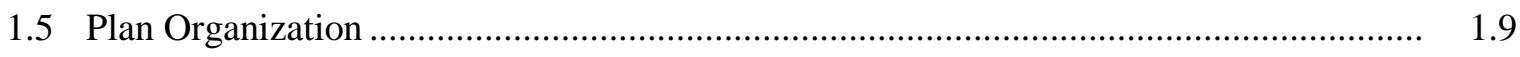

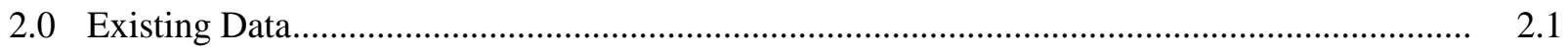

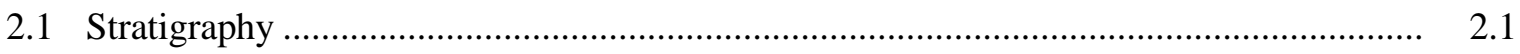

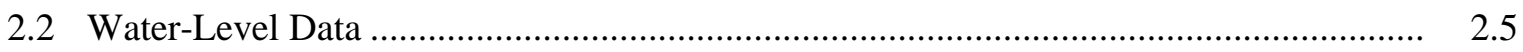

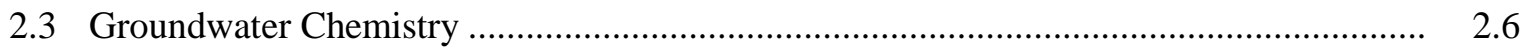

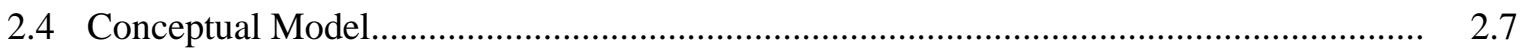

3.0 Groundwater Quality Assessment Program ............................................................... 3.1

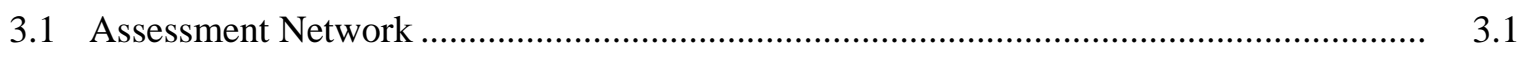

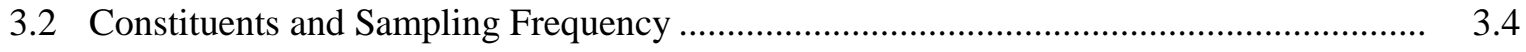

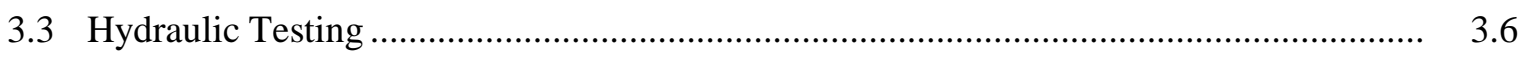

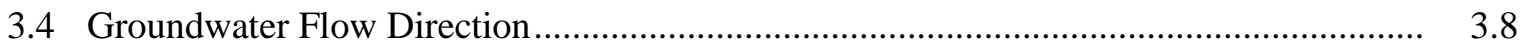

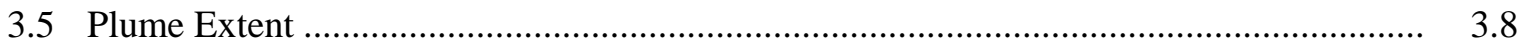

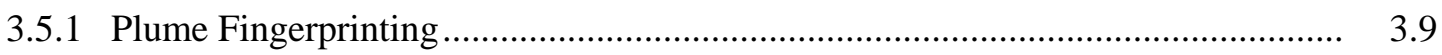

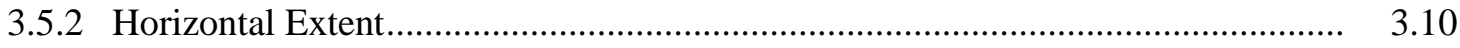

3.5.3 Vertical Extent ............................................................................................ 3.10

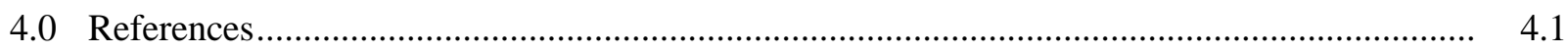


Appendix A - Sampling and Analysis

Appendix B - Well Construction and Completion Summaries

Appendix C - Monitoring Efficiency Model Output Regarding New Well Installation

Appendix D - Preliminary Results for FY-99 and FY-00 Detailed Hydrologic Characterization

Tests Conducted in the WMA S-SX, TX-TY, and T

\section{Figures}

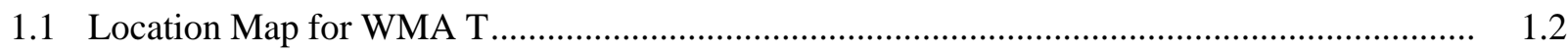

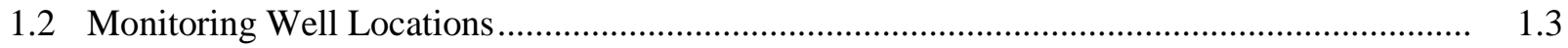

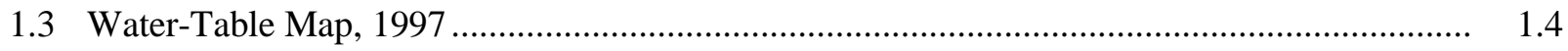

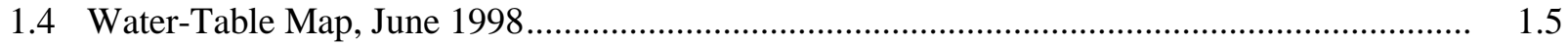

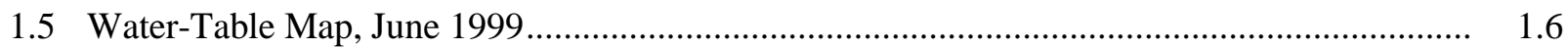

2.1 Generalized Stratigraphic Column for the Hanford Site .................................................... 2.2

2.2 Cross-Section Through RCRA Monitoring Wells at WMAs and TX-TY Showing Geologic and Gross Gamma Logs .............................................................................. 2.3

2.3 Hydrographs for RCRA Monitoring Wells at WMA T ...................................................... 2.5

2.4 Technetium-99 Activities in Monitoring Wells 299-W11-27 and 299-W11-23...................... 2.7

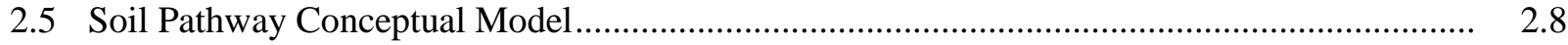

3.1 Locations of Wells in Assessment Network ..................................................................

3.2 Proposed New Well Locations for WMA T ..................................................................... 3.5 


\section{Tables}

3.1a Assessment Monitoring Network, Constituent List and Sampling Frequency for WMA T.

3.1b Additional Assessment Wells, Constituent List, and Sample Frequency Planned for WMA T in Calendar Year 2001

3.2 Analytical Constituents for WMA T...... 


\subsection{Introduction}

Waste Management Area (WMA) T, containing the T Tank Farm, is located in the northern portion of the 200 West Area (Figure 1.1) and is used for the interim storage of radioactive waste from chemical processing of reactor fuel for plutonium production. The WMA, regulated under Resource Conservation and Recovery Act of 1976 (RCRA) interim status regulations was placed in assessment monitoring in 1993 in accordance with 40 CFR Part 265, Subpart F, and by reference of Washington Administrative Code (WAC) 173-303-400(3), because of elevated specific conductance, a RCRA indicator parameter, in one downgradient well. A draft plan was issued in January 1999, which guided work performed in fiscal year 2000. This document supersedes the draft plan for continued RCRA groundwater quality assessment of WMA T as required by 40 CFR 265.93 (d)(7). Pacific Northwest National Laboratory ${ }^{(a)}$ conducted the $^{2}$ assessment.

\subsection{Background}

A detection level RCRA groundwater monitoring program for WMA T was initiated in 1989 (Jensen et al. 1989; Caggiano and Goodwin 1991). The locations of groundwater monitoring wells in the RCRA monitoring network for WMA T are shown in Figure 1.2. The WMA was placed into assessment monitoring in 1993 because specific conductance values in downgradient well 299-W10-15 exceeded the upgradient background value (critical mean) of $1,175 \mu \mathrm{S} / \mathrm{cm}$ (Caggiano and Chou 1993). A water-table map, based on June 1997 measurements, showing the location of wells in the RCRA detection monitoring network is presented in Figure 1.3. Water-table elevations in the vicinity of WMA T and TX-TY have been strongly affected by reduction in wastewater discharge and more locally by the 200-ZP-1 pump-andtreat activity (DOE 2000), as indicated by the dramatic changes in the water-table elevation contours after 1997 south of WMA TX-TY (Figures 1.4 and 1.5).

Elevated specific conductance values in well 299-W10-15, principally a result of elevated sodium and nitrate from an upgradient source, dropped below the critical mean in 1994. However, before the WMA could be returned to a detection level monitoring program, specific conductance in well 299-W11-27 started a rapid increase in late 1995 and exceeded the critical mean in early 1996. In the case of well 299-W11-27, the increased specific conductance was accompanied by elevated technetium-99, tritium, nitrate, calcium, magnesium, sulfate, chromium, cobalt-60, and total organic carbon. In February 1997, technetium-99, the principal contaminant, reached a maximum concentration of 21,700 pCi/L, 24 times the drinking water standard of $900 \mathrm{pCi} / \mathrm{L}$.

The first determination (Hodges 1998) did not identify an upgradient source for the contamination observed in monitoring well 299-W11-27, and indeed found evidence linking the contaminants in groundwater to the WMA. Accordingly, continuation of the groundwater assessment is required. The plan described here implements this RCRA requirement [40 CFR 265.93 (d)(7)].

\footnotetext{
(a) Pacific Northwest National Laboratory is operated by Battelle for the U.S. Department of Energy under Contract DE-AC06-76RL01830.
} 


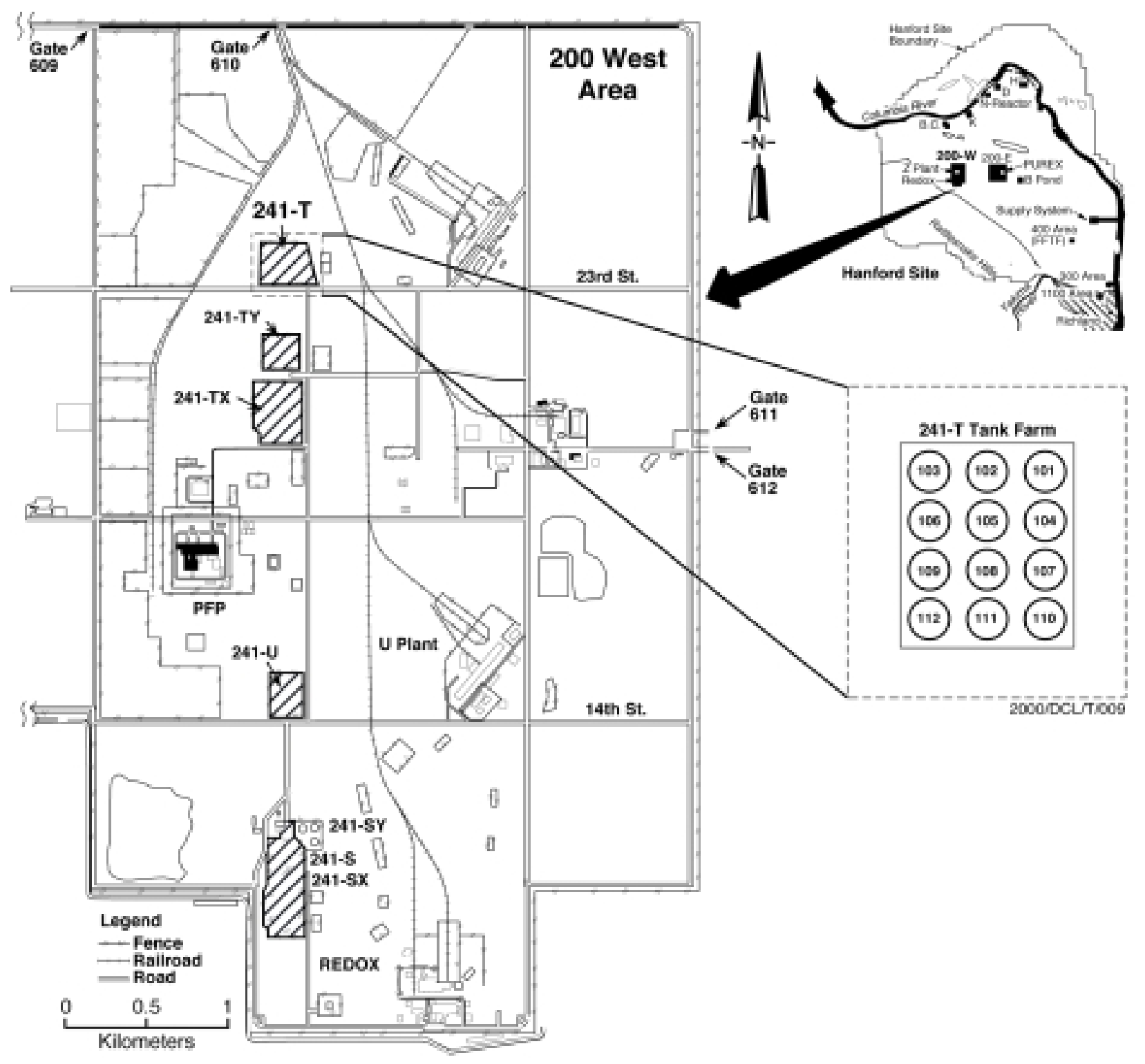

Figure 1.1. Location Map for WMA T 


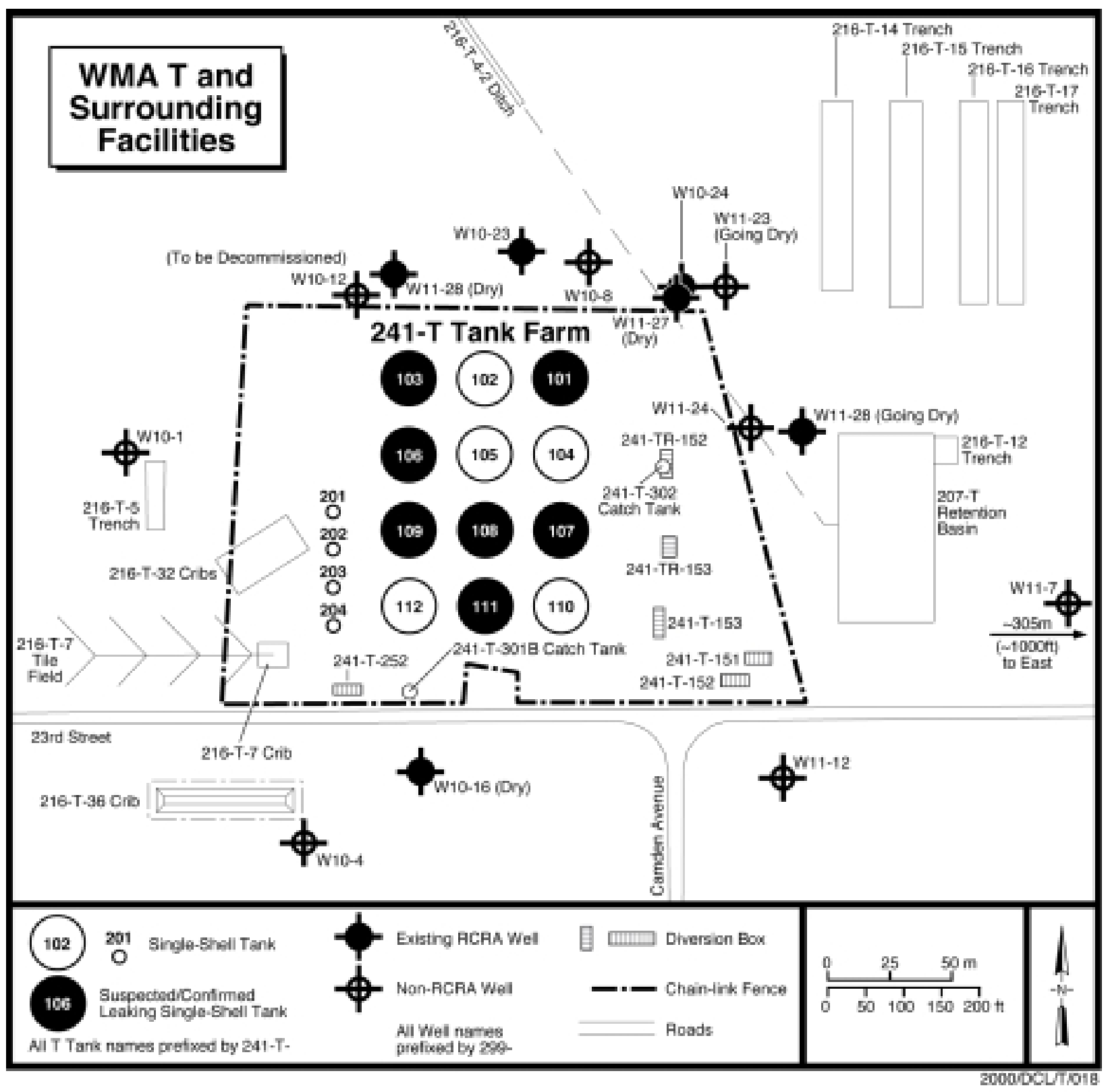

Figure 1.2. Monitoring Well Locations 


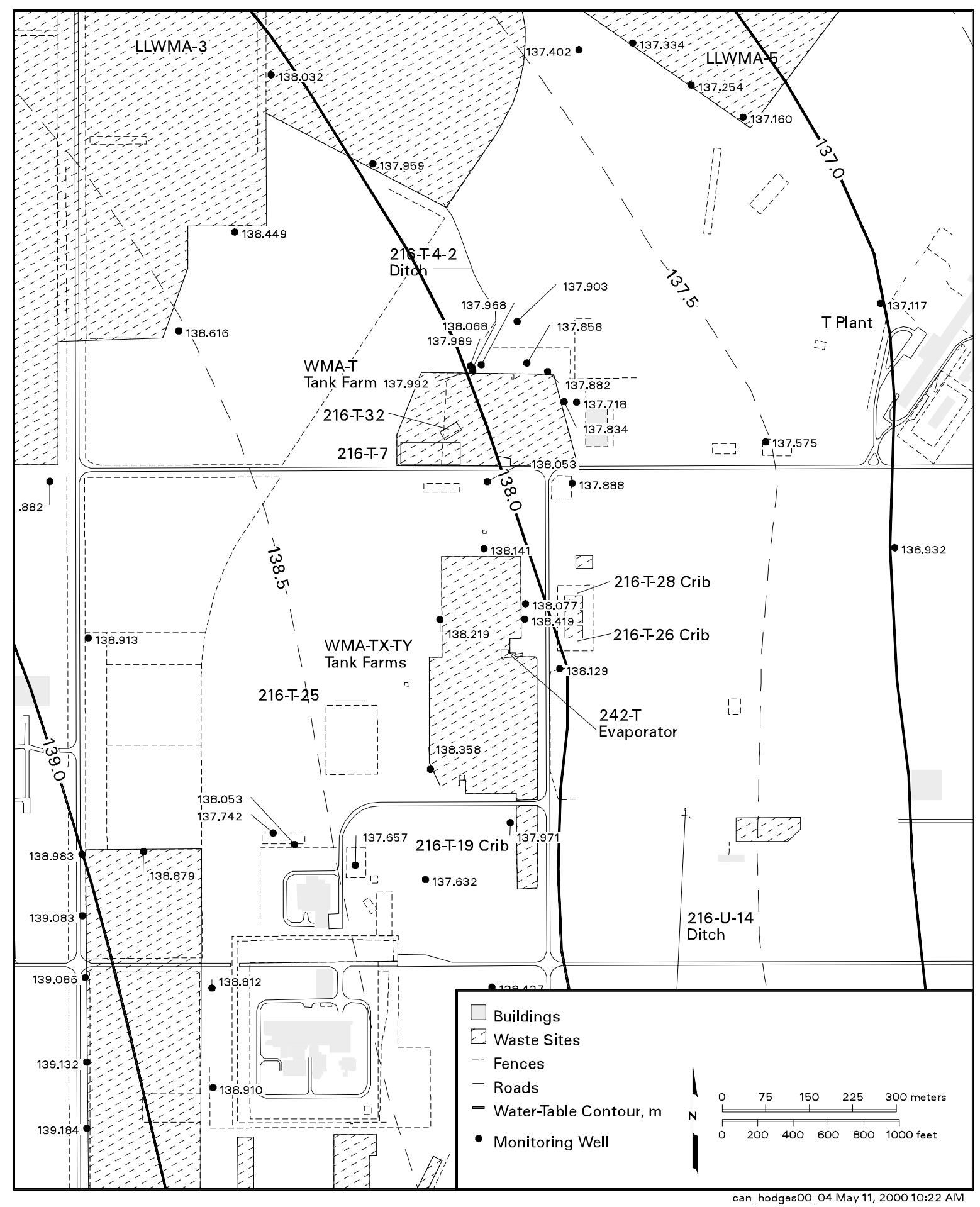

Figure 1.3. Water-Table Map, 1997 


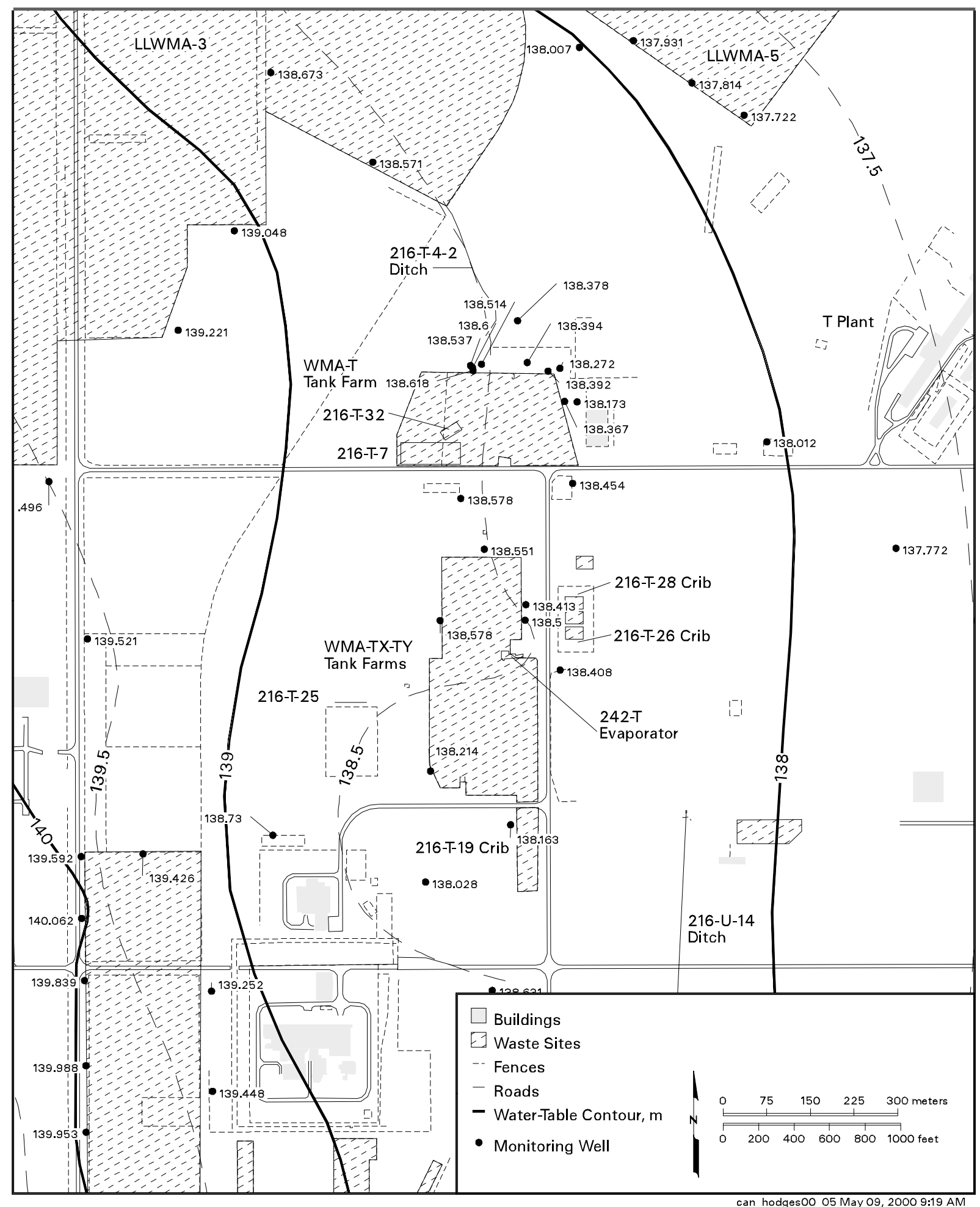

Figure 1.4. Water-Table Map, June 1998 


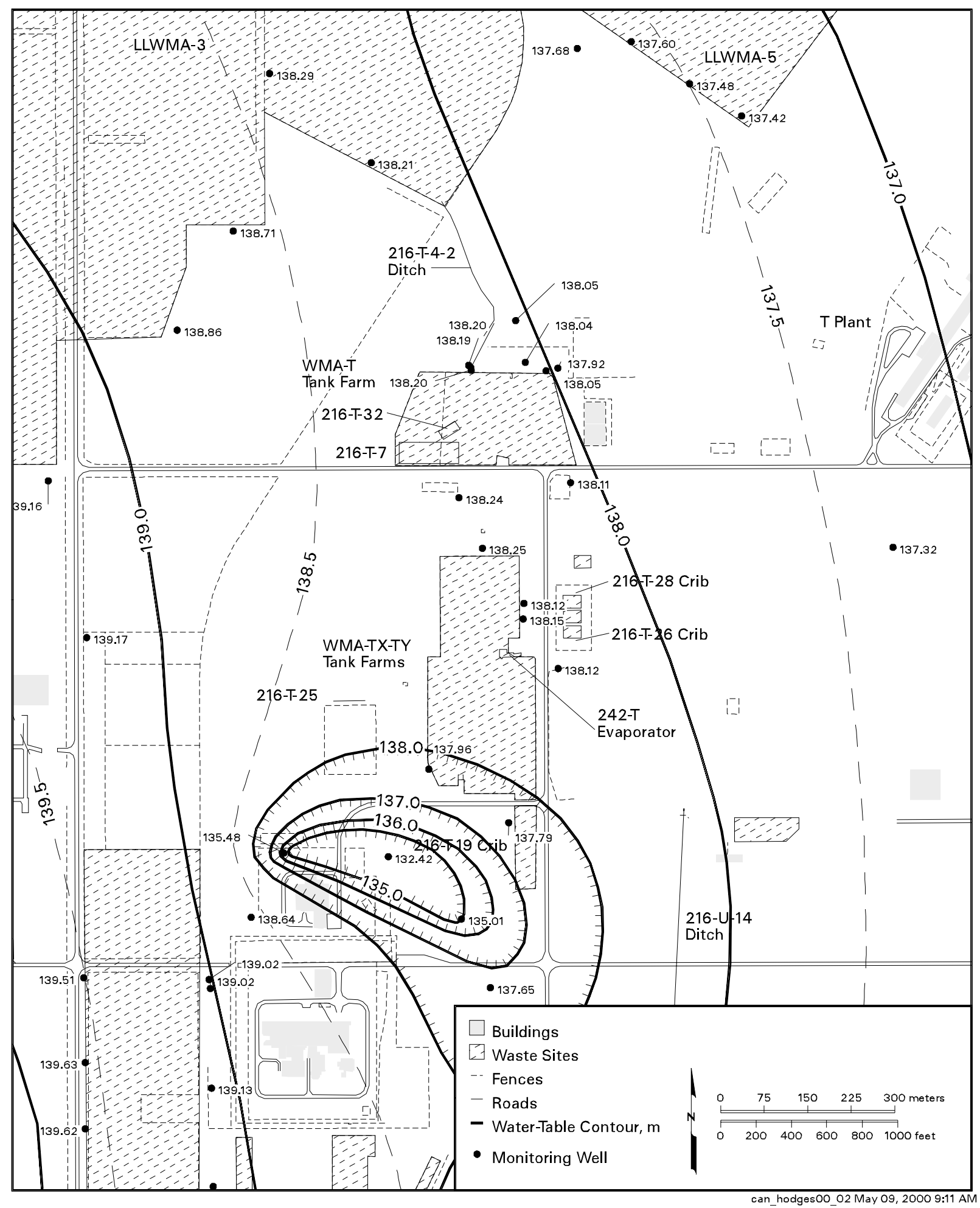

Figure 1.5. Water-Table Map, June 1999 
As one outcome of the first determination (Hodges 1998), a RCRA Facility Investigation/Corrective Measures Study (RFI/CMS) will be initiated at WMA T. The primary focus is on characterization of the nature and extent of vadose zone contamination and assessment of data collected to date to identify initial activities to minimize intrusion and contaminant migration to groundwater. The schedule and activities for the RFI/CMS are described in the Hanford Federal Facility Agreement and Consent Order (Tri-Party Agreement, Ecology et al. 1998), Change Request M-45-98-03. In accordance with the agreement between the U.S. Department of Energy (DOE), and the Washington State Department of Ecology (Ecology) concerning this change request, the continuing RCRA groundwater quality assessment and the RFI/CMS work will be conducted under separate but coordinated plans. Integration of the groundwater quality assessment with the RFI/CMS will be accomplished through the Data Quality Objectives process for the Phase 1 RFI/CMS Work Plan addenda for WMA T and WMA TX-TY, due in December 2000 (milestone M-45-54). Data from the RCRA groundwater quality assessment will be used in RFI/CMS planning and will be included either by reference or directly with the vadose zone data from the RFI/CMS efforts in a field investigation report due June 2003 (milestone M-45-55-T03).

\subsection{Objectives}

The objectives for the continued assessment of groundwater quality at WMA T, as required by 40 CFR 265.93(d)(7)(i), are to determine

(i) the rate and extent of migration of the hazardous waste or hazardous waste constituents in the groundwater

(ii) the concentration of hazardous waste or hazardous waste constituents in the groundwater.

These objectives are related to the remedial investigation of the vadose zone for the RFI/CMS at WMA T. For example, results from both the groundwater and vadose zone are needed to assess the potential near-term risk (risk assessment) associated with hypothetical exposure pathways (DOE/RL99-36). The RFI/CMS process will be used to determine the potential need for interim or corrective measures. The process will proceed incrementally. If there is a determination of substantial risk based on both the groundwater and vadose zone results, a decision to acquire additional data may be made or more immediate near-term mitigating actions may be taken (DOE/RL-99-36). Evaluation of risks associated with existing soil and groundwater contamination will serve the following purposes:

- establish the need for additional interim or corrective measures

- provide input to Hanford site-wide cumulative risk assessments

- serve as a basis to begin identifying cleanup standards (DOE/RL-99-36).

The endpoint for both the soil and groundwater investigations will be decided by Ecology using the risk assessment results. 
Key questions related to the above objectives are as follows:

1. What is the vertical and horizontal concentration profile of all hazardous waste constituents in the plume(s) released from WMA T?

2. What is the rate and extent of contaminant migration in the groundwater?

3. What are the likely sources or source areas for observed groundwater contamination?

4. What are the likely driving forces for observed groundwater contamination?

5. What is the groundwater flow direction?

The groundwater quality assessments for the single-shell tank WMAs are conducted by PNNL for DOE. Also, in accordance with the cleanup objective for Hanford Site tank farms, the groundwater investigations will be planned and implemented to support decisions on interim measures, corrective measures, waste retrieval, and eventual closure of the tank farms.

\subsection{Scope}

The scope of this plan is to acquire the necessary groundwater data to determine the vertical and areal extent of groundwater contamination, contaminant concentrations, and the rate of migration of contaminants originating from the WMA T. In addition, work conducted under the plan will provide information for the RFI/CMS to be conducted at this WMA. Accordingly, the areal study boundary for this plan is the same study boundary as described for the RFI/CMS at WMA T (Change Request M-45-98-03, Attachment One). This consists of the fenced area within the T Tank Farm as well as ancillary structures, such as cribs and transfer lines, etc. adjacent to the fenced area. The vertical extent is defined by the bottom of the aquifer ( $\sim 56 \mathrm{~m}$ [184 ft] thick) contained within the semi-cemented sands and gravels of the Ringold Formation.

\subsection{General Approach}

The general approach to meet the specific or immediate objectives for the continued assessment (i.e., to determine the concentration, rate of movement, and extent of contamination) includes the following major components:

- Determine optimum locations for new monitoring wells to improve the probability of detecting contaminant plumes from the WMA. A combination of well network design modeling and observational inferences will be used for this purpose. A reliable detection network is also important to demonstrate the effectiveness of any interim corrective measures undertaken as a result of the $\mathrm{RFI} / \mathrm{CMS}$ process. 
- Determine depth distribution of contaminants within the aquifer by discrete depth sampling during drilling of new wells and multi-depth well completions.

- Conduct hydrologic testing on selected wells to obtain estimates of hydraulic conductivity, effective porosity, and preferential flow zones within the screened interval of monitoring wells. This information will be used in concert with new water-level data to determine groundwater flow velocities and to determine optimal locations of sampling intervals within the well screen intervals.

- Use spatial and temporal mapping of the contaminant plumes to delineate the extent and concentration of contaminants and their relationship to potential sources within the study boundary. In concert with hydrogeologic data, estimate the approximate rate and direction of contaminant migration.

- Use ratios between various chemical constituents and isotopes (fingerprinting) to aid the identification of contaminant sources (e.g., cribs versus tanks) affecting groundwater quality. This, in turn, can help narrow the areas of concern for the vadose zone studies to be conducted for the RFI/CMS. This activity will be closely coordinated with the Tank Farm Vadose Zone Project activities, which include reconstruction of tank waste inventories over time based on tank transfer and disposal history.

The above efforts will lead to

- improved knowledge of the direction and velocity of groundwater flow

- a better understanding of the location and areal and vertical extent of contaminant plume(s) in the vicinity of WMA T

- enhanced understanding about the sources and characteristics of the groundwater contamination

- recommendations for effective placement of new monitoring wells.

\subsection{Plan Organization}

In addition to this introduction, a review of existing data including stratigraphy, water-level data, groundwater chemistry, and conceptual model development is presented in Chapter 2.0. A description of the groundwater monitoring program including evaluation of the assessment network, constituent lists and sample frequency, hydraulic testing, groundwater flow direction, and plume extent are presented in Chapter 3.0. The references cited in the text are given in Chapter 4.0. The sampling and analysis plan is included as Appendix A. Geologic cross-sections and as-built drawings of the existing RCRA and nonRCRA monitoring wells that will be used in the investigative activities are included in Appendix B. Results from the spatial modeling effort (e.g., Monitoring Efficiency Model as documented in [Wilson et al. 1992]) are included in Appendix C. Preliminary results obtained from detailed hydrologic characterization tests within the WMA are presented in Appendix D. 


\subsection{Existing Data}

This section summarizes existing stratigraphic, hydrologic, and groundwater chemistry data within and in the vicinity of WMA T. Most of this information is derived from RCRA and/or earlier non-RCRA groundwater monitoring wells. An extensive data set exists for the four RCRA-compliant wells (299 W10-16, 299-W10-15, 299-W11-27, and 299-W11-28) that were part of the original detection level monitoring network. Wells 299-W10-16 (upgradient), 299-W10-15, and 299-W11-27 went dry; well 299-W11-28 is going dry. In calendar year 1998, two wells, 299-W10-23 and 299-W10-24, were drilled to replace wells 299-W10-15 and 200-W11-27, respectively. Eight non-RCRA wells (299-W10-1, 299 W10-12, 299-W10-8, 299-W11-23, 299-W11-24, 299-W11-12, 299-W10-4 and 299-W11-7) were added to the extended assessment monitoring network. However, data for other wells in the area are sparse or non-existent. One of the goals of this assessment is to provide a viable database for water levels and groundwater chemistry in the larger area around the WMA. This information will aid the understanding of hydrogeologic conditions at the WMA and aid in tracking the movement of contaminant plumes.

\subsection{Stratigraphy}

WMA T is underlain by approximately $152 \mathrm{~m}(500 \mathrm{ft})$ of suprabasalt sediments, based on the stratigraphy in well 299-W11-26 (DH-6), reported by Lindsey (1995). The suprabasalt sediments consist of

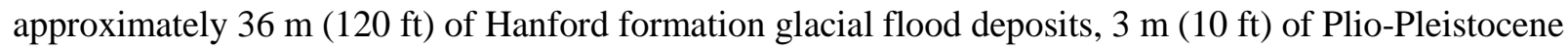

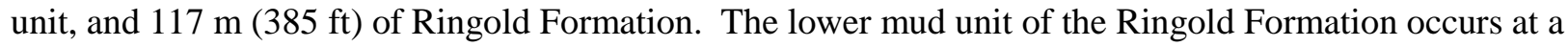
depth of $126 \mathrm{~m}(412 \mathrm{ft})$ and, where it is locally confining, the unconfined aquifer has a thickness of approximately $52 \mathrm{~m} \mathrm{(170} \mathrm{ft)} \mathrm{and} \mathrm{is} \mathrm{contained} \mathrm{entirely} \mathrm{within} \mathrm{unit} \mathrm{E} \mathrm{of} \mathrm{the} \mathrm{Ringold} \mathrm{Formation.} \mathrm{The} \mathrm{water}$ table beneath the WMA occurs at a depth of approximately $70 \mathrm{~m}(230 \mathrm{ft})$, thus, the unconfined aquifer beneath the WMA has a thickness of approximately $56 \mathrm{~m}(184 \mathrm{ft})$.

The Hanford formation consists of gravels, sands, and silts deposited by catastrophic glacial floods at the end of the Pleistocene. The Hanford formation sediments are clast supported, uncemented, and highly permeable to both liquid and gases. At WMA T, they are contained entirely within the vadose zone. The Plio-Pleistocene unit is a sandy, silty carbonate cemented (caliche) paleosol that occurs at the top of the Ringold Formation. It is present throughout the 200 West Area and forms an extensive, but imperfect, barrier to vertical migration within the vadose zone. The Ringold Formation, in the vicinity of WMA T, consists of fluvial sediments deposited by the ancestral Columbia River. It is dominated by two gravel packages, unit $\mathrm{E}$ above a fine gained unit, the lower mud unit, and unit $\mathrm{A}$ between the lower mud unit and the top of basalt. Gravels within unit E, which contains the unconfined aquifer beneath the WMA, are characterized by highly variable cementation. As a result of this irregular cementation, highly variable hydraulic conductivities and preferred flow zones likely occur within the aquifer. A generalized stratigraphic column for the Hanford Site is presented in Figure 2.1.

A north-south cross-section through WMA T and TX-TY, based on geologic and geophysical logs from existing RCRA monitoring wells, is presented in Figure 2.2. 


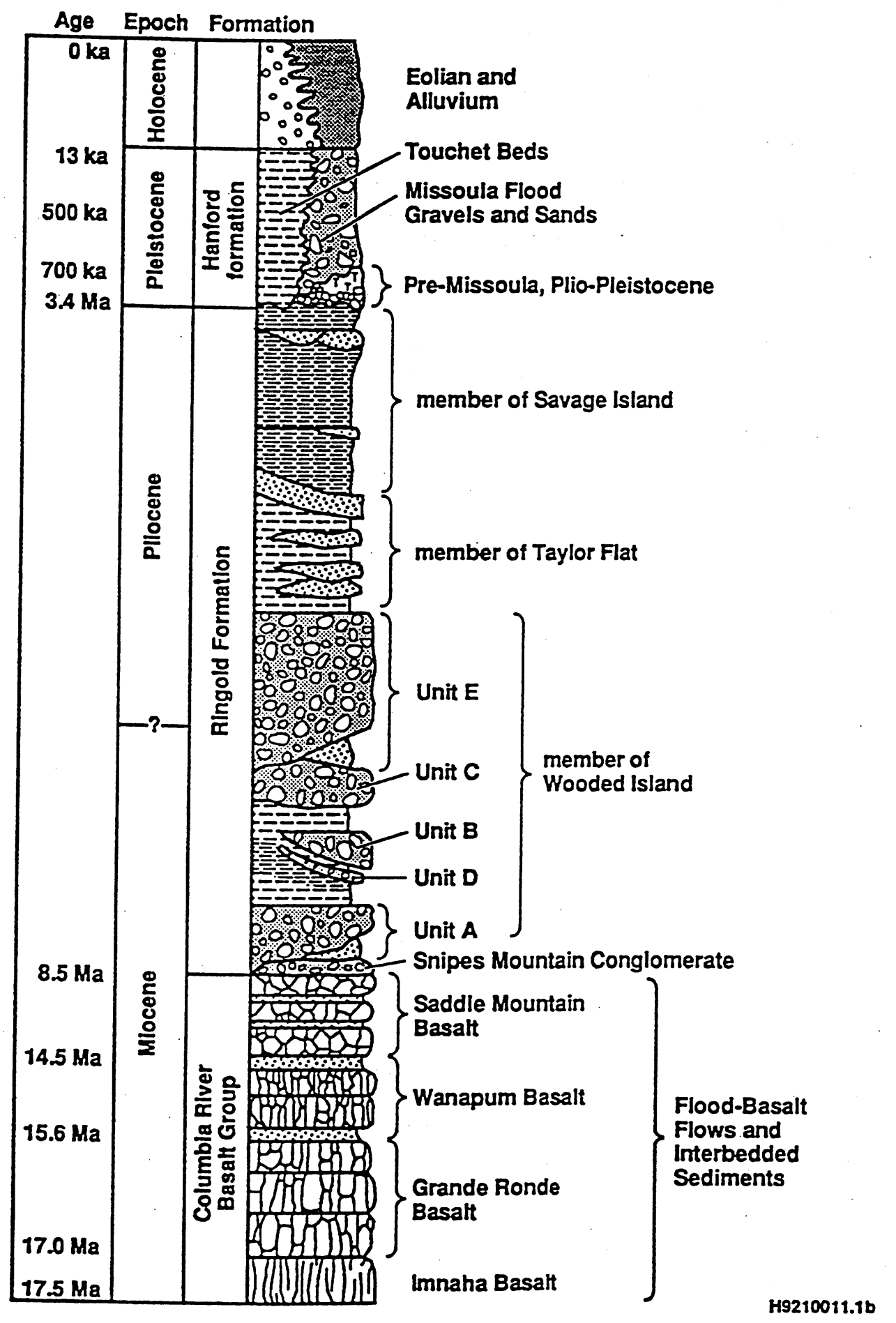

Figure 2.1. Generalized Stratigraphic Column for the Hanford Site (Lindsey 1995). Column emphasizes Ringold Formation and is not to scale. 
T Farm

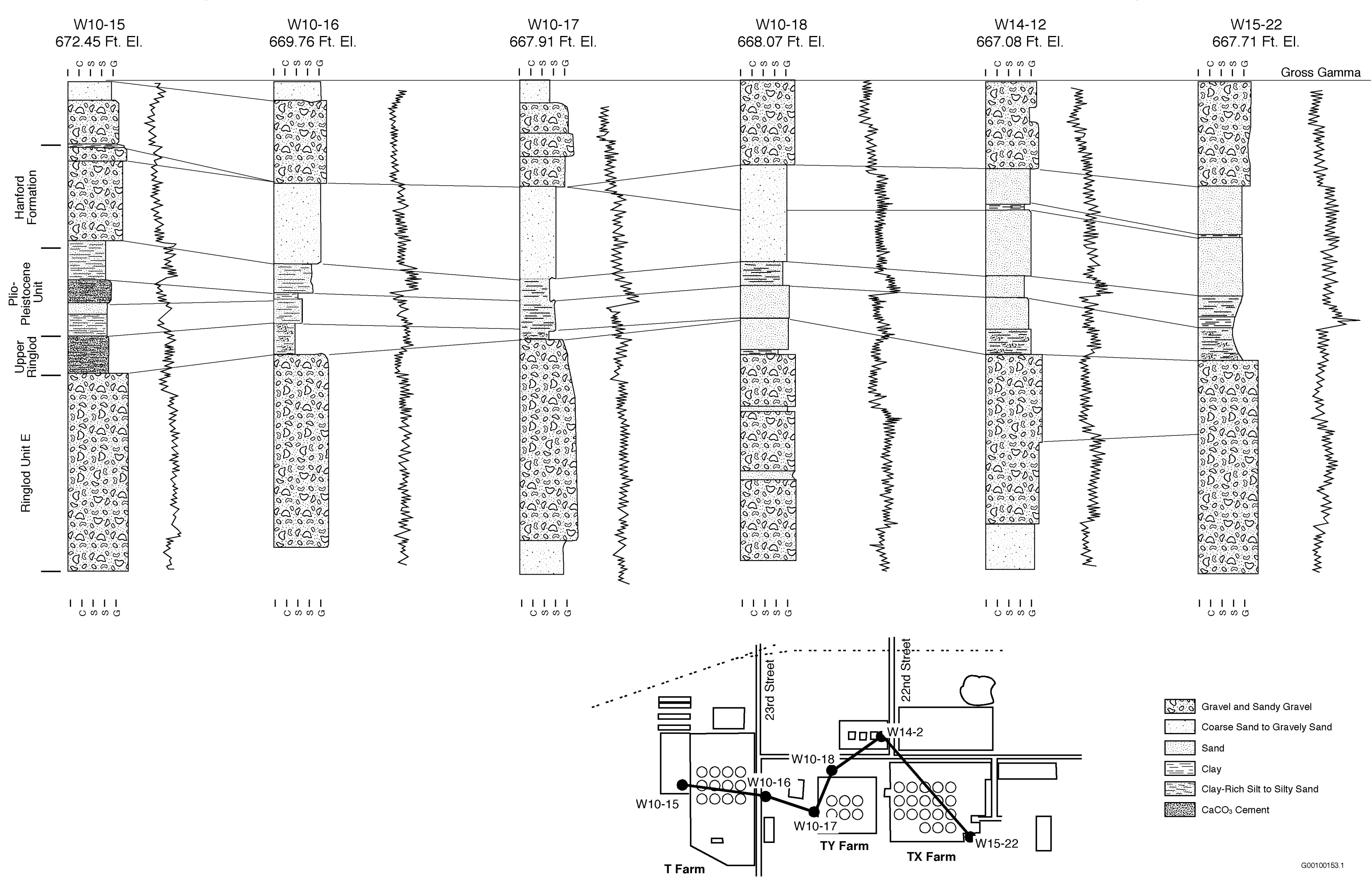

Figure 2.2. Cross-Section Through RCRA Monitoring Wells at WMAs and TX-TY Showing Geologic and Gross Gamma Logs 


\subsection{Water-Level Data}

Water levels have declined beneath the WMA since the inception of RCRA monitoring in 1989 (Figure 2.3). This decline, resulting from decreasing effluent discharge in the $200 \mathrm{West}$ Area, became much steeper in 1995 with the effective cessation of discharge to ground in this area. The rapid decrease in water levels after 1995 has resulted in monitoring wells going dry more quickly than previously predicted and has necessitated the drilling of new monitoring wells.

Groundwater flow directions in the vicinity of WMA T have been highly variable because of changing effluent discharge sites within the 200 West Area (Hodges 1998). At the time the RCRA detection network was established, the direction of groundwater flow was toward the northeast (Caggiano and Goodwin 1991). However, effluent discharges within the 200 West Area have declined in magnitude and stopped entirely in 1995. This caused the direction of groundwater flow to move to a more easterly direction, which is believed to be the direction of groundwater flow prior to the establishment of the Hanford Site. During 1998, this change in the direction of groundwater flow accelerated (see Figure 1.4).

Whether the direction of groundwater flow will stabilize in an easterly direction, or will continue to rotate toward the southeast, is uncertain. Another variable is the high cementation within the Ringold Formation. Thus, locally, there may be preferred flow paths that differ from the general flow direction indicated by the water-table maps.

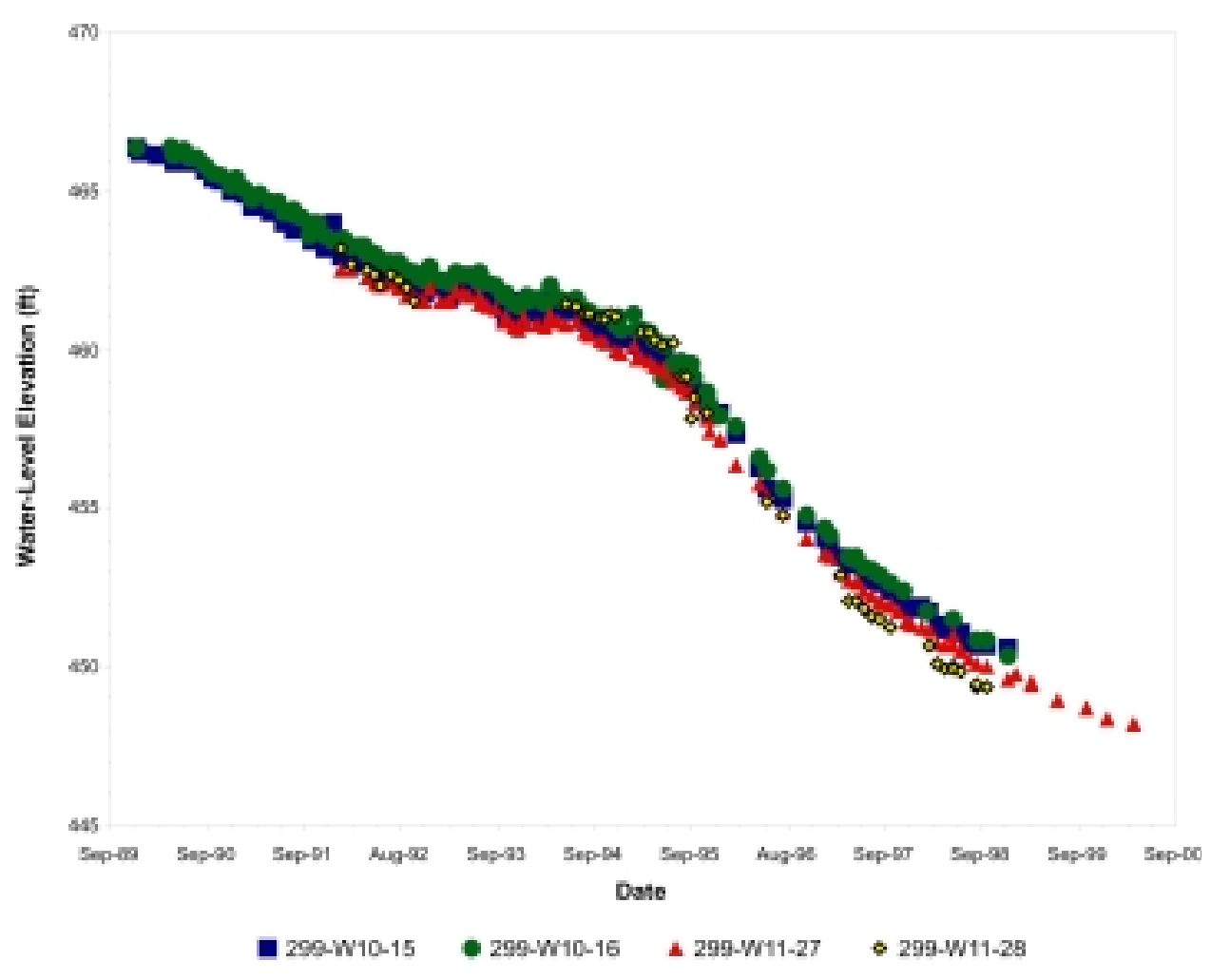

Figure 2.3. Hydrographs for RCRA Monitoring Wells at WMA T 


\subsection{Groundwater Chemistry}

Groundwater chemistry in the vicinity of WMA T is dominated by high sodium, high nitrate groundwater containing varying concentrations of tritium, technetium-99, and other contaminants. These contaminants are a result of 50 years of waste management activities in the 200 West Area. In fact, the WMA was originally placed in assessment because of variations of specific conductance in background groundwater as it affected well 299-W10-15 (Caggiano and Chou 1993, Hodges 1998). In contrast, groundwater northeast of the WMA has very low ionic strength. This water is essentially contaminant free, possibly a result of leaks from a transfer line taking $\mathrm{T}$ Plant effluent (primarily cooling water) from the 207-T Retention Basin to the 216-T-4-2 Ditch as discussed below.

Prior to 1995 , contour maps showed a localized area of very low specific conductance $(<250 \mu \mathrm{S} / \mathrm{cm})$ area near the northeast corner of T Tank Farm. However, a large area west of WMA T and extending east across WMA T showed high specific conductance $(\sim 1,000 \mu \mathrm{S} / \mathrm{cm})$ (see Figure 3.6, Hodges 1998). Columbia River water, the source of Hanford Site makeup water, has a specific conductance of about $140 \mu \mathrm{S} / \mathrm{cm}$. Thus, the very localized zone of low conductivity water was attributed to a leaking wastewater line in this area that was used to transfer cooling water to the 216 T-4-2 Ditch. In late 1995, following termination of surface discharges within the 200 West Area, downgradient well 299-W11-27, located at the northeast comer of WMA T, experienced a rapid increase in specific conductance, technetium-99, chromium and other contaminants. In February 1997, technetium-99 reached a maximum of $21,700 \mathrm{pCi} / \mathrm{L}$ (drinking water standard $=900 \mathrm{pCi} / \mathrm{L}$ ). In late 1997 , the contaminants affecting well 299-W11-27 reached downgradient well 299-W11-23 (Figure 2.4). Apparently the localized groundwater mound from the leaking wastewater transfer line diverted the contaminant plume away from the monitoring well(s) or pushed it down below the screened interval of well 299-W11-27. When the discharges to ground were terminated in 1995, the mound dissipated and the monitoring wells could then intercept the contaminant plume from T Tank Farm.

Sampling during drilling at well 299-W10-24 (WMA T) and 299-W14-14 (WMA TX-TY), drilled through the Ringold lower mud unit, indicate contamination with carbon tetrachloride, tritium, and technetium-99 throughout the thickness of the aquifer, and below the lower mud unit. Contaminant concentrations tend to peak at depths of 30 to $45 \mathrm{~m}(\sim 100$ to $150 \mathrm{ft})$ beneath the water table, however they are present in significant concentrations at all depths that were sampled.

The direction of groundwater flow at WMA T is complex, and there are multiple potential sources of groundwater contamination in the area. Therefore, a means is needed to distinguish one source type from another. One approach is to use elemental and isotopic ratios of mobile groundwater constituents as indicators to differentiate tank from crib sources. These ratios also may be used to define mixing lines for varying groundwater compositions (Hodges 1998). Contaminant concentrations can vary widely from the centerline of a plume to the outer edges. However, the ratio of two mobile constituents associated with the plume will not change (assuming the plume in question is the only source of the two constituents). Variation in the ratios (systematic deviation from a single or narrow range of values) of selected contaminant concentrations could be attributed to different source types. For example, the sodium/calcium ratio could provide useful information to discern between different sources. Other useful ratios include tritium/ technetium-99, and nitrate/technetium-99. 


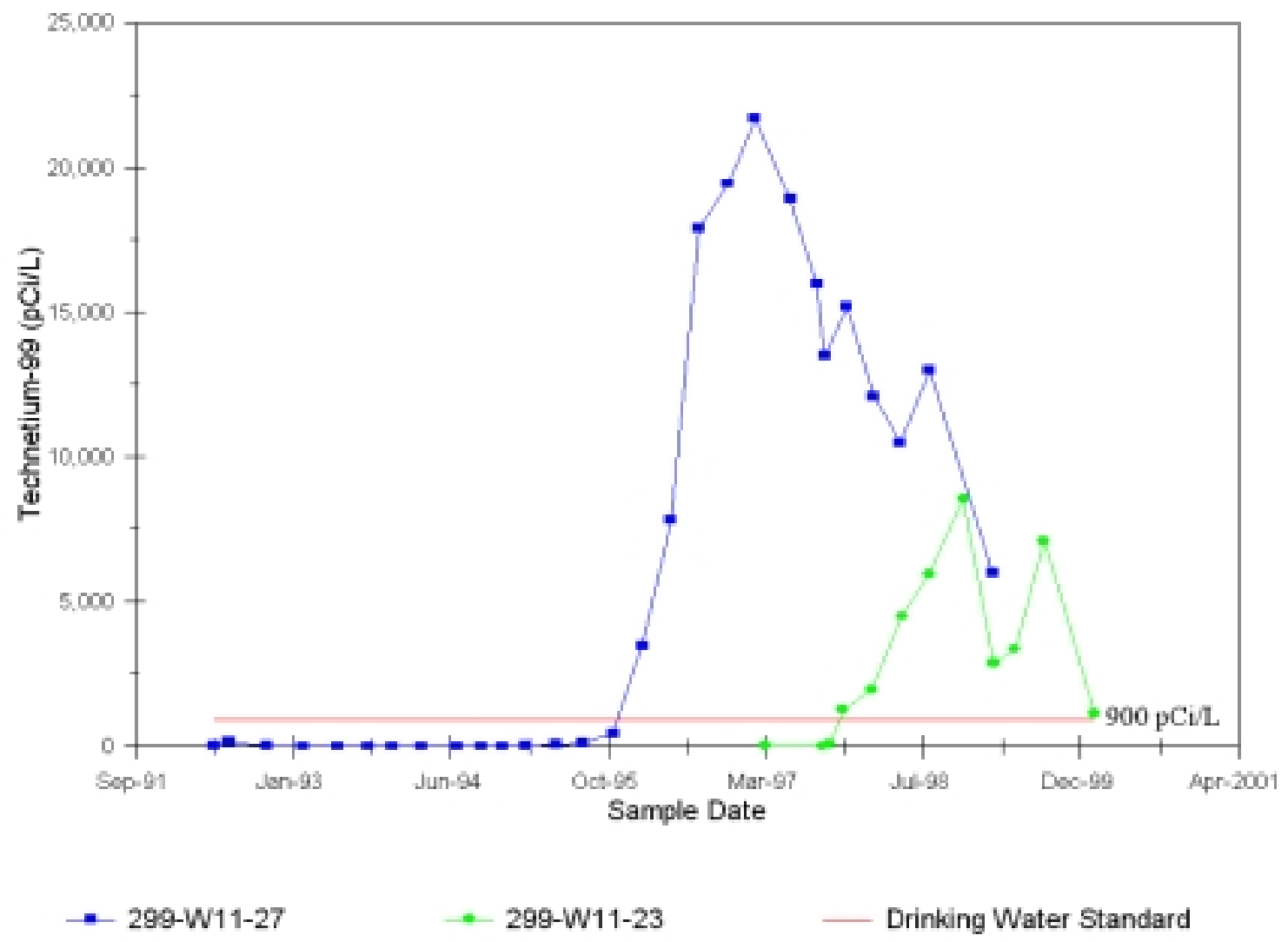

Figure 2.4. Technetium-99 Activities (pCi/L) in Monitoring Wells 299-W11-27 and 299-W11-23

\subsection{Conceptual Model}

Conceptual models are essentially collections of working hypotheses that provide a framework for ongoing work. This framework should be continually modified as new data become available and new understanding is developed.

Figure 2.5, taken from Johnson and Chou (1998), is a reasonable representation or first approximation of possible pathways to groundwater in the 200 West Area. Sources of contamination include tank leaks, tank overflows, junction box or transfer line leaks, and in the case of WMA T, cribs and part of a tile field included within the WMA boundaries. Although seven tanks within WMA T are known or suspected leakers, the major potential leak source is associated with tank T-106 that leaked an estimated $4.34 \times 10^{5}$ L (115,000 gal) of tank supernate (Routson et al. 1979). In addition, a tank overflow event at tank T-101 prior to 1974 may have released a volume of waste comparable to the T-106 leak (Routson 1981).

Driving forces for moving waste through the vadose zone consist principally of gravel-enhanced infiltration of normal precipitation (Gee et al. 1992) and the effects of flooding during rapid snow melt events (Hodges 1998, Figure 3.23). Water lines within the T Tank Farm are generally lacking and do not represent the type of problem presented at WMA S-SX (Johnson and Chou 1998); however, it is possible 


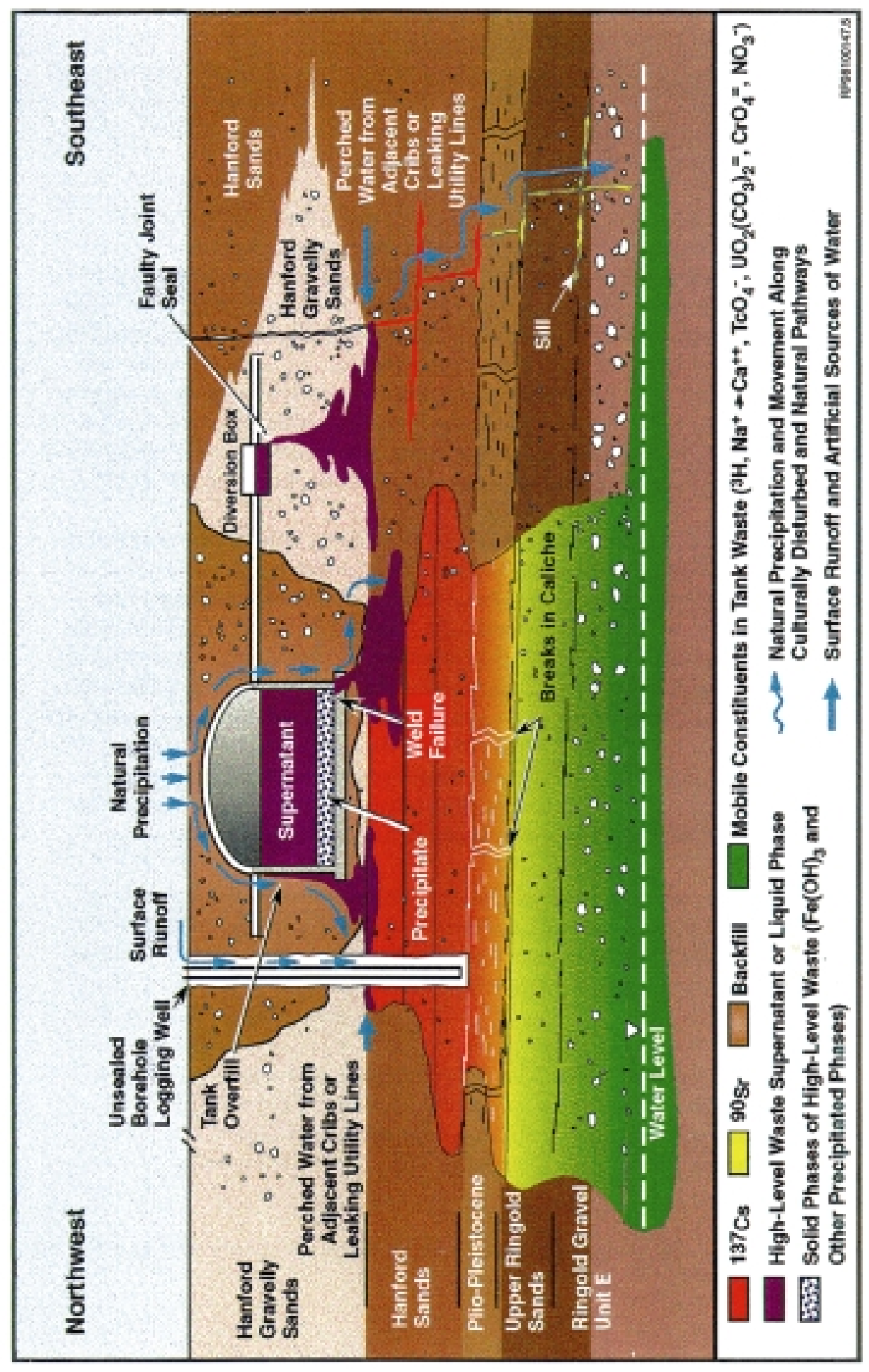

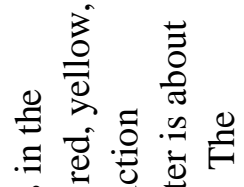

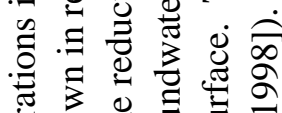

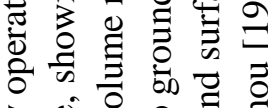

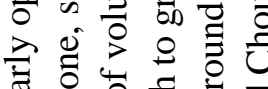
छึ 웅

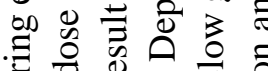

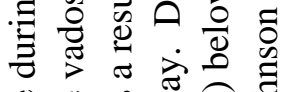
\& 䒕

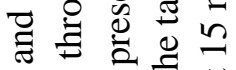

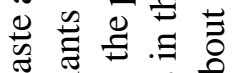
$3 . \Xi$ ตे तै 芩芯 壳芯

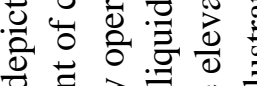

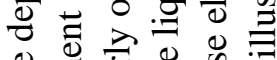

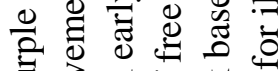
ప ఏ ఏ 过

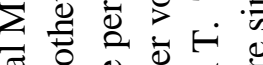
胥苍总志 웡 $\Xi \sum^{\vdots}$ ठี ن ते

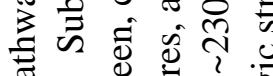

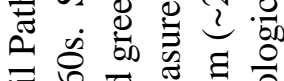
:

in 
that water from the pipeline along the northeastern corner of the WMA migrated down along the top of the calcite cemented Plio-Pleistocene unit (caliche layer) and mobilized waste in the vadose zone beneath the WMA.

Previous investigations of tank leaks at tanks SX-108 and T-106 (Serne et al. 1998, Freeman-Pollard et al. 1994), suggested that most of the contaminants remained high in the soil column. One hypothesis proposed to account for this observation involves both sorption and plugging of the pore spaces in the soil with silica and alumina gels or precipitates released through reaction of highly alkaline waste and silicate minerals in the soil column (Serne et al. 1998). Thus, on the basis of the two studies cited, there was not a general downward migration of contaminants, particularly cesium-137, strontium-90 or transuranics. However, these studies are not conclusive concerning the fate of more mobile constituents and groundwater evidence indicates that pathways do exist.

Regardless of the pathway through the vadose zone, when tank waste reaches the water table it may sink or form a layer at the top of the aquifer depending on the density of the waste and its arrival rate at the water table, relative to the rate of groundwater flow. Hanford tank waste is essentially a saturated sodium nitrate brine, and its density is sufficient to allow it to sink through the aquifer if flow rate is too low to facilitate mixing. Waste mobilized by influx of meteoric or other surface water will be diluted and the density will depend on the degree of mixing. An additional complication is relatively clean water that may infiltrate to the water table upgradient and/or downgradient of the point where the contaminants entered groundwater, an effect enhanced by wide gravel aprons around the tanks. Thus, there may be vertical layering in the aquifer resulting from multiple infiltration effects. Determination of the vertical variation of contaminants within the aquifer may aid in determining vadose zone transport mechanisms within the tank farms. 


\subsection{Groundwater Quality Assessment Program}

The initial investigation of groundwater quality conditions at WMA T (Hodges 1998) addressed the basic question of whether or not the WMA was responsible for contributing to groundwater contamination. Because it was concluded that the WMA has affected groundwater (Hodges 1998), the general focus of the continued investigation is to determine the rate and extent of migration of the hazardous constituents or waste constituents in the groundwater and their concentrations [40 CFR 265(d)(4) and by reference WAC 173-303-400(3)]. The requirements under the continued assessment program are more intensive than what is required for RCRA indicator evaluation monitoring. This section presents the groundwater monitoring network (including proposed locations for new wells), sampling frequency, and analytical constituent lists to be used to meet the requirements of assessment monitoring.

\subsection{Assessment Network}

The current assessment network consists of point-of-compliance wells located near the tank farm fence line and one mid-field well (299-W11-7). As a result of the shift in groundwater flow direction to the east, and MEMO model predictions of well coverage efficiency (Appendix C), combined with both judgment and contaminant observations, three new wells as well as one replacement well are proposed to be drilled in calendar year 2000. These new wells will provide a more complete areal coverage to identify potential sources of contamination within the WMA and will help fulfill the requirement to assess the extent of groundwater contamination from this WMA. Existing monitoring wells and the proposed new wells for calendar year 2000 are listed in Table 3.1a. The approximate location of the wells are shown in Figure 3.1. In addition, five wells are planned for calendar year 2001 pending funding availability (Table 3.1b). The proposed well locations are shown in Figure 3.2. One well is an upgradient well, which will replace a non-RCRA well (299-W10-1). Another well is a near-field downgradient well, which will monitor at depth to evaluate contaminant depth distribution near the WMA. Also, two wells (a deep and an intermediate depth well) adjacent to well 1 (calendar year 2000 well, see Figure 3.2) will be drilled for a three well cluster. If contamination is detected at depth in downgradient wells, the results from monitoring wells installed at these locations will be evaluated to determine whether deep upgradient wells will be needed to differentiate possible upgradient sources of the deep contamination. As-built diagrams for the existing assessment network wells are presented in Appendix B.

There is a mid-field deep well to evaluate the horizontal and the vertical extent of contamination. The contaminant plume intercepted by well 299-W11-27 apparently came from within the WMA, and probably from the northern portion of the $\mathrm{T}$ tank farm. When the plume was intercepted at well 299-W11-27, the groundwater flow was generally toward the northeast. With the present groundwater flow toward the east, or slightly north of east, the existing plume should drift eastward across the downgradient wells. Any contaminants entering groundwater beneath the WMA will now form a plume moving toward the east from wherever it originates within the WMA. The contaminant chemistry of groundwater in the new downgradient wells, coupled with better estimates of flow velocities and of aquifer hydraulic properties resulting from tests in the new wells (see Section 3.4) will allow a determination of the best location for this well. 
Table 3.1a. Assessment Monitoring Network, Constituent List and Sampling Frequency for WMA T

\begin{tabular}{|c|c|c|c|c|c|}
\hline Well & $\begin{array}{l}\text { RCRA } \\
\text { Standard }\end{array}$ & $\begin{array}{l}\text { Sampling } \\
\text { Frequency }^{(a)}\end{array}$ & $\begin{array}{l}\text { Constituent } \\
\text { List }^{(\mathrm{b})}\end{array}$ & Co-Sample & Comment \\
\hline \multicolumn{6}{|c|}{ Existing Monitoring Network } \\
\hline 299-W10-1 & $\mathrm{N}$ & Q & A & & \\
\hline 299-W10-12 & $\mathrm{N}$ & Q & A & & To be decommissioned \\
\hline $299-\mathrm{W} 10-23^{(\mathrm{c})}$ & $\mathrm{Y}$ & $\mathrm{Q}$ & A & & 299-W10-15 replacement \\
\hline 299-W10-8 & $\mathrm{N}$ & Q & A & & \\
\hline $299-W 10-24^{(\mathrm{d})}$ & $\bar{Y}$ & $\mathrm{Q}$ & $\mathrm{A}, \mathrm{B}, \mathrm{C}$ & & 299-W11-27 replacement \\
\hline 299-W11-23 & $\mathrm{N}$ & $\mathrm{Q}$ & $\mathrm{A}, \mathrm{B}$ & & Going dry \\
\hline 299-W11-24 & $\mathrm{N}$ & Q & $\mathrm{A}, \mathrm{B}$ & & 299-W11-28 replacement \\
\hline 299-W11-28 & $\mathrm{Y}$ & $\mathrm{Q}$ & $\mathrm{A}, \mathrm{B}$ & & Going dry \\
\hline 299-W11-12 & $\mathrm{N}$ & Q & A & & \\
\hline 299-W10-4 & $\mathrm{N}$ & $\mathrm{Q}$ & A & & 299-W10-16 replacement \\
\hline 299-W11-7 & NA & SA & A & $\mathrm{AEA}^{(\mathrm{e})}$ & Mid-field \\
\hline \multicolumn{6}{|c|}{ New Wells to be Drilled in Calendar Year 2000} \\
\hline Well 1 & $\mathrm{Y}$ & $\mathrm{Q}$ & $\mathrm{A}, \mathrm{B}, \mathrm{C}$ & & \\
\hline Well 2 & $\bar{Y}$ & $\mathrm{Q}$ & $\mathrm{A}, \mathrm{B}$ & & 299-W11-24 replacement \\
\hline Well 3 & $\mathrm{Y}$ & $\mathrm{Q}$ & $\mathrm{A}, \mathrm{B}$ & & \\
\hline Well 4 & $\mathrm{Y}$ & $\mathrm{Q}$ & $\mathrm{A}, \mathrm{B}$ & & \\
\hline \multicolumn{6}{|c|}{$\begin{array}{l}\text { (a) SA = Semiannually; Q = Quarterly; NA = Not applicable } \\
\text { (b) Letters refer to lists in Table } 3.2 . \\
\text { (c) Completed October } 1998 . \\
\text { (d) Completed September } 1998 . \\
\text { (e) Integrated with Atomic Energy Act monitoring activity. }\end{array}$} \\
\hline
\end{tabular}

In addition, some wells may become unusable in the future because of the declining water table and/or changing direction of groundwater flow or being decommissioned. If this happens, the effect on the monitoring network must be re-evaluated and, on the basis of ongoing evaluations, it may be necessary to deepen existing wells, where feasible, and or to drill new wells.

Well 299-W10-24 (well 299-W11-27 replacement) was drilled through the lower mud unit of the Ringold Formation, with groundwater samples collected at discrete intervals within the aquifer, to determine the depth distribution of contaminants. Samples were taken at depths of approximately 15, 30, 46, 58, and $67 \mathrm{~m}(50,100,150,190$, and $220 \mathrm{ft})$ below the water table. The lower two depths provide samples immediately above and below the Ringold lower mud unit, based on the stratigraphy for nearby well 299-W11-26 presented by Lindsey (1995). After sampling, the well was backfilled and completed at the top of the water table with a $10-\mathrm{m}(35-\mathrm{ft})$ screened interval. Results from the discrete depth sampling indicated deeply distributed nitrate, tritium, and carbon tetrachloride. Technetium-99, on the other hand, 


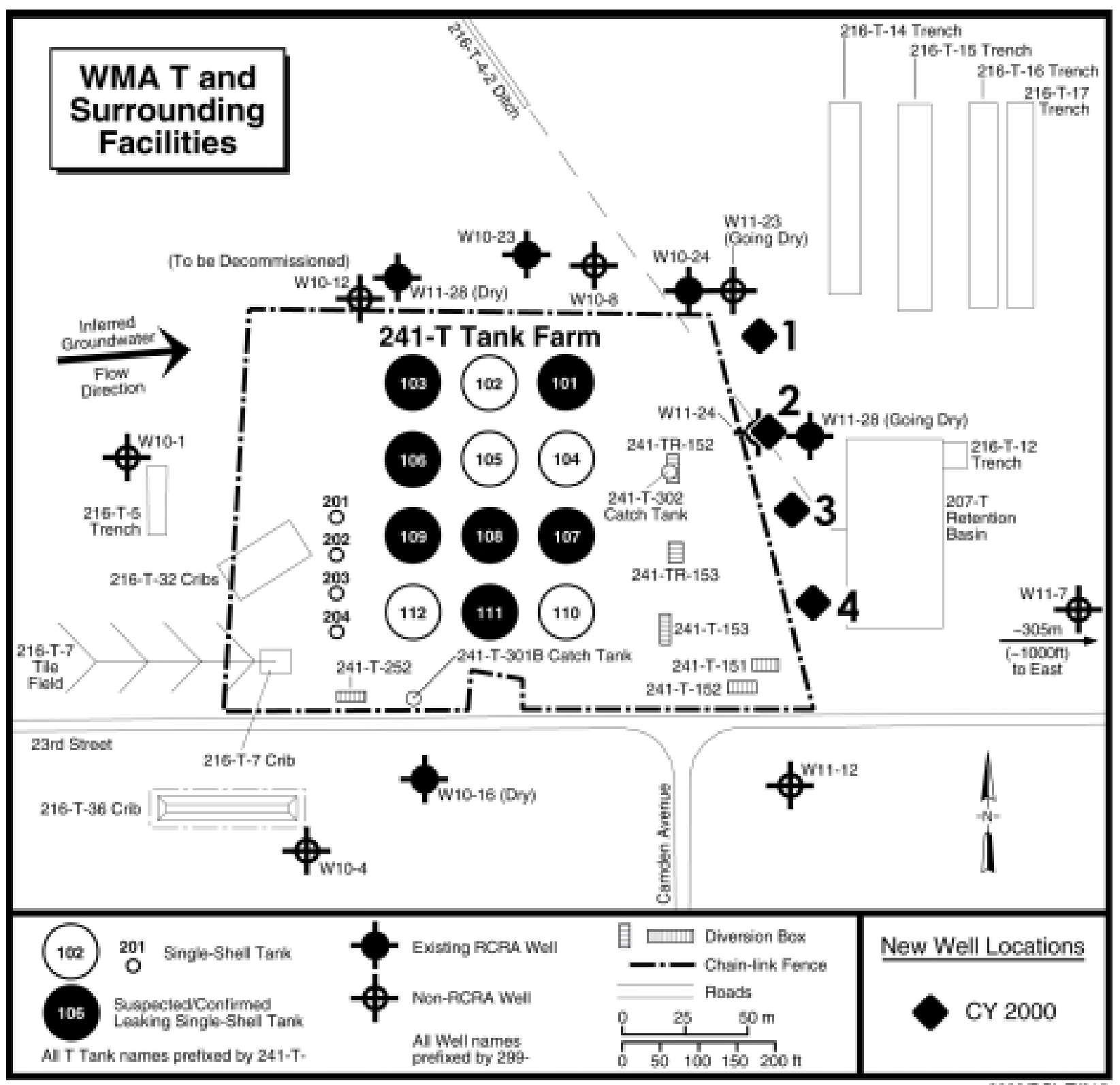

2000 DCUT/015

Figure 3.1. Locations of Wells in Assessment Network

declined rapidly with increasing depth. These observations suggest different sources that originated under different hydraulic conditions resulting in variable depth distribution of the contaminants.

Several older non-RCRA wells (see Table 3.1a) also are included in the assessment network. For example, a non-RCRA well (299-W11-24) is used to replace a RCRA well (299-W11-28) that is going dry. Well 299-W11-24 will be included in the assessment network until a new RCRA compliant well that replaces well 299-W11-24 is completed, developed, and ready for sampling. These wells, drilled prior to 1990, normally have carbon steel casings that are perforated to allow access to the aquifer. Because of 
Table 3.1b. Additional Assessment Wells, Constituent List, and Sample Frequency Planned for WMA T in Calendar Year 2001 (not listed in order of priority)

\begin{tabular}{||l|c|c|c|c|l||}
\hline \multicolumn{1}{||}{ Well } & $\begin{array}{c}\text { RCRA } \\
\text { Standard }\end{array}$ & $\begin{array}{c}\text { Sampling } \\
\text { Frequency }^{(\text {a) }}\end{array}$ & $\begin{array}{c}\text { Constituent } \\
\text { List }^{(\mathrm{b})}\end{array}$ & Co-Sample & \multicolumn{1}{c||}{ Comment } \\
\hline \hline \multicolumn{5}{|c|}{ New Wells to be Drilled in Calendar Year 2001 } \\
\hline Well 5 & Y & Q & A,B & & $\begin{array}{l}\text { Replace non-RCRA upgradient well } \\
\text { 299-W10-1 }\end{array}$ \\
\hline Well 6 & Y & Q & A,B & & $\begin{array}{l}\text { Monitor at depth to evaluate down- } \\
\text { gradient contaminant depth distribution }\end{array}$ \\
\hline Well 7 & Y & Q & A,B & $\begin{array}{l}\text { A mid-field well to evaluate horizontal } \\
\text { and vertical extent of downgradient } \\
\text { contamination }\end{array}$ \\
\hline Wells 8 and 9 & Y & Q & A,B,C & $\begin{array}{l}\text { Two wells adjacent to calendar year } \\
\text { 2000 Well 1; these wells will evaluate } \\
\text { contamination and monitor at selected } \\
\text { depths }\end{array}$ \\
\hline $\begin{array}{l}\text { (a) Q = Quarterly. } \\
\text { (b) Letters refer to lists in Table 3.2. } \\
\text { (c) Pending funding availability. }\end{array}$ & & \\
\hline
\end{tabular}

the materials used to construct these wells and the potential effects of corrosion on groundwater chemistry, special care must be taken to maintain these wells and to purge the wells before sampling. However, with proper precautions, they should yield water samples adequately representative of the aquifer.

The need for additional new RCRA wells beyond those discussed above will be evaluated at least on an annual basis to determine the effects of declining water tables, changing flow directions, and contaminant distribution patterns.

\subsection{Constituents and Sampling Frequency}

Sampling frequency (see Tables 3.1a and b) will depend on both proximity to the WMA and trends in contaminant concentrations in the well. Initially, wells immediately adjacent to the WMA will be sampled on a quarterly basis and more distant well (299-W11-7) on a semiannual basis. If there is a rapid increase in technetium-99 activity, or if technetium-99 exceeds the drinking water standard, sampling frequency in that well will be increased to quarterly. As the assessment study proceeds, the sampling frequencies may be increased or decreased on the basis of flow rates, flow directions, or contaminant patterns.

The analytical constituent lists (Table 3.2) are designed to meet monitoring needs of the assessment program. List A is the basic list for monitoring in near-field wells. Inductively coupled plasma (ICP) metals and anions, coupled with radionuclide analysis provide information on the major contaminants associated with the WMA and for calculating the ratios necessary for plume fingerprinting. 


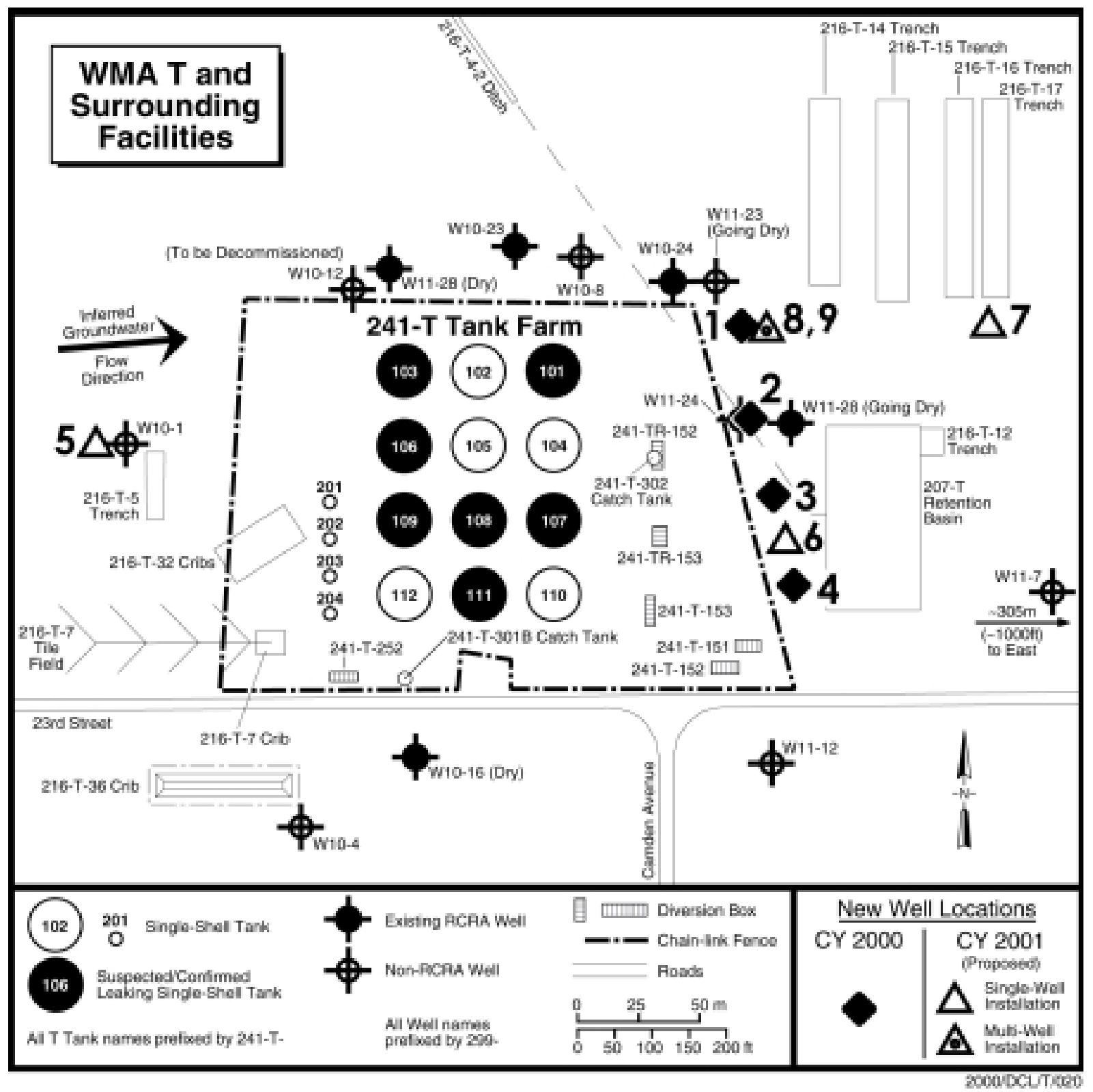

Figure 3.2. Proposed New Well Locations for WMA T

Total organic carbon (List B), a RCRA indicator parameter, will be analyzed in selected near-field downgradient well samples because many of the tanks contain organics (complexants) and because it is a co-contaminant in well 299-W11-27. Total organic halogen is not on the list because halogenated hydrocarbons are not believed to be significant tank waste components. Carbon tetrachloride and trichloroethene are present in groundwater throughout the area; however, they are principally a result of waste disposal activities at the Plutonium Finishing Plant and are tracked by monitoring activities required by the Atomic Energy Act. Because of its importance in delineating contaminant sources in the vicinity of the WMA, carbon tetrachloride may be added to the constituent list when needed. 
Table 3.2. Analytical Constituents for WMA T

\begin{tabular}{||l|l|l||}
\hline \multicolumn{1}{|c|}{ List A } & \multicolumn{1}{c|}{ List B } & \multicolumn{1}{c||}{ List C } \\
\hline \hline Temperature & Total organic carbon ${ }^{(\mathrm{a})}$ & Strontium-90 $^{(\mathrm{b})}$ \\
\hline Specific Conductance & & Gamma scan \\
\hline $\mathrm{pH}$ & & Special Analyses $^{(\mathrm{c})}$ \\
\hline ICP Metals & & \\
\hline Anions & & \\
\hline Alkalinity & & \\
\hline TDS & & \\
\hline Gross Alpha & & \\
\hline Gross Beta & & \\
\hline Technetium-99 & & \\
\hline Tritium & \\
\hline $\begin{array}{l}\text { (a) Individual analysis. } \\
\text { (b) Non-routine analysis. If analytical result of strontium is shown as nondetects, it }\end{array}$ \\
(c) Non-routine analyses and include ruthenium-101, selenium-79, americium-241, \\
(CCP = Inductively coupled plasma. \\
TDS = Total dissolved solids.
\end{tabular}

Ruthenium-101 (stable), selenium-79 ( $\mathrm{t}_{1 / 2}=6.5 \times 10^{4}$ years), neptunium-237 ( $\mathrm{t}_{1 / 2}=2.14 \times 10^{6}$ years), and americium-241( $\mathrm{t}_{1 / 2}=244$ years), (List C) are tank waste constituents that are known to be present in tank waste and may be detectable in groundwater in low concentrations. Because of low expected concentrations, these constituents may be analyzed only in selected samples that have high concentrations of technetium-99, another mobile tank waste constituent. If results are positive for the high technetium-99 samples, the analysis may be extended to other samples.

\subsection{Hydraulic Testing}

Hydrologic data for the WMA T area are incomplete. Slug tests during completion of two RCRA wells yielded estimates of hydraulic conductivity. In addition, a tracer test carried out on the north side of WMA T in 1979, as part of the T-106 tank leak study (Routson et al. 1979), yielded a lower limit for

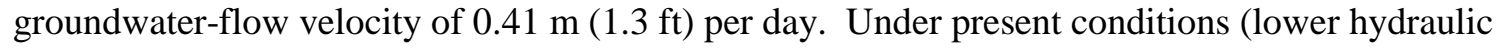
gradient), that determination indicates a groundwater flow velocity lower limit of approximately $0.2 \mathrm{~m}$ $(0.7 \mathrm{ft})$ per day. The tests described below are designed to provide hydrologic data that will allow evaluation of groundwater-flow rates and contaminant migration rates in the vicinity of WMA T and may be used in risk analysis. 
Hydrologic testing is planned for the two monitoring wells (299-W10-24 and 299-W10-23) drilled during 1998 and selected new wells planned for calendar year 2000. The hydrologic test plan includes several individual test elements designed for specific characterization information. Identified individual test and parameters to be measured include

- Slug Testing - evaluating well-development conditions and providing preliminary hydraulic property information (e.g., hydraulic conductivity) for design of subsequent hydrologic tests

- Tracer-Dilution Test - determining the vertical distribution of hydraulic conductivity and/or groundwater flow velocity within the well screen section

- Tracer-Pumpback Test - tracer removal and characterizing effective porosity, an important hydraulic transport parameter

- Pumping Test/Recovery - conducted in concert with tracer-pumpback phase. Analysis of drawdown and recovery data provides quantitative hydraulic characterization property information (e.g., hydraulic conductivity, storativity, specific yield).

As noted above, slug testing is designed primarily to provide initial estimates of hydraulic properties to design more quantitative hydrologic tests. Several slug tests will be conducted at different stress levels during this characterization phase to provide information pertaining to well development and possible presence of near-well heterogeneities. After slug testing, a tracer-dilution test will be conducted on selected wells, and, in turn, a combined constant-rate pumping and tracer-pumpback test. Information obtained from the detailed hydraulic characterization will provide aquifer information pertaining to flow velocity, hydraulic properties, and effective porosity in the vicinity of the well site, as well as well performance/efficiency. This information will serve as input to numerical models used to simulate groundwater flow and to predict contaminant transport within the Hanford Site.

For the tracer-dilution test, a solution of potassium or lithium bromide (or other suitable tracer) of known concentration will be circulated/mixed within the well screen section. The decline (i.e., dilution) of tracer with time within the well screen will be monitored directly using bromide specific-ion electrodes located at known depth intervals. Based on the dilution characteristics observed, the vertical distribution (i.e., heterogeneity) of hydraulic properties and/or flow velocity can be estimated for the formation/well screen section.

After the tracer-dilution test is completed, and the tracer has sufficient time to clear the borehole, a pump will be placed in the well and water will be discharged at a constant rate to recover most of the tracer. The tracer-pumpback phase will be complete when the centroid of tracer concentration has been recovered. Analysis of the tracer recovery pattern will provide information on hydraulic conductivity and effective porosity. In order to quantitatively characterize the hydraulic properties of the surrounding formation, the constant-rate-pumping test might be extended for duration longer than required for "capturing" the centroid of tracer concentration. The time required to obtain representative hydrologic property results will be determined using diagnostic derivative analysis results of the drawdown data 
obtained from the pumped and nearby observation well locations. A detailed description of the use of derivative analysis techniques is provided in Spane (1993) and Spane and Wurstner (1993).

After the constant-rate pumping test is complete, the recovery of water levels within the pumped and nearby observation wells will be monitored. The time required for recovery monitoring will be assessed through the use of diagnostic derivative analysis, similar to drawdown data during the pumping phase. For general planning purposes, however, recovery monitoring should be maintained for a period equal to the pumping period and preferably longer.

One important planning assumption for the hydrologic testing is that the water produced during pumping can be disposed of as ordinary purgewater. If the water must be handled as " $F$ " listed waste, the cost may prohibit hydrologic testing that requires pumping large volumes of water.

As of September 30, 2000, all of the above identified hydrologic tests were completed for well 299-W10-24 and slug test was completed for well 299-W10-23. Preliminary results obtained from detailed hydrologic characterization tests within the WMA are presented in Appendix D. Final results will be documented in PNNL technical reports and in the groundwater annual report.

\subsection{Groundwater Flow Direction}

Determining both the direction and velocity of groundwater flow is important to assess and predict contaminant transport. The tests discussed in Section 3.4 provide estimates of groundwater flow velocities; however, they do not allow estimates of groundwater flow direction.

A number of techniques, including downhole flow measurements, and accurate determination of water-table elevations can be used to determine the direction of groundwater flow. It should be noted, however, that each of the identified techniques has strengths and weaknesses. For example, there is a high degree of uncertainty about the accuracy and reliability of downhole flow measurements, and the fact that they represent only a point in space.

For initial evaluation of groundwater flow directions at WMA T, trend-surface analysis will be applied to refined water-table elevation measurements. As of September 30, 2000, trend-surface analysis was completed for well 299-W10-24 (see Appendix D, Table 5). If, at a later date, the uncertainties about downhole flow meter measurements are positively resolved, flow meter measurements may be used to supplement or corroborate trend-surface analysis results.

\subsection{Plume Extent}

Regulations concerning RCRA assessment require both the horizontal and vertical extent of contaminant plumes be determined. Because the contaminant plume extends in both upgradient and downgradient directions from monitoring wells, it is important to determine the source as well as the downgradient extent of the plume. Groundwater monitoring wells, either existing or newly installed, are necessary to provide sampling data to establish the concentration of contaminants released from the WMA and the rate and extent of their migration. Four new wells are planned for calendar year 2000 to enhance the 
downgradient coverage (see Figure 3.1). As of October 2000, three of the planned calendar year 2000 wells were drilled. Additionally, five wells are planned for calendar year 2001 to enhance the delineation of horizontal as well as vertical contaminant distribution (see Figure 3.2). If contamination is detected at depth in downgradient wells, the results from monitoring wells installed at these locations will be evaluated to determine whether deep upgradient wells will be needed to differentiate possible upgradient sources of the deep contamination. The determination of sources within the WMA can be done only through the integration of groundwater sampling data with vadose characterization results within the WMA. Information on the depth distribution of contamination within the aquifer can be obtained through drilling new wells into the deeper portions of the aquifer or by discrete level sampling of older wells with long perforated intervals within the aquifer. In this study, both approaches will be used. In all of these determinations, it is important to use the overall pattern ("fingerprint") of contaminant concentrations, not simply the presence or absence of a particular contaminant to determine the impact of the contaminant plume in a particular well.

\subsubsection{Plume Fingerprinting}

Given the complexity of groundwater contamination patterns and the multiple potential sources for most contaminants observed in groundwater, individual contaminants are not reliable indicators of source. However, Johnson (1997), Johnson and Chou (1998), and Hodges (1998) have shown that ratios of chemical constituents and isotopes, coupled with process knowledge, may allow distinction of different groundwater contaminant source chemistries (see Section 2.2). In this context, "fingerprint" is defined as a set of chemical and isotopic parameters that are considered unique to a particular contaminant source. Given different reactor fuel burnup parameters, different processes used to extract plutonium from the fuel, and the treatment and mixing of the waste after reaching the tank farms, it is highly unlikely that any two contaminant sources would share exactly the same fingerprint (see Agnew 1997). Ratios to be used include sodium/calcium, tritium/technetium-99, and nitrate/technetium-99. Contour plots of the ratios should allow discrimination of tank waste effects from contamination originating from either tank or crib sources and will facilitate determination of the extent of the contaminant plume.

In addition to nitrate/technetium-99 ratios, some trace mobile tank waste constituents (ruthenium-101, selenium-79, and neptunium-237 and possibly complexed americium-241) should be present in very low concentrations in groundwater contaminated by tank waste. The ratios of these isotopes to each other and to other mobile tank waste constituents could be specific to different waste sources within the tank farms. Thus, if concentrations for one or more of these isotopes can be determined for groundwater, and compared with ratios determined for the soluble fraction from solid samples within tank farm vadose contaminant plumes, it may be possible to identify specific source areas within the WMA. Because these tank waste constituents will most likely be present in detectable concentrations in groundwater containing high concentrations of mobile constituents such as technetium-99, initial analysis for them will be restricted to selected high technetium-99 samples from wells $299-\mathrm{W} 10-24$ and new well ${ }^{\#} 1$ which is south of well 299-W11-23 (see Table 3.1a). 


\subsubsection{Horizontal Extent}

The contaminants that resulted in continued assessment at WMA T were originally detected only in well 299-W11-27, located at the northeast comer of the tank farm (see Figure 3.1). A subsequent increase in technetium-99 in well 299-W11-23 (see Figure 2.4), starting in November 1997, may indicate this well intercepts the contaminant plume. The initial plume fingerprint is consistent with that determined for well 299-W11-27 (Hodges 1998).

The geometry of the plume is uncertain. Well 299-W11-23 is located approximately $20 \mathrm{~m}(66 \mathrm{ft})$ east of well 299-W11-27, not on a direct flow path from likely sources within the WMA. In addition, a flow rate as slow as $0.1 \mathrm{~m}(0.3 \mathrm{ft})$ per day would have carried the contaminants approximately $100 \mathrm{~m}(328 \mathrm{ft})$ past well 299-W11-27 in the two and a half years since their first detection, well past well 299-W11-23. Thus, the contaminants detected in well 299-W11-23 are either the result of lateral spreading of a northeasterly trending contaminant plume or a plume that was propagating in a northeasterly direction and is now being pushed in a more easterly direction as a result of changing groundwater flow directions.

Four additional wells will be drilled in calendar year 2000 to better define the extent of groundwater contamination from this WMA and to evaluate the validity of forecasts based on hydrologic parameters. This is particularly important given the aquifer heterogeneity found within the 200 West Area and changing flow conditions resulting from declining water-table mounds.

\subsubsection{Vertical Extent}

A preliminary attempt to detect vertical variation of contaminants within the aquifer was made by sampling the top of the aquifer in well 299-W11-27, using a Kabis Sampler. Results from this sampling were consistent with a decrease in contaminants near the top of the aquifer. An upward decrease in contaminant concentrations near the water table in that well may also be indicated by the decrease in contaminants sampled by the fixed pump as the water table has declined over the past several years.

The thickness of the aquifer above the basalt is about $56 \mathrm{~m}(\sim 184 \mathrm{ft})$ beneath WMA T. Thus, determination of the vertical distribution of contaminants is an important task, complicated by threedimensional variation in degree of cementation and hydraulic properties within the aquifer. The distribution of contaminants with depth, in addition to indicating the volume of contaminated groundwater, may provide important constraints on the transport mechanisms that resulted in the observed contamination. The depth of penetration of contaminants into the aquifer depends on both the densities of waste liquids reaching the water table and rate at which they arrive (relative to groundwater-flow rate). Denser liquids would be representative of relatively unmodified tank waste, while tank waste mobilized by surface water would tend to be more dilute and, therefore, of lower density. Denser liquids and rapid arrivals tend to penetrate deeper into the aquifer, while low arrival rates may result in thin layers of contaminants at the top of the aquifer.

New monitoring well 299-W10-24 (299-W11-27 replacement) was drilled through the entire thickness of the unconfined aquifer. Results from this effort indicated deeply distributed contaminants. High nitrate was detected throughout the entire unconfined aquifer, whereas technetium- 99 was the highest at 
the top and declined more rapidly with depth. Tritium and carbon tetrachloride both exhibited a subsurface maximum at a depth of 20 to $30 \mathrm{~m}$ (66 to $98 \mathrm{ft}$ ) below the water table. This observation suggests a tank waste "signature" occurs in the shallower portion of the aquifer while the deeply distributed (high nitrate) plume is of a different origin, possibly waste from the Plutonium Finishing Plant crib. This type of information is useful to support decisions regarding corrective or remedial action.

Vertical sampling within screened intervals to examine the depth variation in the upper aquifer will be carried out after a sufficient equilibration time has passed (2 to 3 months) to allow for recovery from any hydraulic disturbance due to sampling or other testing. The vertical sampling, to be conducted using either a KABIS ${ }^{1}$ sampler or other suitable multi-level device, will include the collection of samples as near the top of the aquifer as possible as well as at selected depths.

\footnotetext{
${ }^{1}$ KABIS is a registered trademark of SIBAK Industries Limited, Peoria, Illinois.
} 


\subsection{References}

40 CFR 265, Code of Federal Regulations, Title 40, Part 265. Interim Status Standards for Owners and Operators of Hazardous Waste Treatment, Storage, and Disposal Facilities.

Atomic Energy Act, as amended, Ch. 1073, 68 Stat. 919,42 USA 2011 et seq.

Agnew, S. F. 1997. Hanford Tank Chemical and Radionuclide Inventories: HOW Model Rev. 4. LA-UR-96-3860, Los Alamos National Laboratory, Los Alamos, New Mexico.

Caggiano, J. A., and C. J. Chou. 1993. Interim-Status Groundwater Quality Assessment Plan for the Single Shell Tank Waste Management Areas T and TX-TY. WHC-SD-EN-AP-132, Westinghouse Hanford Company, Richland, Washington.

Caggiano, J. A., and S. M. Goodwin. 1991. Interim-Status Groundwater Monitoring Plan for the SingleShell Tanks. WHC-SD-EN-AP-012, Rev. 1, Westinghouse Hanford Company, Richland, Washington.

DOE. 2000. Fiscal Year 1999 Annual Summary Report for the 200-UP-1, 200-ZP-1, and 100-NR-2 Pump-and-Treat Operations and Operable Units. DOE/RL-99-79, Rev. 0, U.S. Department of Energy, Richland Operations Office, Richland, Washington.

DOE/RL-99-36, Rev. 0. 1999. Phase 1 RCRA Facility Investigation/Corrective Measures Study Work Plan for Single-Shell Tank Waste Management Areas. U.S. Department of Energy, Richland Operations Office, Richland, Washington.

Ecology - Washington State Department of Ecology, U.S. Environmental Protection Agency, and U.S. Department of Energy. 1998. Hanford Federal Facility Agreement and Consent Order. Document No. 89-10, Rev. 5 (The Tri-Party Agreement), Olympia, Washington.

Freeman-Pollard, J. R., J. A. Caggiano, S. J. Trent, and EBASCO/Hart Crowser. 1994. Engineering Evaluation of the GAO/RCED-89-157, Tank 241-T-106 Vadose Zone Investigation. BHI-0061, Bechtel Hanford Company, Richland, Washington.

Gee, G. W., M. J. Fayer, M. L. Rockhold, and M. D. Campbell. 1992. "Variations in Recharge at the Hanford Site." Northwest Sci. 66:237-250.

Hartman, M. J., L. F. Morasch, and W. D Webber (eds.). 2000. Hanford Groundwater Monitoring for Fiscal Year 1999. PNNL-13116, Pacific Northwest National Laboratory, Richland, Washington.

Hodges, F. N. 1998. Results of Phase I Groundwater Quality Assessment for Single-Shell Tank Waste Management Areas T and TX-TY at the Hanford Site. PNNL-11809, Pacific Northwest National Laboratory, Richland, Washington. 
Jensen, E. J., S. P. Airhart, M. A. Chamness, T. J Gilmore, D. R. Newcomer, and K. R. Oster. 1989. 40 CFR 265 Interim-Status Ground-Water Monitoring Plan for the Single-Shell Tanks. WHC-SD-ENAP-012, Rev. 0, Westinghouse Hanford Company, Richland, Washington.

Johnson, V. G. 1997. Vadose Zone Contamination, Chapter 4.0 in Hanford Site Groundwater Monitoring for Fiscal Year 1996, M. J. Hartman and P. E. Dresel, (eds.). PNNL-11470, Pacific Northwest National Laboratory, Richland, Washington.

Johnson, V. G., and C. J. Chou. 1998. Results of Phase I Groundwater Quality Assessment for SingleShell Tank Waste Management Areas S-SX the Hanford Site. PNNL-11810, Pacific Northwest National Laboratory, Richland, Washington.

Lindsey, K. A. 1995. Miocene and Pliocene-Aged Suprabasalt Sediments of the Hanford Site, SouthCentral Washington. BHI-00184, Bechtel Hanford Company, Richland, Washington.

Resource Conversation and Recovery Act, as amended, Public Law 94-580, 90 Stat. 2795, 42 USC 6901 et seq.

Routson, R. C., W. H. Price, D. J. Brown, and K. R. Fecht. 1979. High-Level Waste Leakage from the 241-T-106 Tank at Hanford. RHO-ST-14, Rockwell Hanford Operations, Richland, Washington.

Routson, R. C. 1981. Volume of Sediments Contaminated with ${ }^{90} \mathrm{Sr}$ and ${ }^{137} \mathrm{Cs}$ in the T-Tank Farm, letter from R. C. Routson to W. F. Heine, No. 72710-81-120, dated May 25, 1981, WIDS.

Serne, R. J., J. M. Zachara, and D. S. Burke. 1998. Chemical Information on Tank Supernatants, Cs Adsorption from Tank Liquids Onto Hanford Sediments, and Field Observations of Cs from Past Tank Leaks. PNNL-11495, Pacific Northwest National Laboratory, Richland, Washington.

Spane, F. A., Jr. 1993. Selected Hydraulic Test Analysis Techniques for Constant-Rate Discharge Tests. PNL-8539, Pacific Northwest Laboratory, Richland, Washington.

Spane, F. A., Jr., and S. K. Wurstner. 1993. "DERIV: A Program for Calculating Pressure Derivatives for Use in Hydraulic Test Analysis." Ground Water, V. 32, No. 5, pp. 814-822; PNL-SA-21569 (1992).

WAC-173-303-400, Washington Administrative Code. Interim Status Facility Standards. Olympia, Washington.

Wilson, C. R., C. M. Einberger, R. L. Jackson, and R. B. Mercer. 1992. "Design of Ground-Water Monitoring Network Using the Monitoring Efficiency Model (MEMO)," Groundwater, Vol. 30, No. 6, pages $965-970$. 


\section{Appendix A}

Sampling and Analysis Plan 


\section{Appendix A}

\section{Sampling and Analysis Plan}

This appendix consists of a field sampling plan (FSP) and a quality assurance project plan (QAPP). The FSP specifies the data collection activities and schedule and the QAPP includes procedures and project controls for the activities that implement acquisition of the information needs described in Chapter 3. Planned activities include the following tasks.

- Task-1: Well drilling, hydraulic testing, and sampling

- Task-2: Transport/spatial modeling and directional mapping

- Task-3: Quarterly sampling and analysis

- Task-4: Data evaluation and reporting

- Task-5: Project planning and direction

The tasks, schedules and estimated cost to implement this continuing groundwater quality assessment are shown in Figure A.1. The data collection tasks shown in Figure A.1 are based on the rationale and discussion provided in Chapter 3. Additional background information can be found elsewhere in the main text. The dates shown in Figure A.1 are approximate times. Actual start and end dates may shift as detailed field work plans are prepared by the various subcontractors near the time the work is initiated. The need to coordinate with the Tank Farm Vadose Zone Project may also alter the schedule to accommodate co-sampling opportunities and/or to address other information needs that may be identified during the process to develop data quality objectives for the RCRA Facility Investigation/Corrective Measures Study (RFI/CMS) for Waste Management Area (WMA) T.

\section{A.1 Field Sampling Plan}

Locations of existing wells and the approximate locations of the wells to be drilled in calendar year 2000 are shown in Figure A.2. Locations of planned wells to be drilled in calendar year 2001 are shown in Figure A.3. The vadose zone portion of Well ${ }^{\#} 2$ (see Figure A.2) will be cored for the Tank Farm Vadose Zone Project and will be drilled to $30.5 \mathrm{~m}$ (100 ft) below the water table, then back filled and completed with a $10.7 \mathrm{~m}$ (35 ft) screen. Samples will be collected using a submersible pump and packer assembly. Samples will be collected and processed in accordance with the standard groundwater sampling protocol (section A.2). Details for the well drilling and characterization are included in a description of work that was submitted to Bechtel Hanford, Inc. by Pacific Northwest National Laboratory.

All other groundwater sampling, analysis and data handling will be conducted in accordance with procedures described in the following section. 


\section{A.2 Quality Assurance Project Plan}

The Hanford Groundwater Monitoring Project Quality Assurance Project Plan, ${ }^{(a)}$ hereafter referred to as the GW-QAPP, and associated subcontractor procedures/ manuals currently in place will cover the work activities required for conducting the WMA T groundwater quality investigation. Pacific Northwest National Laboratory administers the project for the Richland Operations Office of the U.S. Department of Energy, Environmental Restoration (ER) Branch.

\section{A.2.1 Groundwater Sampling and Analysis Procedures}

Sample Collection. Groundwater sampling procedures, sample collection documentation, sample preservation and shipment, and chain-of-custody requirements are described in subcontractor operating procedures/manuals and in the GW-QAPP. Quality requirements for sampling activities, including requirements for procedures, containers, transport, storage, chain of custody, and records requirements, are specified in a statement of work to the performing subcontractor (Waste Management Technical Services, Inc.). To ensure that samples of known quality are obtained, the subcontractor is required to use contractor-controlled procedures based on standard methods for groundwater sampling whenever possible. Pacific Northwest National Laboratory will review these procedures for technical quality and consistency. In addition, periodic assessments will be performed by Pacific Northwest National Laboratory to further ensure that procedures are followed to maintain sample quality and integrity. A brief description of the sampling requirements is provided below.

Samples are generally collected after three casing volumes are withdrawn or after field parameters ( $\mathrm{pH}$, temperature, specific conductance, and turbidity) have stabilized. Field parameters are measured in a flow-through chamber. Generally, turbidities should be equal to or below 5 NTU (nephelometric turbidity units, $1 \mathrm{NTU}=1 \mathrm{mg} / \mathrm{L}$ of solids) prior to sample collection. The project scientist, depending on site-specific conditions and sampling objectives, however, could override this general requirement. For example, collection of water during drilling necessarily involves turbid, unfiltered water, which will be processed further in the laboratory. Thus, the $5 \mathrm{NTU}$ requirement will be waived for these special water samples.

For routine groundwater samples, preservatives are added to the collection bottles in the laboratory prior to their use in the field. Duplicates, trip blanks, and field equipment blanks are collected as part of the general quality control program. The sampling and analysis methods and procedures and associated quality control results are described in more detail in Hartman et al. (2000).

Analytical Procedures. Procedures for field measurements ( $\mathrm{pH}$, specific conductance, temperature, and turbidity) are specified in the manufacturer's manual for each instrument used. The laboratory approved for the groundwater monitoring program will operate under the requirements of current

(a) The project quality assurance plan (ETD-012, Rev. 0) is available from Pacific Northwest National Laboratory, Richland, Washington. 


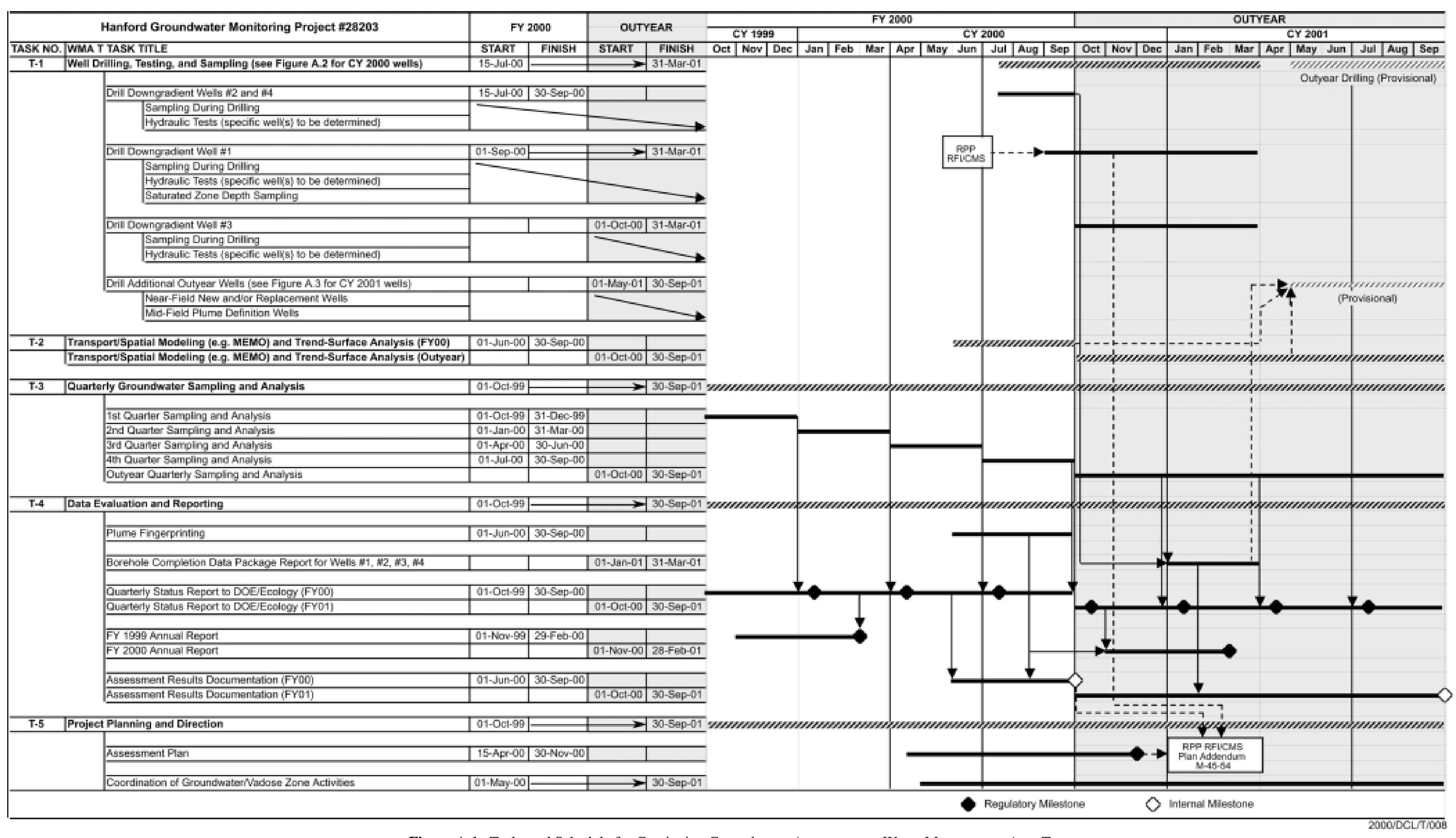

Figure A.1. Tasks and Schedule for Continuing Groundwater Assessment at Waste Management Area T 


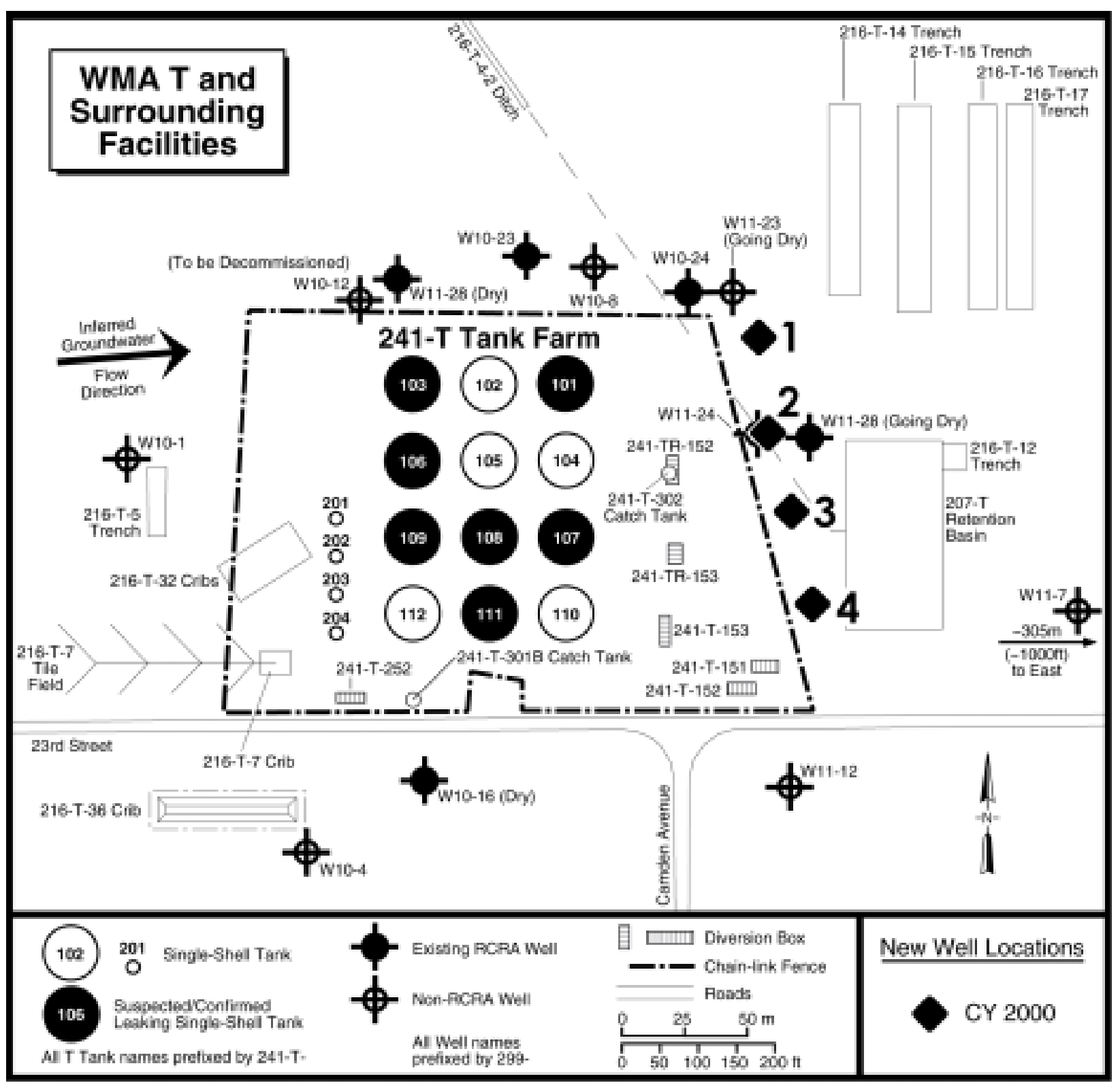

$20000 \mathrm{CLT} 015$

Figure A.2. Locations of Wells in Assessment Network for WMA T

laboratory contracts and will use standard laboratory procedures as listed in the SW-846 (EPA 1986) or an alternate equivalent. Alternative procedures, when used, will meet the guidelines of SW-846, Chapter 10. Analytical methods and quality control for the RCRA groundwater monitoring activities are described in the GW-QAPP.

Data Storage and Retrieval. All contract analytical laboratory results are submitted by the laboratory in electronic form and loaded in the Hanford Environmental Information Sys tem (HEIS) database. Parameters measured in the field either are entered into HEIS manually or through electronic transfer. 


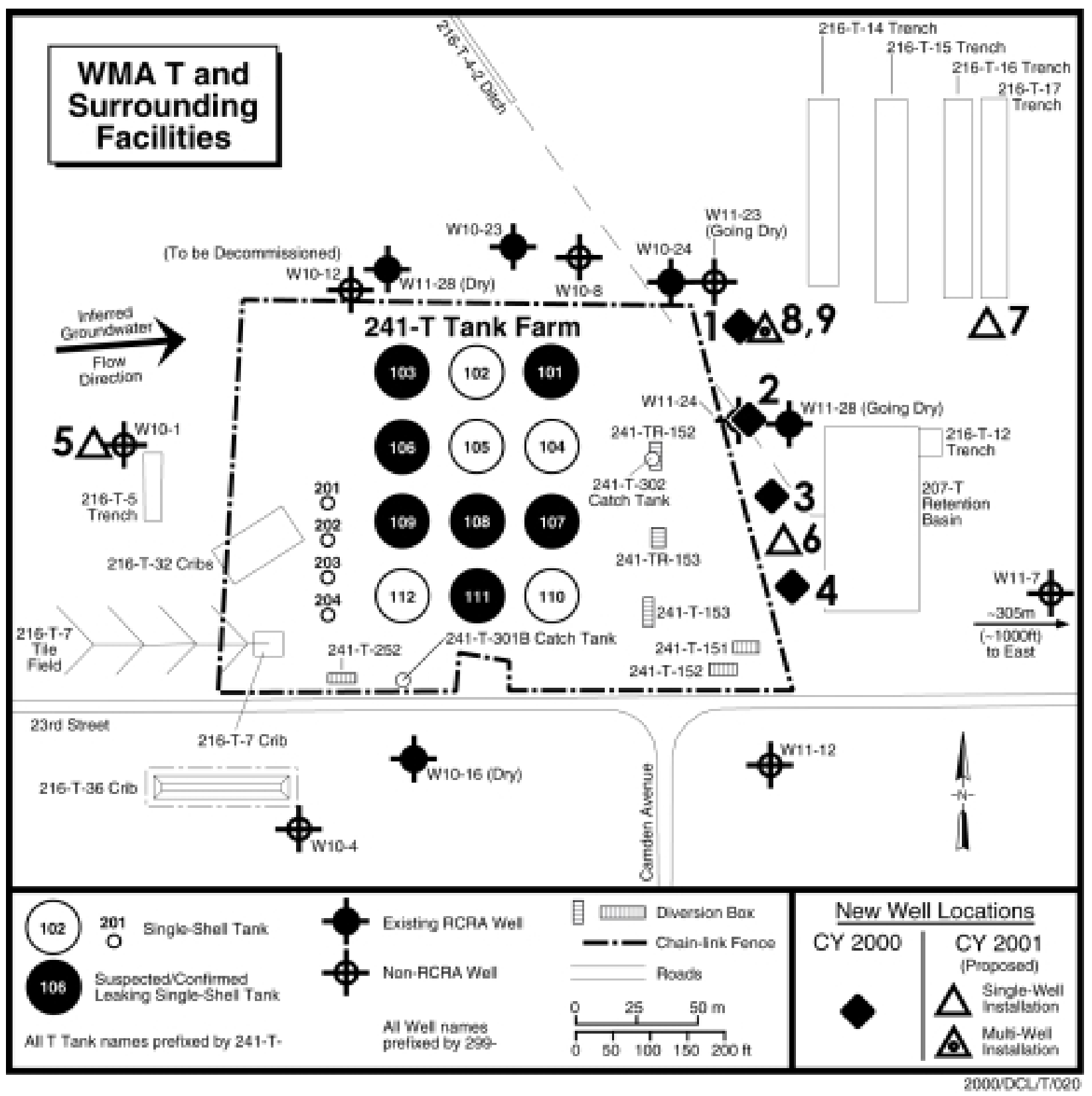

Figure A.3. Proposed New Well Locations for WMA T

Data from the HEIS database may be downloaded to smaller databases, for data validation, data reduction, and trend analysis. All field and laboratory hydrochemical results for this assessment will be entered in the publicly accessible HEIS database. Hard copy data reports and field records are considered to be the record copy of the data and are stored at Pacific Northwest National Laboratory. 


\section{A.2.2 Hydrologic Testing}

Hydraulic conductivity will be determined using slug test and tracer test procedures as specified in PNL-MA-567 (“Aquifer Testing," PNL 1999), or the most recent revision(s) or equivalent of this document. If procedures do not exist for particular tests, field instructions will be prepared prior to testing. Field data and other related information will be maintained in physical files at Pacific Northwest National Laboratory Groundwater Project Record files in Sigma V building. Hydraulic test results will be documented in a Pacific Northwest National Laboratory topical report and summarized in the assessment report for WMA T.

\section{A.2.3 Borehole Drilling and Testing}

Bechtel Hanford, Inc, manages borehole drilling and well installation under their safety and related job control procedures. Data needs and objectives from this assessment plan are used as input to Bechtel Hanford, Inc. to write the detailed specifications for the drilling contracts. The drilling and sampling activities and requirements associated with installation of a new RCRA-compliant monitoring well to assess groundwater are specified in a Description of Work (DOW) submitted to BHI by PNNL. This document specifies the drilling and sampling requirements to meet the RCRA groundwater assessment project needs for WMA T, as identified in this plan. Additional requirements for special cosampling during drilling (e.g., coring) are submitted to BHI by the requesting sponsor or project.

\section{A.2.4 References}

EPA. 1986. Test Methods for Evaluating Solid Waste Physical/Chemical Methods, $3^{\text {rd }}$ Ed. EPA SW-846, U.S. Environmental Protection Agency, Washington, D.C.

PNL. 1999. Procedures for Groundwater Investigations. PNL-MA-567. Pacific Northwest National Laboratory, Richland, Washington.

Resource Conservation and Recovery Act, as amended, Public Law 94-580, 90 Stat. 2795, 42 USC 6901, et seq.

Hartman M.J., L. F. Morasch, and W. D. Webber (eds.). 2000. Hanford Site Groundwater Monitoring for Fiscal Year 1999, PNNL-13116. Pacific Northwest National Laboratory, Richland, Washington. 


\section{Appendix B}

\section{Well Construction and Completion Summaries}


0512638

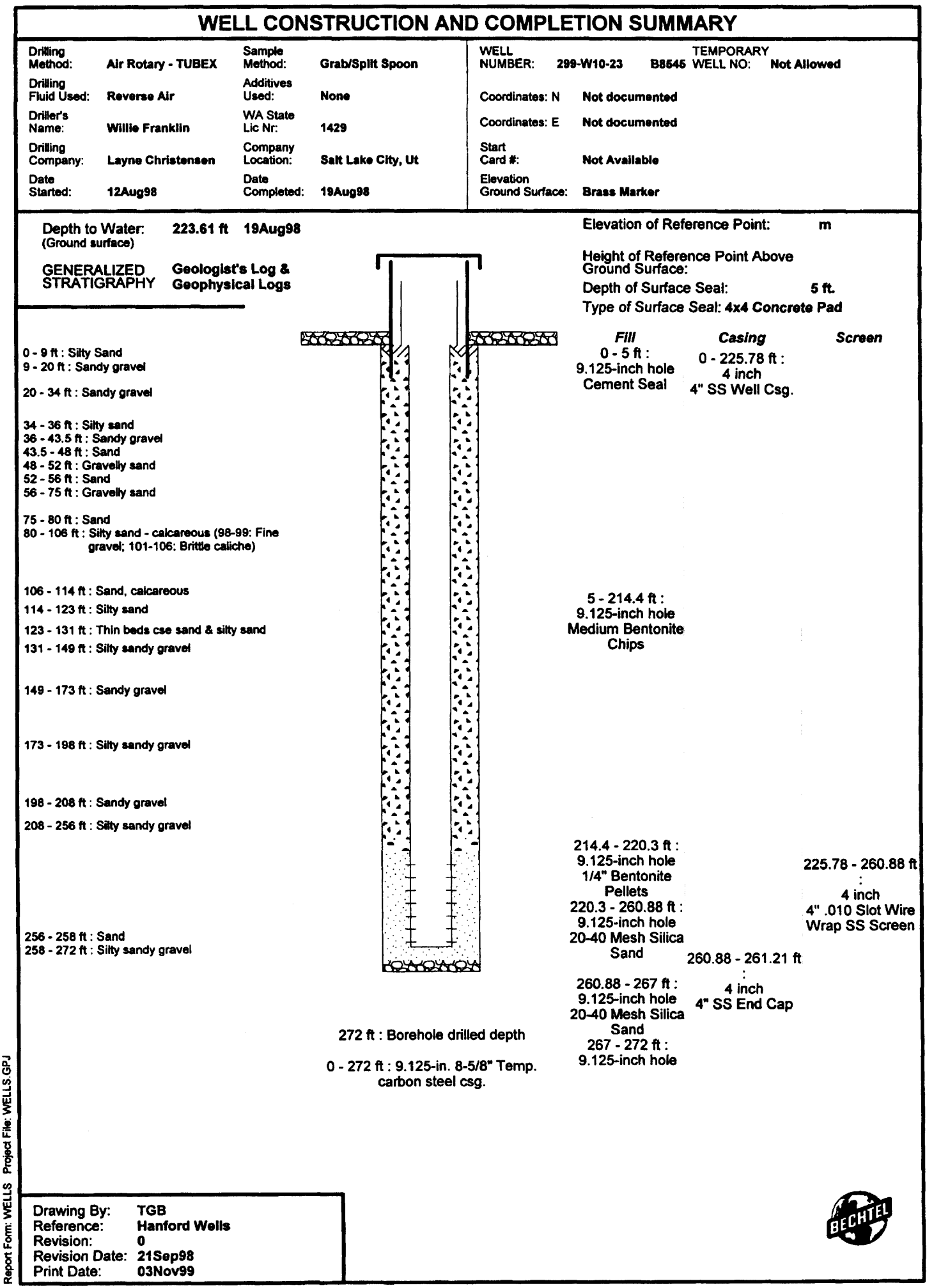




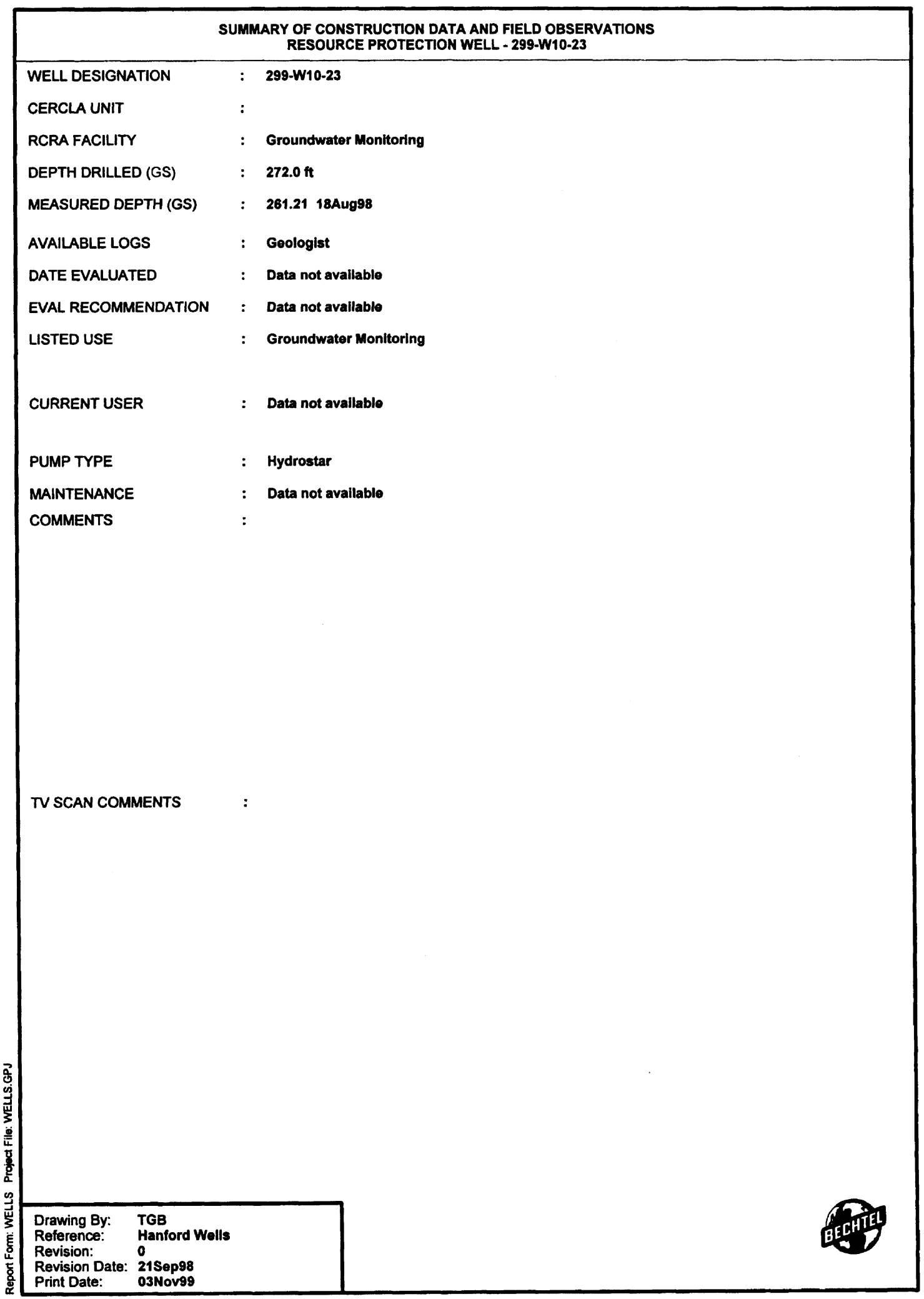

B. 2 
0502369

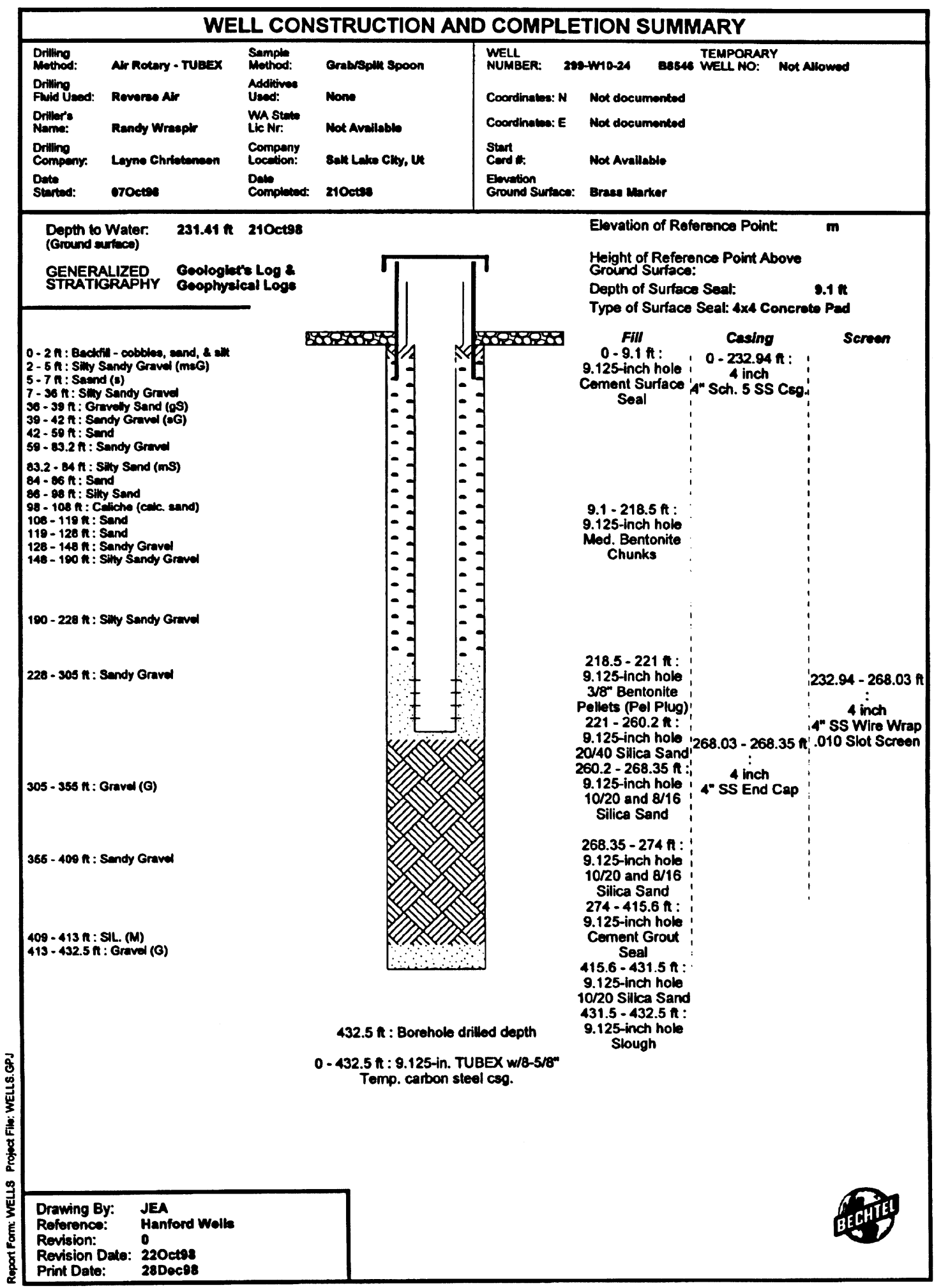




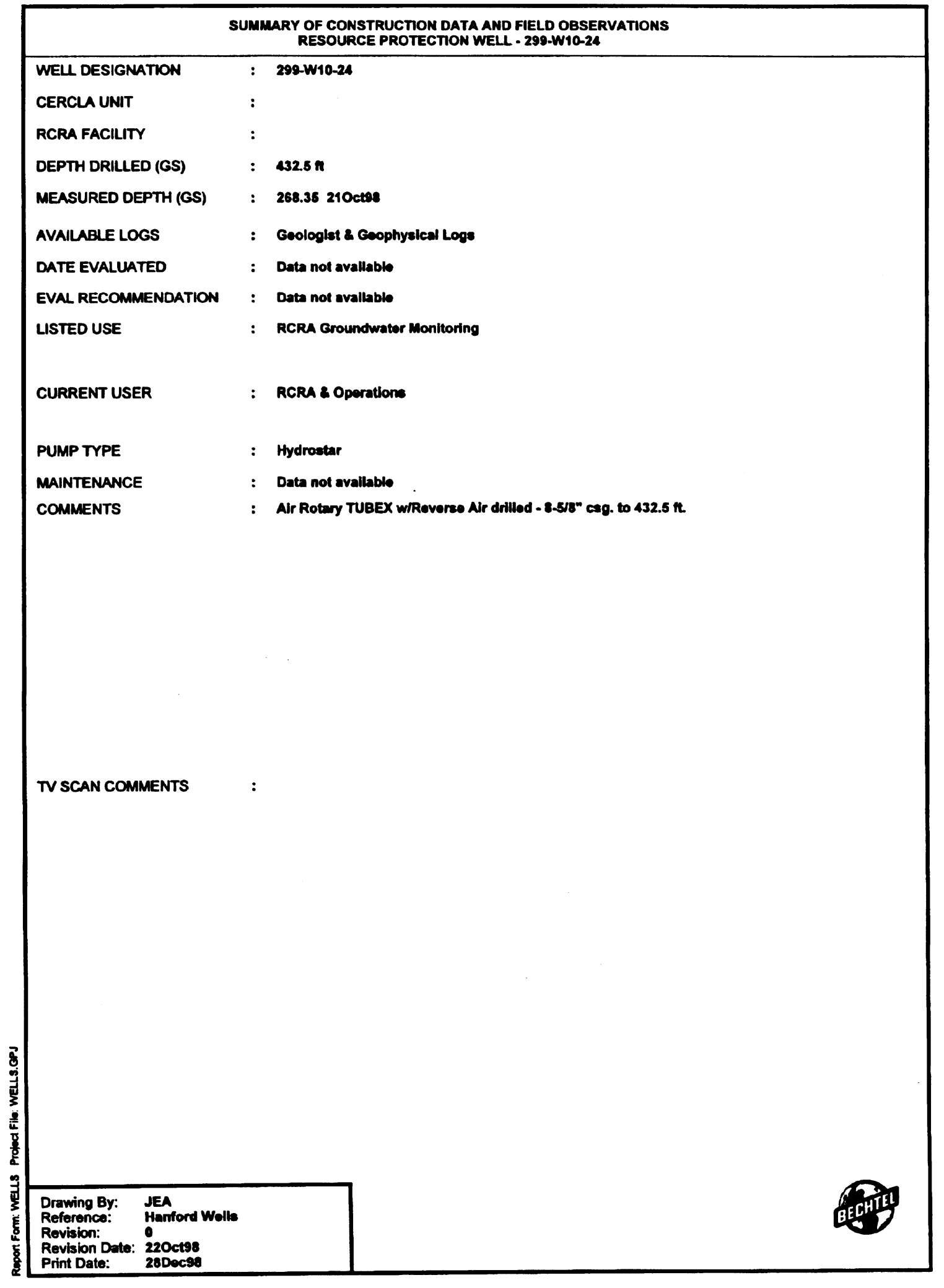




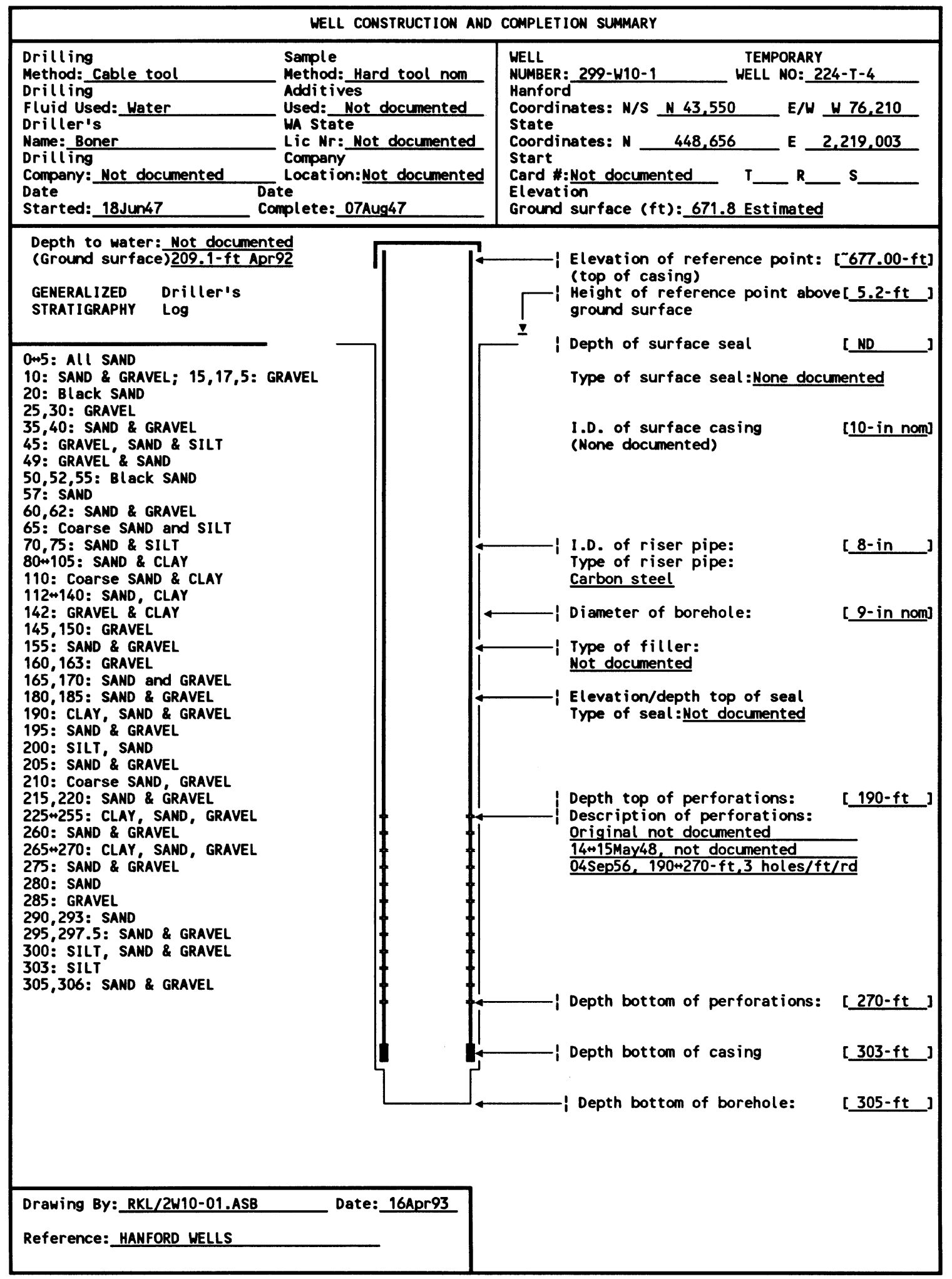




\section{SUMMARY OF CONSTRUCTION DATA AND FIELD OBSERVATIONS RESOURCE PROTECTION WELL - 299-W10-1}

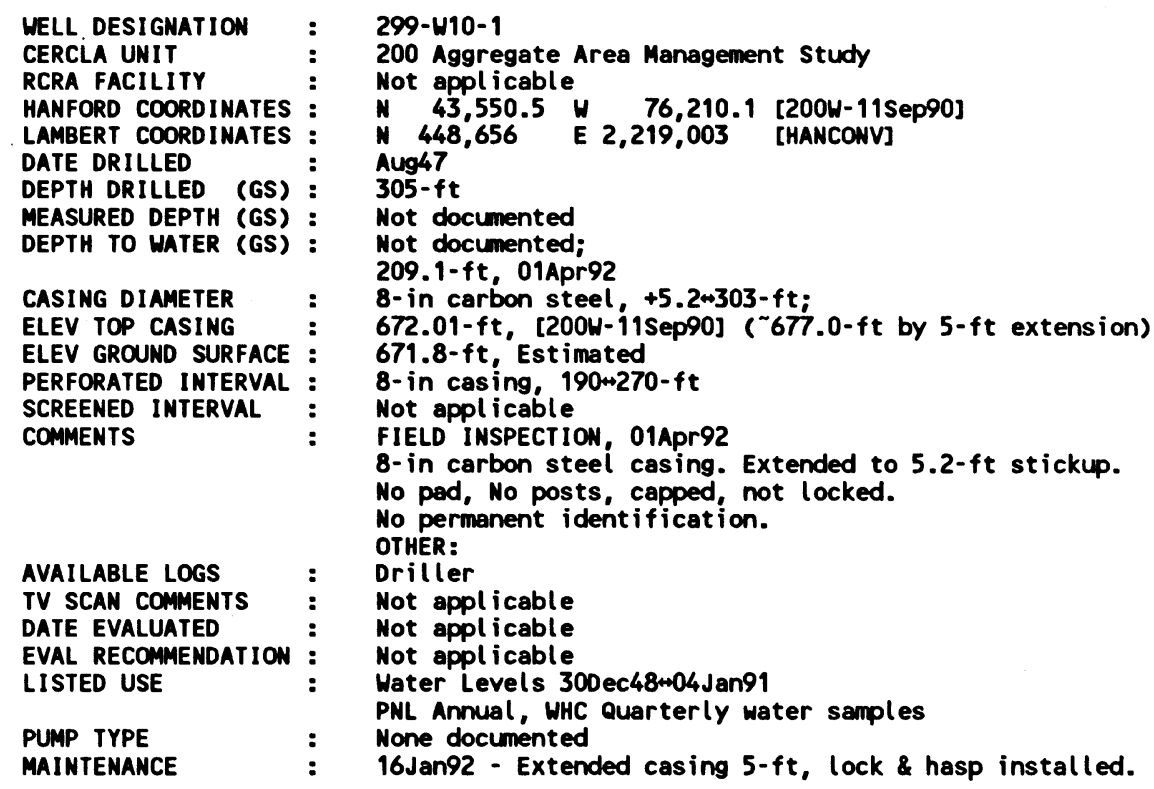




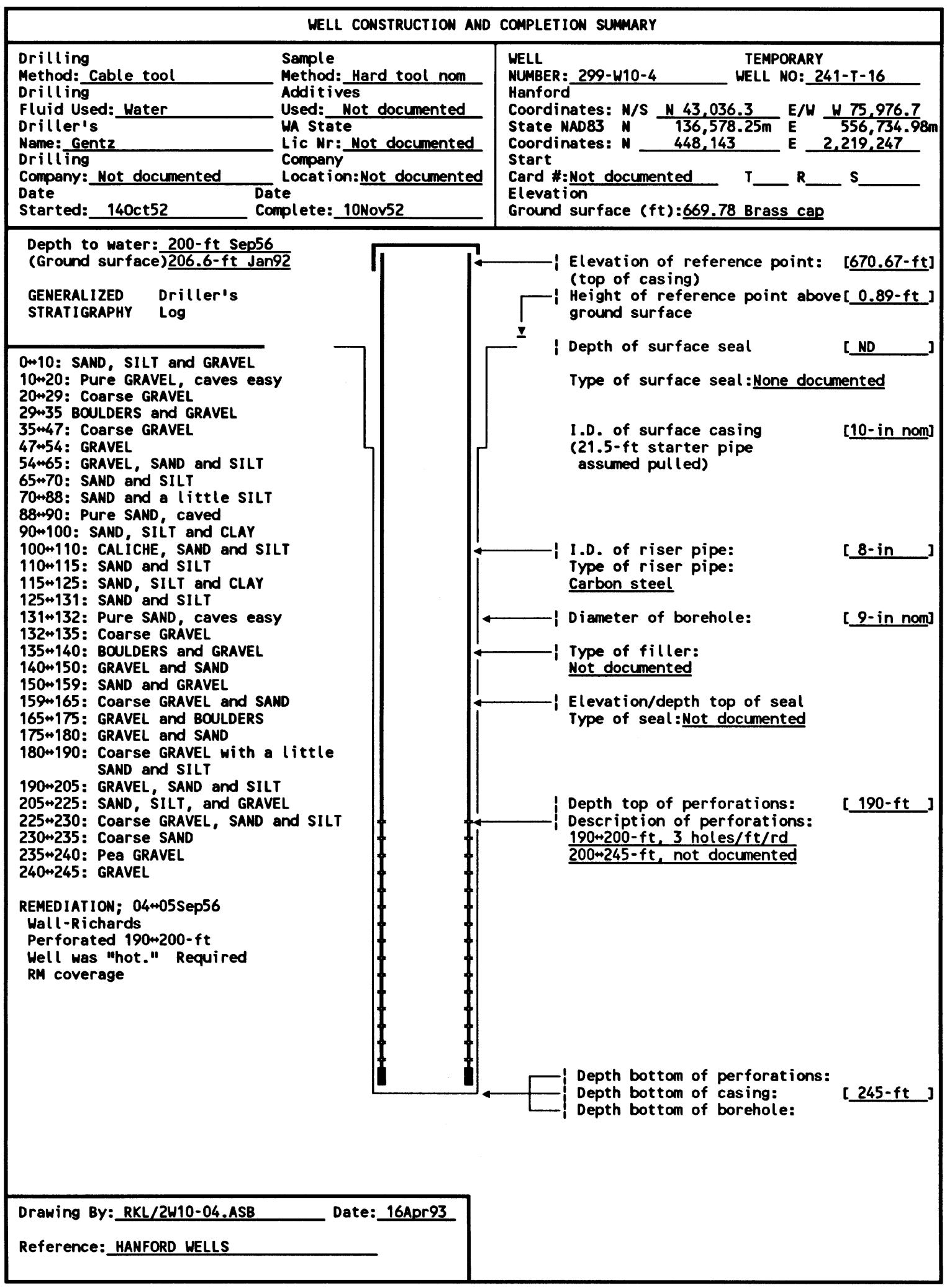


SUMMARY OF CONSTRUCTION DATA AND FIELD OBSERVATIONS

RESOURCE PROTECTION WELL - 299-W10-4

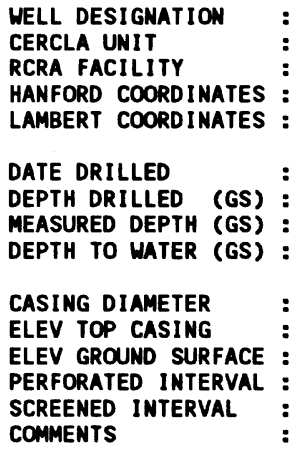

AVAI LABLE LOGS

TV SCAN COMMENTS

DATE EVALUATED

EVAL RECOMMENDATION

LISTED USE

PUMP TYPE

MAINTENANCE
299- $\mathrm{W10-4}$

200 Aggregate Area Management Study

Not appl icable

N $43,036.3$ H $75,976.7$ [200W-11Sep90]

$N 448,143 \quad E$ 2,219,247 [HANCONV]

N $136,578.25 \mathrm{~m}$ E $566,734.98 \mathrm{~m}$ [NAD83-11Sep90]

Nov52

245-ft

Not documented

200-ft, Sep56;

206.6-ft, Jan92

8 -in carbon steel, $+0.89+245-f t ;$

670.67-ft [200W-11Sep90]
[200

669.78-ft, Brass cap [200W-11Sep90]

8-in casing, $190+245-\mathrm{ft}$

Not appl icable

FIELD INSPECTION, 21 Jan92,

8-in carbon steel casing.

2-ft pad, No posts, capped and locked.

Brass cap w/identification in pad.

Not in radiation zone.

OTHER:

Driller

Not applicable

Not appl icable

Not appl icable

Water Levels 170ec52.02Jan91

PNL Annual, Semiannual, HHC Semiannual water sample schedule

Electric submersible 


\begin{tabular}{|c|c|c|c|}
\hline \multicolumn{4}{|c|}{ WELL CONSTRUCTION AND COMPLETION SUMMARY } \\
\hline $\begin{array}{l}\text { Drilling } \\
\text { Method: Cable tool } \\
\text { Drilling } \\
\text { Fluid Used: Hater } \\
\text { Driller's } \\
\text { Name: Evans/Bigham } \\
\text { Drilling } \\
\text { Company: Hatch } \\
\text { Date } \quad \text { Dat } \\
\text { Started: } 14 \text { Jun73 }\end{array}$ & \multicolumn{2}{|c|}{$\begin{array}{l}\text { Sample } \\
\text { Method: Hard tool (nom) } \\
\text { Additives } \\
\text { Used: Not documented } \\
\text { WA State } \\
\text { Lic Nr: Bigham-0036 } \\
\text { Company } \\
\text { Location: Pasco, WA } \\
\text { te } \\
\text { mplete: } 27 \text { Jun73 }\end{array}$} & 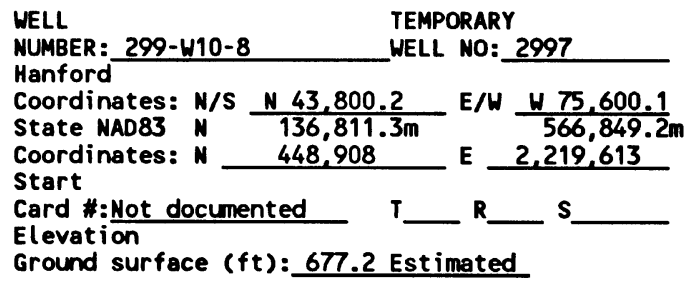 \\
\hline 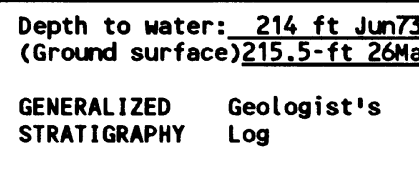 & $\frac{3}{\operatorname{ar} 93}$ & & $\begin{array}{l}\text { I Elevation of reference point: }[680.05-\mathrm{ft}] \\
\text { (top of casing) } \\
\text { Height of reference point above }[2.83-\mathrm{ft}] \\
\text { ground surface }\end{array}$ \\
\hline 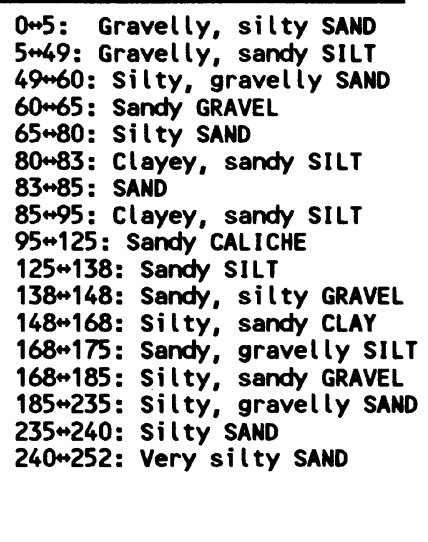 & & & $\begin{array}{l}\text { Type of surface seal : None documented } \\
\text { I.D. of surface casing } \\
\text { (If present) } \\
\text { [ I.D. of riser pipe: } \\
\text { Type of riser pipe: } \\
\text { Carbon steel } \\
\text { I Diameter of borehole: } \\
\text { Iype of filler: } \\
\text { Not documented }\end{array}$ \\
\hline & 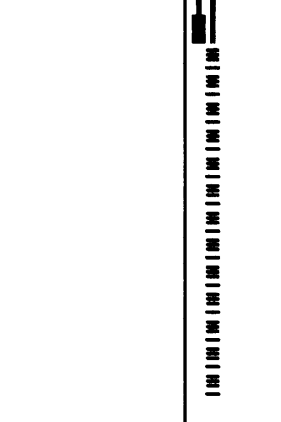 & 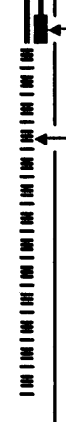 & $\begin{array}{l}\text { I Depth bottom of casing: } \\
\text { Casing pulled back from } \\
\text { total depth } \\
\text { iscreen } 40-\mathrm{ft} \text { of } \# 10 \text { slot } \\
\text { from } 205+251-\mathrm{ft} \text {, screened } \\
\text { interval assumed } 211+251-\mathrm{ft}\end{array}$ \\
\hline $\begin{array}{l}\text { Drawing By: RKL/2W10-08.ASB } \\
\text { Reference: HANFORD WELLS }\end{array}$ & _ Date: 16Apr93 & & \\
\hline
\end{tabular}




\section{SUMMARY OF CONSTRUCTION DATA AND FIELD OBSERVATIONS RESOURCE PROTECTION WELL - 299-W10-8}

WELL DESIGNATION
CERCLA UNIT
RCRA FACILITY
HANFORD COORDINATES :
LAMBERT COORDINATES :
DATE DRILLED
DEPIH DRILLED (GS)
MEASURED DEPTH (GS)
DEPTH TO WATER (GS)
CASING DIAMETER
ELEV TOP CASING
ELEV GROUND SURFACE
PERFORATED INTERVAL
SCREENED INTERVAL
COMMENTS

PUMP TYPE
MAINTENANCE
AVAILABLE LOGS
TV SCAN COMMENTS
DATE EVALUATED
LVAL RECOMMENDATION
LISTED USE
PUM

299- $-410-8$

200 Aggregate Area Management Study

single Shell Tanks

N $43,800.2$ W $75,600.1$ [200W-11Sep90]

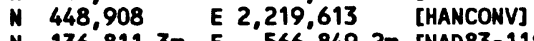

N $136,811.3 m$ E $566,849.2 m$ [NAD83-11Sep90]

Jun73

252.0-ft

Not documented

214-ft, Jun73

215.5-ft, 26Mar93

6-in carbon steel, $+2.83+210-\mathrm{ft}$,

(Pulled back from total depth)

680.05-ft, [200w-11Sep90]

677.2-ft, Estimated

Not applicable

211+251-ft telescoping

FIELD INSPECTION, 09F Eb90,

6-in carbon steel casing.

No pad, no posts, capped not locked.

No permanent identification.

In radiation zone.

OTHER:

Driller

Not applicable

Not applicable

Not appl icable

SST Monthly water level measurement, 15Jul74+26Mar93;

PNL Annual, Semiannual, WHC Semiannual water sample schedule

Electric submersible 


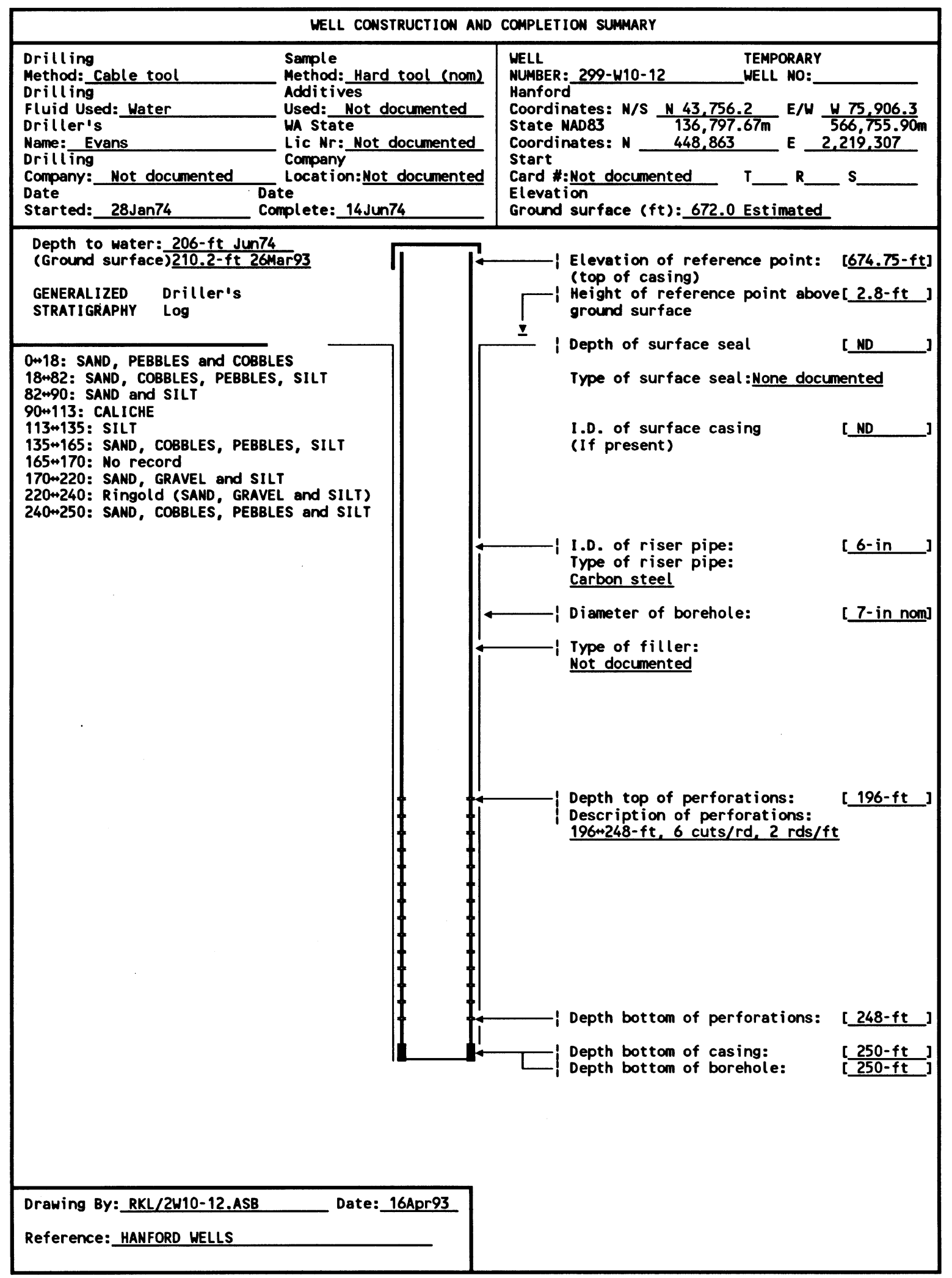


SUMMARY OF CONSTRUCTION DATA AND FIELD OBSERVATIONS

RESOURCE PROTECTION WELL - 299-W10-12

WELL DESIGNATION
CERCLA UNIT
RCRA FACILITY
HANFORD COORDINATES
LAMBERT COORDINATES
DATE DRILLED
DEPTH DRILLED (GS)
MEASURED DEPTH (GS)
DEPTH TO WATER (GS)
CASING DIAMETER
ELEV TOP CASING
ELEV GROUND SURFACE
PERFORATED INTERVAL
SCREENED INTERVAL
COMMENTS

AVAILABLE LOGS
TV SCAN COMMENTS
DATE EVALUATED
EVAL RECOMMENDATION
LISTED USE
PUMP TYPE
MAINTENANCE

299- $\mathbf{1 0 - 1 2}$

200 Aggregate Area Management Study

single Shell Tanks

N 43,756.2 W $75,906.3$ [200W-11Sep90]

$\begin{array}{lll}N & 448,863 & E \\ N & 219,307 & \text { [HANCONV] }\end{array}$

N $136,797.67 \mathrm{~m}$ E $566,755.90 \mathrm{~m}$ [NAD83-11Sep90]

Jun74

250-ft

Not documented

206-ft, Jun74;

210.0-ft, 26 Mar93

6-in carbon steel, $+2.8+250-\mathrm{ft}_{\text {; }}$

675.00-ft, [200w-11Sep90]

672.0-ft, Estimated

6-in casing, 196-248-ft

Not applicable

FIELD INSPECTION, 01Feb90,

6-in carbon steel casing. Capped, not locked

No pad, posts or permanent identification.

Not in radiation zone.

OTHER:

Driller

Not appl icable

Not applicable

Not appl icable

SST Monthly water level measurement, 11Apr90+26Mar93;

Not on water sample schedule

None 


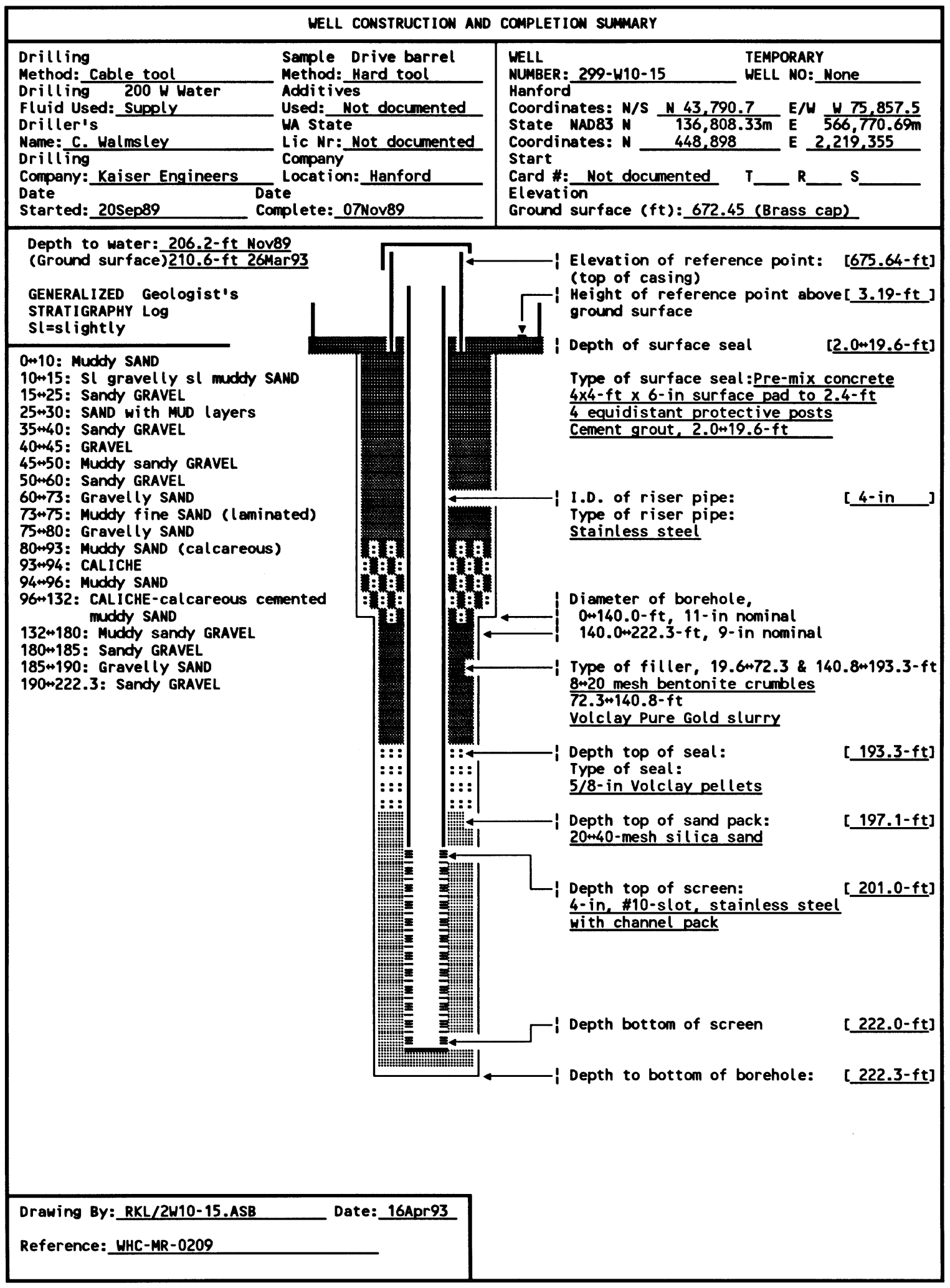




\section{SUMMARY OF CONSTRUCTION DATA AND FIELD OBSERVATIONS}

RESOURCE PROTECTION WELL - 299-W10-15

WELL DESIGNATION
CERCLA UNIT
RCRA FACILITY
HANFORD COORDINATES
LAMBERT COORDINATES :
DATE DRILLED
DEPTH DRILLED (GS)
MEASURED DEPTH (GS)
DEPTH TO WATER (GS)
CASING DIAMETER
ELEV TOP CASING
ELEV GROUND SURFACE :
PERFORATED INTERVAL :
SCREENED INTERVAL :
COMMENTS

299-W10-15

200 Aggregate Area Management Study

single Shell Tanks

N 43,790.7 W $75,857.5$ [200W-12Jan90]

N 448,898 E $2,219,355$ [HANCONV]

N $136,808.33 \mathrm{~m}$ E $566,770.69 \mathrm{~m}$ [NAD83-12Jan90]

Nov89

222.3-ft

Not documented

206.2-ft, Nov90;

210.6-ft, 26Mar93

4-in stainless steel, $+1.0+201.0-\mathrm{ft} ;$
6 -in stainless steel, $+3.19+0.5-\mathrm{ft}$

675.64-ft, [200W-12Jan90]

672.45-ft, Brass cap [200W-12Jan90]

Not appl icable

201.0m222.0-ft, 4-in \#10-slot stainless steel, with channel pack

FIELD INSPECTION, 02Feb90;

6-in stainless steel casing. 4-ft by 4 -ft concrete pad, 4 posts, 1 removable capped and locked, brass cap in pad with well ID.

Not in radiation zone.

OTHER:

AVAILABLE LOGS : Geologist, driller

TV SCAN COMMENTS : Not appl icable

DATE EVALUATED : Not applicable

EVAL RECOMMENDATION : Not appl icable

LISTED USE

SST Monthly water level measurement, 01Dec89426Mar93;

Not on water sample schedule

PUMP TYPE

Hydrostar

MAINTENANCE 


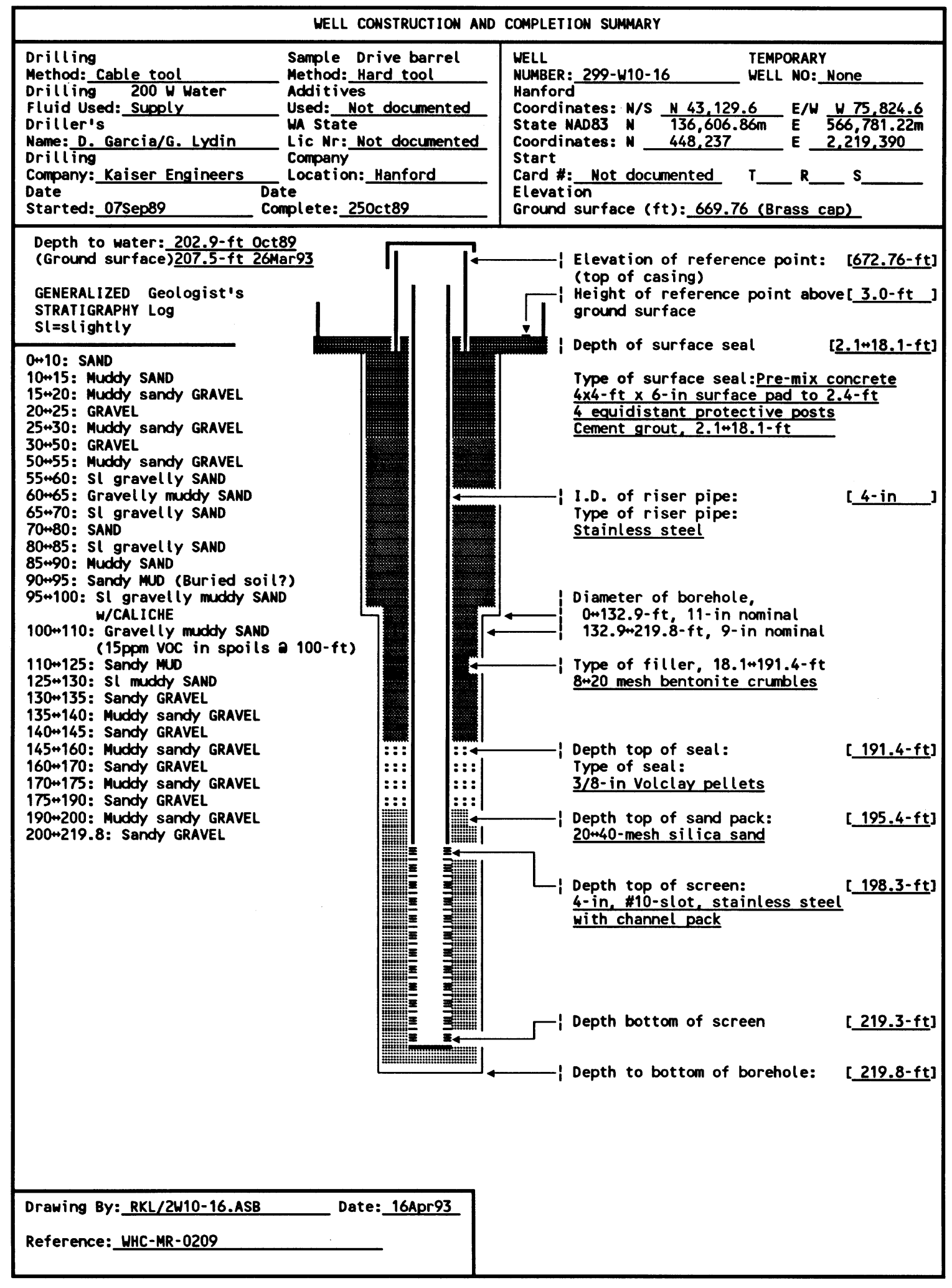

B. 15 


\section{SUMMARY OF CONSTRUCTION DATA AND FIELD OBSERVATIONS}

RESOURCE PROTECTION WELL - 299-W10-16

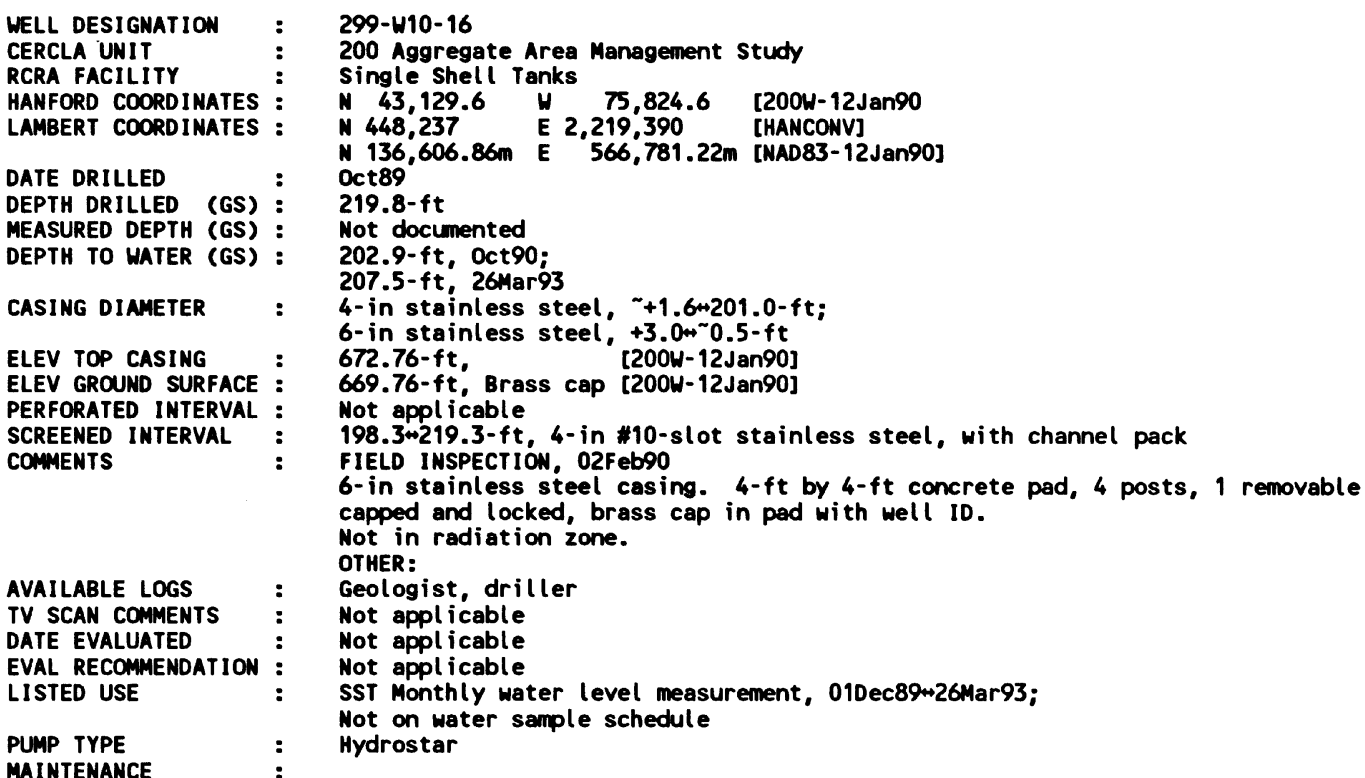




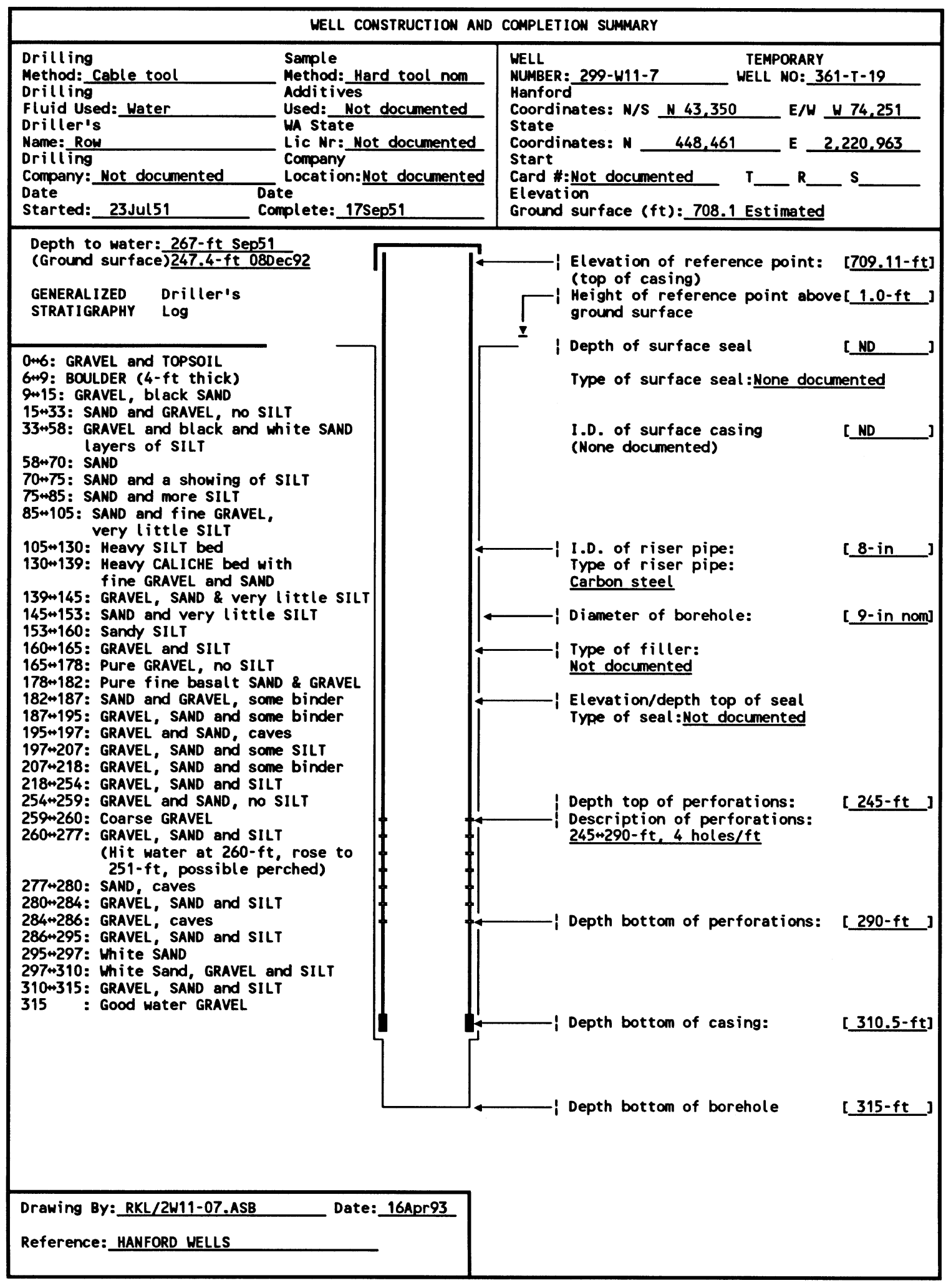


SUMMARY OF CONSTRUCTION DATA AND FIELD OBSERVATIONS RESOURCE PROTECTION WELL - 299-WI1-7

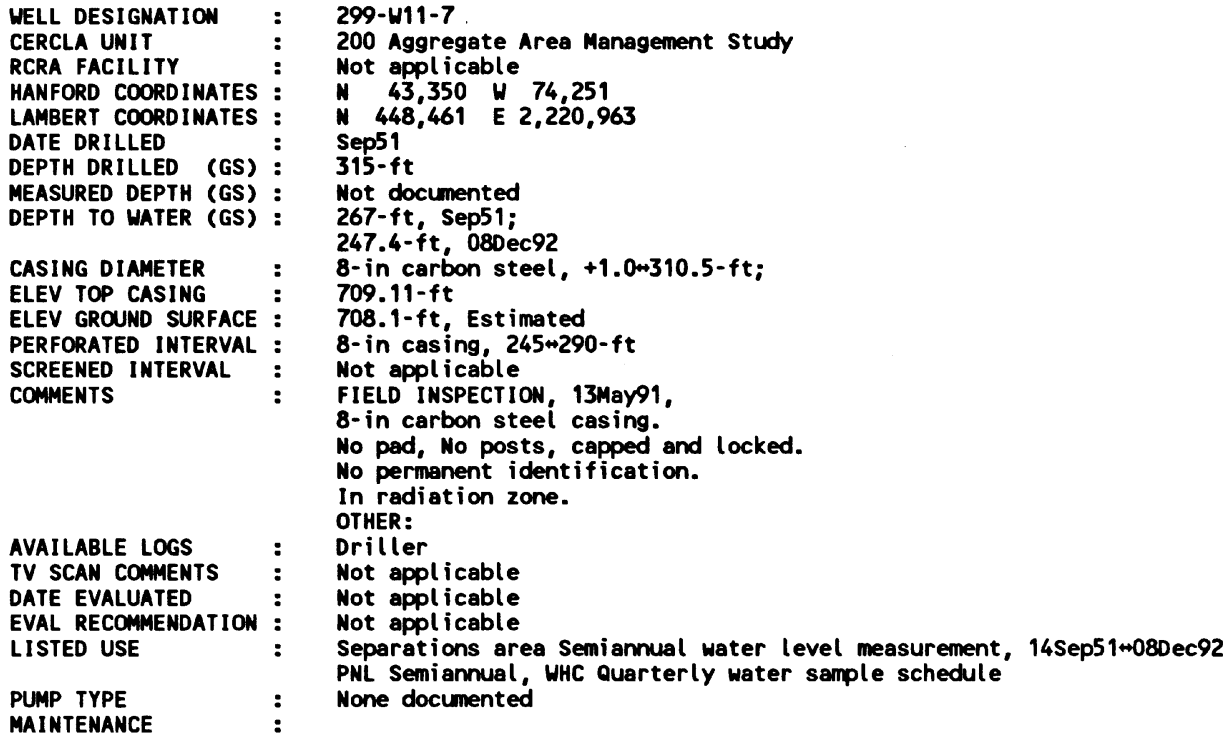




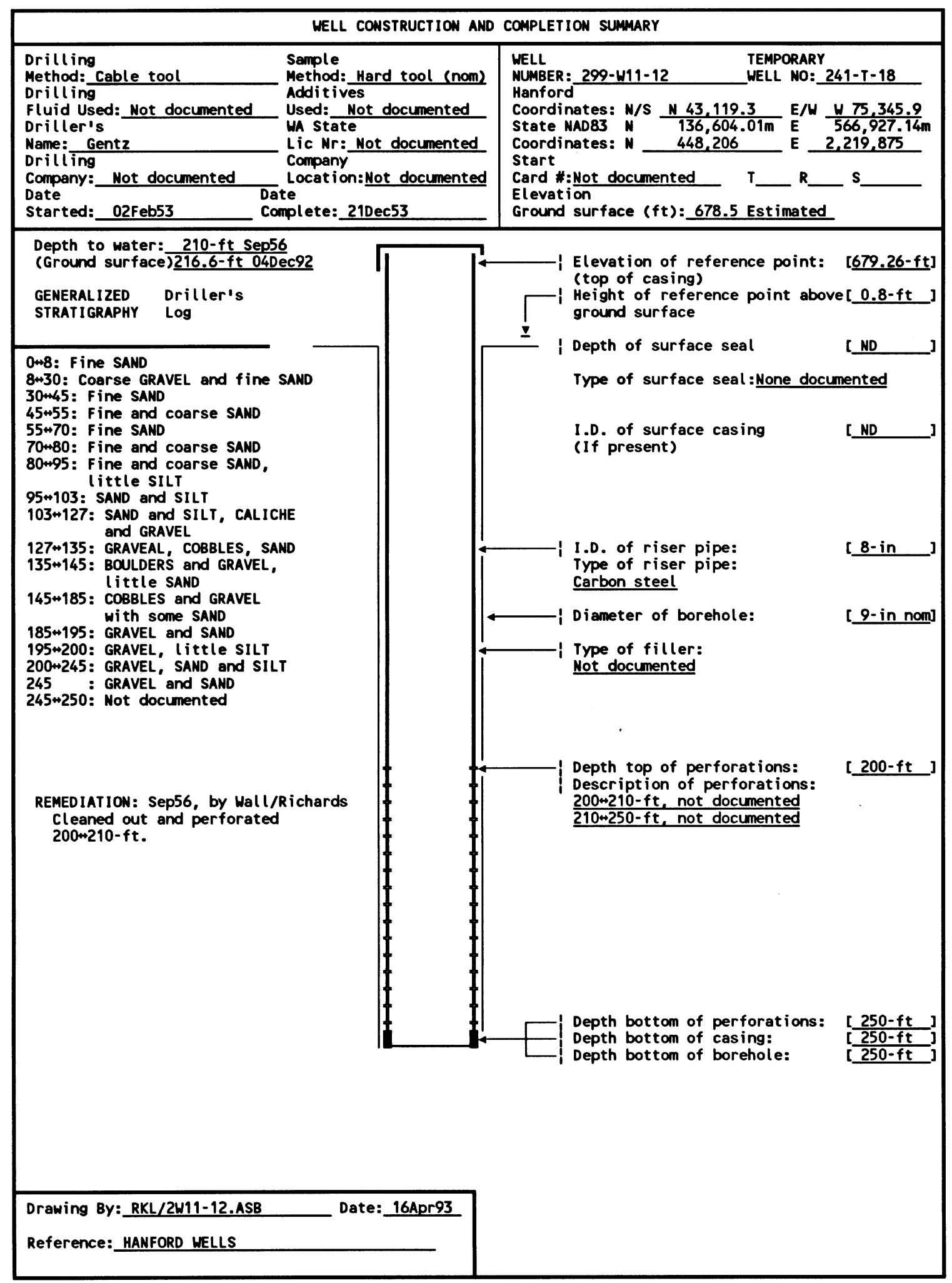




\section{SUMMARY OF CONSTRUCTION DATA AND FIELD OBSERVATIONS} RESOURCE PROTECTION WELL - 299-W11-12

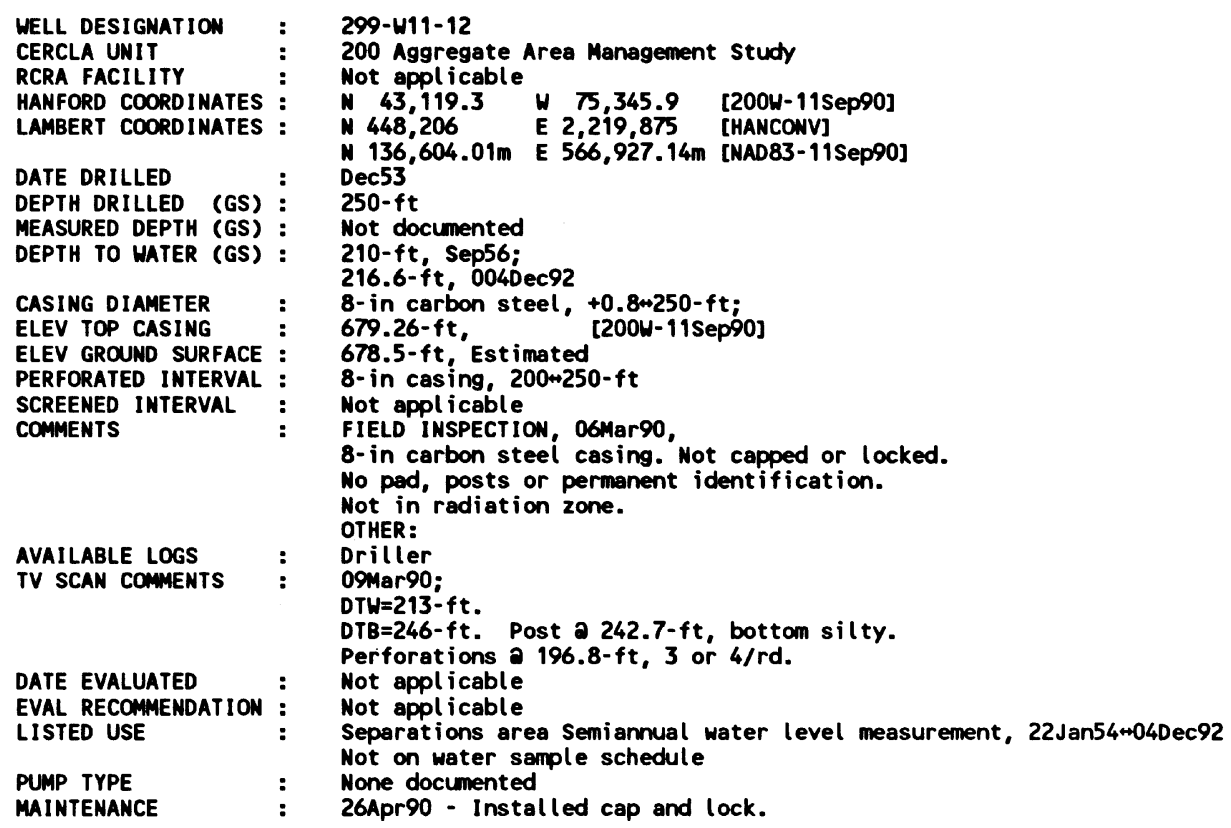




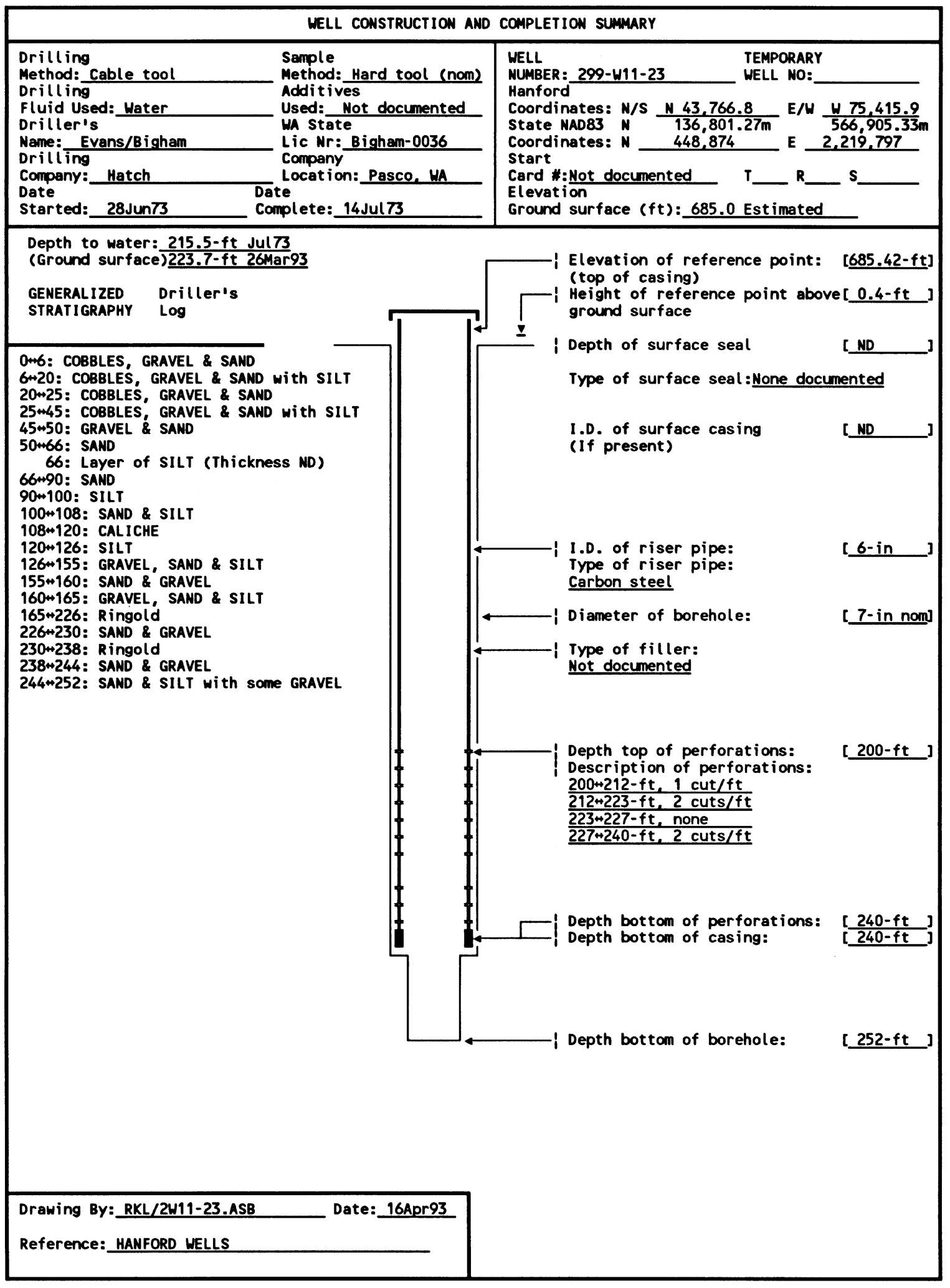




\section{SUMMARY OF CONSTRUCTION DATA AND FIELD OBSERVATIONS}

RESOURCE PROTECTION WELL - 299-W11-23

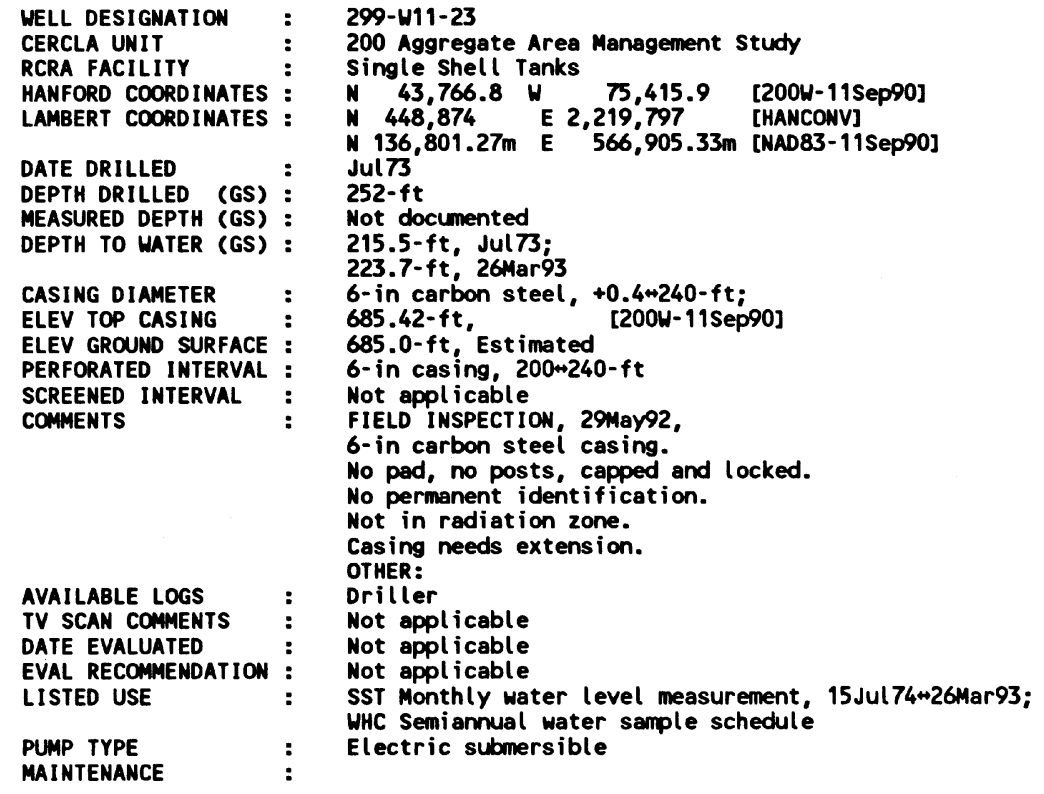




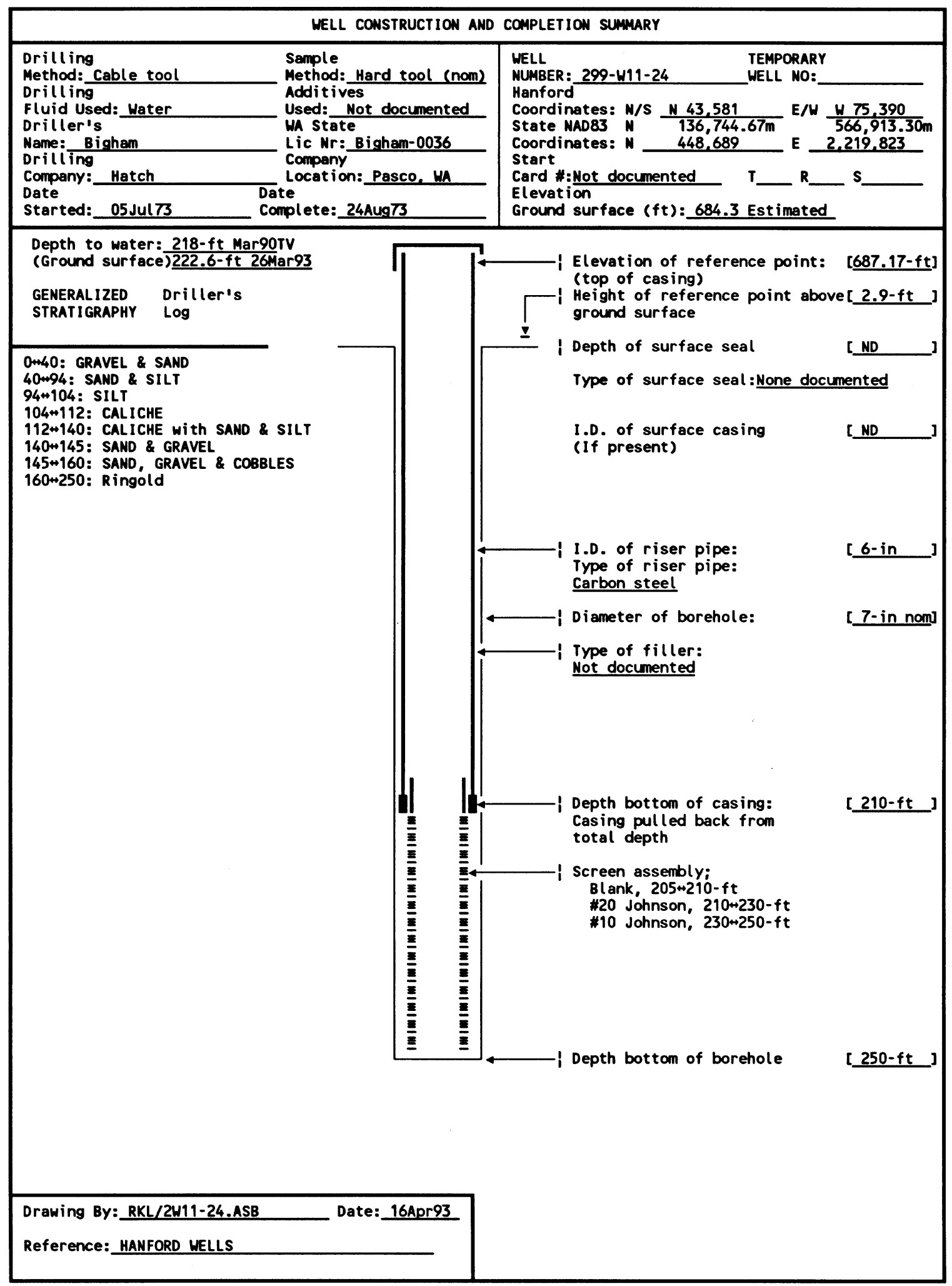


SUMMARY OF CONSTRUCTION DATA AND FIELD OBSERVATIONS RESOURCE PROTECTION WELL - 299-W11-24

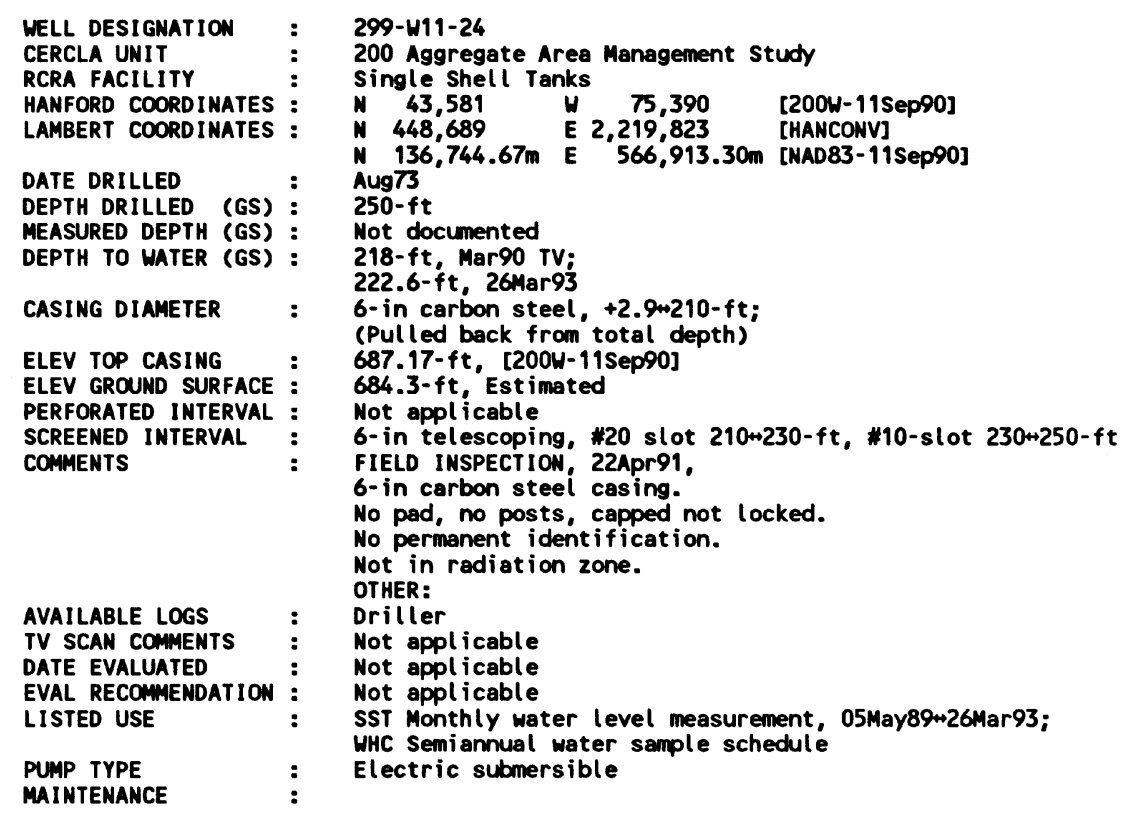




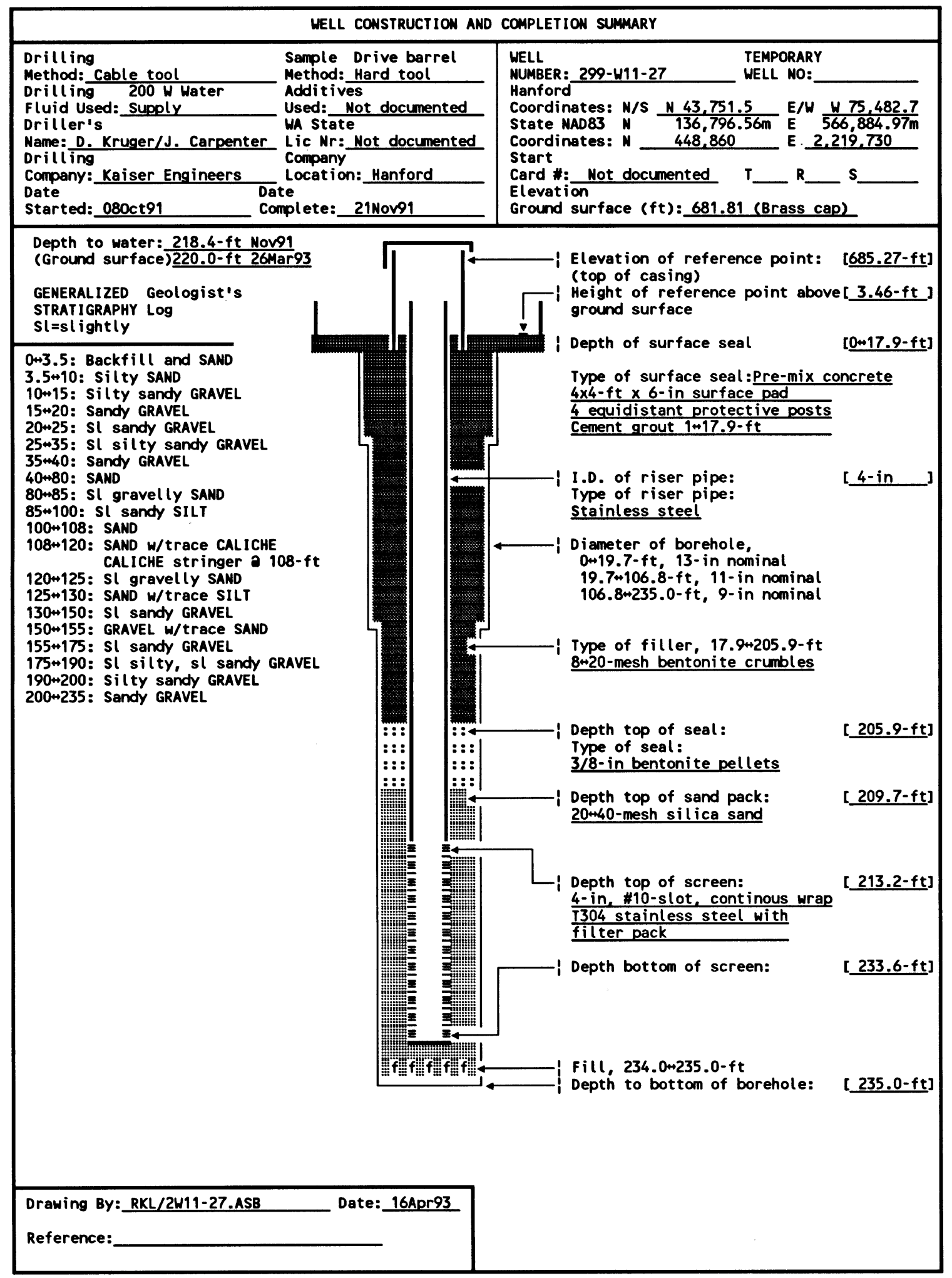


SUMMARY OF CONSTRUCTION DATA AND FIELD OBSERVATIONS

RESOURCE PROTECTION WELL - 299-W11-27

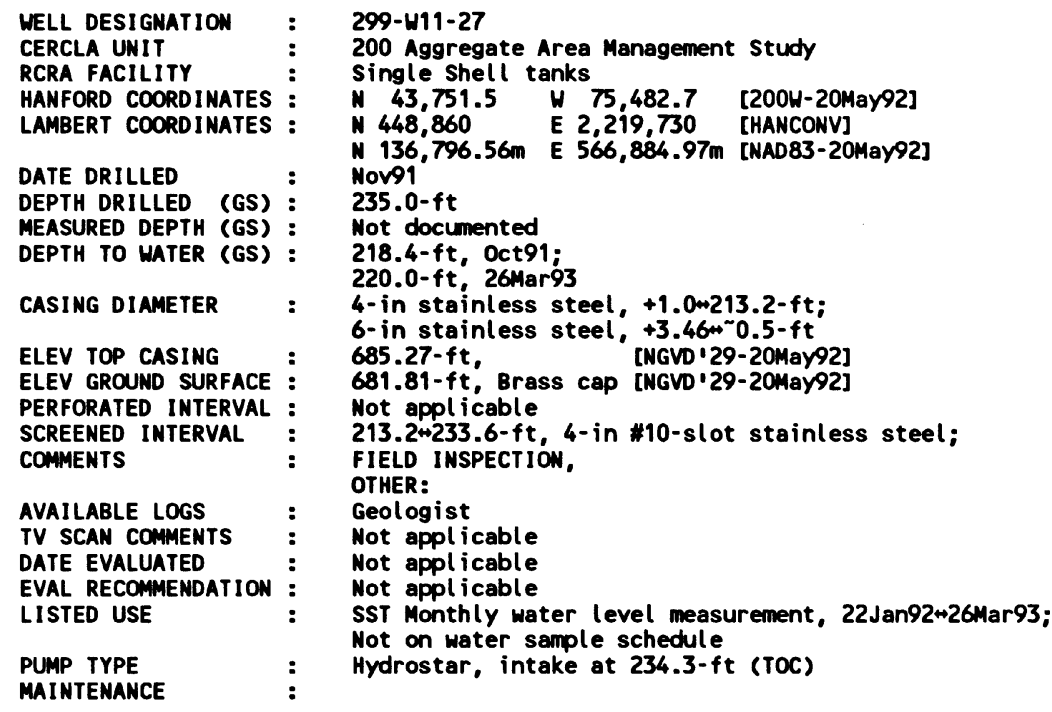




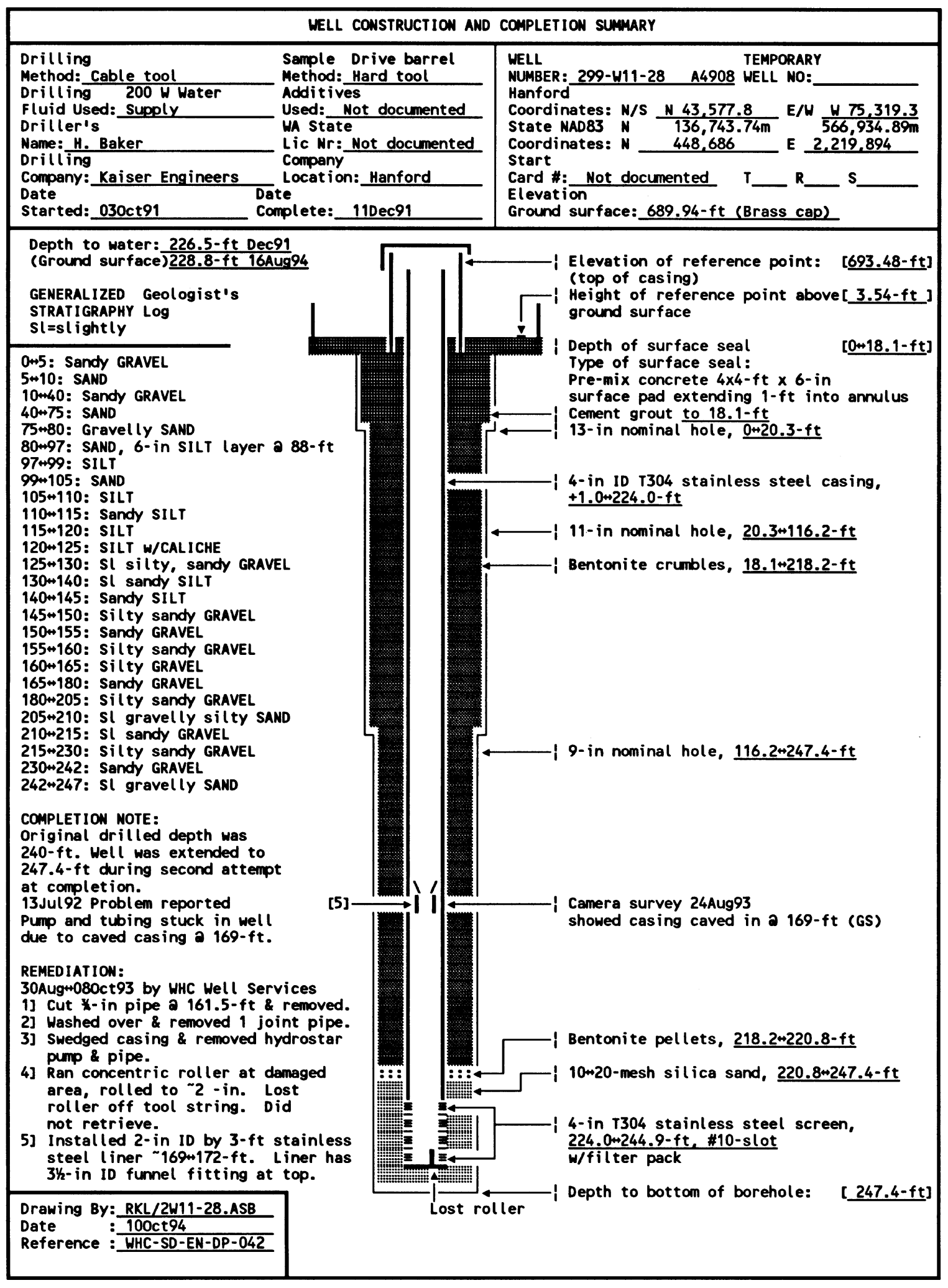


SUMMARY OF CONSTRUCTION DATA AND FIELD OBSERVATIONS RESOURCE PROTECTION WELL - 299-W11-28

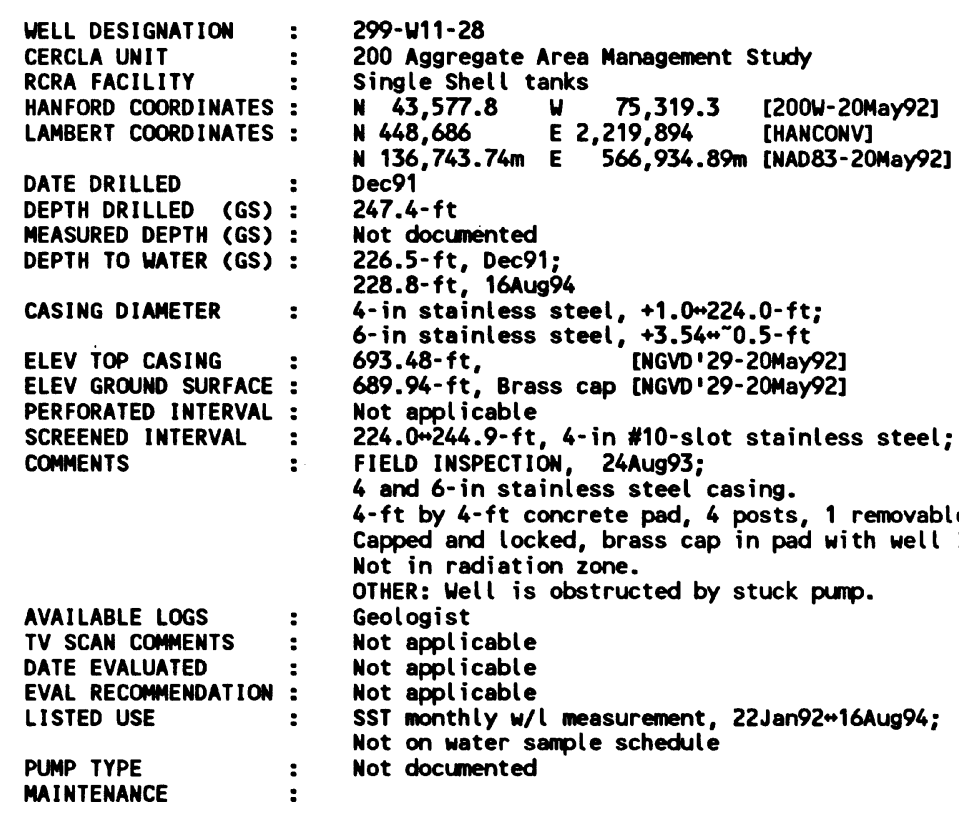




\section{Appendix C}

\section{Monitoring Efficiency Model Output Regarding New Well Installation}




\section{Appendix C}

\section{Monitoring Efficiency Model Output Regarding New Well Installation}

This appendix provides results of computer modeling used to guide locations for new monitoring wells to improve the probability of detecting contamination from Waste Management Area (WMA) T. The model is an analytical Monitoring Efficiency Model, referred to as MEMO, which was developed to assist in design of monitoring well networks (Wilson et al. 1992). The model uses a plume generation routine to compute the size and shape of a plume from hypothetical source locations uniformly distributed within the source area (i.e., waste management area). The model assumes the contaminant is released as a continuous line source to a uniform or homogeneous aquifer. If a contaminant occurrence is more of a short-term transient event, then there is likelihood that the computed monitoring efficiency may be over estimated because less lateral spreading will occur than with a continuous release source.

Major input parameters needed include groundwater flow direction; longitudinal and transverse dispersivities, velocity, buffer zone and well locations. The X-Y coordinates are entered to define well locations, the waste management area boundary and the buffer zone. The buffer zone is used to allow the hypothetical plume to expand to some point beyond the source area boundary. The further away the buffer boundary is set, the greater the lateral spreading that will occur in the vicinity of the line of compliance where the wells are located. Thus, there is a trade off between number of wells needed and the elapsed time when a contaminant plume would be detected. With a narrow buffer zone (boundary set close to the well locations), detection of hypothetical contaminant plumes would occur earlier but requires more wells.

Longitudinal and transverse dispersivities, the parameters that control the extent of spreading of the plume, were previously determined ${ }^{(a)}$ using the observed distribution of the tritium plume in the 200 West Area. These same dispersivities are deemed appropriate for WMA T because the aquifer beneath both the northern and southern part of the 200 West Area is in the same hydrogeologic unit. Other input parameters and the values used for the WMA T computer iterations are defined below.

- X-Y coordinates: State Plane, meters.

- $\mathrm{C}_{\mathrm{D}} / \mathrm{C}_{0}$ : Dilution contour where $\mathrm{C}_{\mathrm{D}}$ is the detection standard selected as the limiting concentration to be detected by a monitoring well, and $\mathrm{C}_{0}$ is the source concentration in groundwater at the location of origin within the waste management area. To provide adequate early warning of a release, the model should be based on a dilution contour for the more mobile potential contaminants at the site. For the

\footnotetext{
(a) Low-Level Waste Burial Grounds RCRA Part B Permit Application, Section 5: Groundwater Monitoring, 903-1201. Prepared for SAIC, Richland, Washington, by Golder Associates Inc., Redmond, Washington, 1990.
} 
WMA T computer simulations, a detection limit of $10 \mathrm{pCi} / \mathrm{L}$ for Tc-99 is used as the detection standard $\left(\mathrm{C}_{\mathrm{D}}\right)$ and $10,000 \mathrm{pCi} / \mathrm{L}$ is used as the source concentration $\left(\mathrm{C}_{0}\right)$, resulting a dilution contour of $\left(\mathrm{C}_{\mathrm{D}} / \mathrm{C}_{0}\right)=(10 \mathrm{pCi} / \mathrm{L}) /(10,000 \mathrm{pCi} / \mathrm{L})=0.001$. This is a reasonable approximation of likely conditions at WMA T.

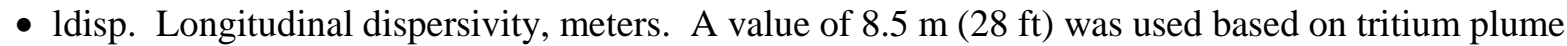
dimensions in the 200 West Area (see Golder Associates 1990, page 102).

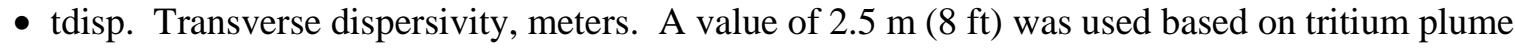
dimensions in the 200 West Area (see Golder Associates 1990, page 102).

- diffc. Effective molecular diffusion coefficient (insignificant for this application so set to zero).

- source width, meters. The length in meters of the initial source dimension (modeled as a line source of the same length spaced evenly over the entire source area). A line source length of $6 \mathrm{~m}$ was used.

- Imb. First order radioactive decay constant. This term was set to zero because no decay was assumed.

- cvel. Average contaminant velocity, meters/day (m/d). A value of $0.1 \mathrm{~m} / \mathrm{d}$ was used for computational purposes.

Output of the MEMO model using existing usable WMA T network (299-W10-4, 299-W10-1, 299-W10-23, 299-W10-8, 299-W10-24, 299-W11-24, and 299-W11-12) is shown in Figure C.1. Flow direction, as inferred from the most recent water table elevations, is almost due east. Input parameters and coordinates used for Figure C.1 are listed in Tables C.1. The shaded areas in Figure C.1 suggest there is a major area of inadequate well coverage at the southeast end of the waste management area and at the northeast corner. The possible sources not likely to be covered by the current network include tank T-111 and the diversion boxes (241-TR-153, 241-T-151, 241-T-152, and 241-T-153) in the southeastern area inside the tank farm fence line (Figure C.1). Three new well locations were added to eliminate the areas of predicted non-coverage (Figure C.2), one at the far northeast corner (well location \#1, near tank T-101 when 299-W11-23 is dry), and two in the southeast corner of the waste management area (well locations \#3 and \#4). One new well is added to replace 299-W11-28 that is going dry (well location \#2). The model results after inclusion of the four new well locations also suggests there may be a need to include an additional well at the far (outside) southeast corner of the $\mathrm{T}$ farm fence line. Printouts for the extended network (i.e., existing useable network plus four additional wells as indicated in Figure C.2), using input parameters values as provided above, are presented in Table C.2.

Based on the above analysis and professional judgment regarding actual site conditions (location of obstructions, contaminant observations, site-specific hydrogeology, etc.), the new well locations were chosen for enhancing near-field spatial coverage for this waste management area. Additional wells may be needed to define mid-field to far-field movement to assess areal extent beyond the waste management area study boundary and to eliminate the remaining non-covered area in the southeastern part of the waste management area. 


\section{C.1 References}

Wilson, C. R., C. M. Einberger, R. L. Jackson and R. B. Mercer. 1992. "Design of Ground-Water Monitoring Networks Using the Monitoring Efficiency Model (MEMO).” Ground Water, 30(6):965-970.

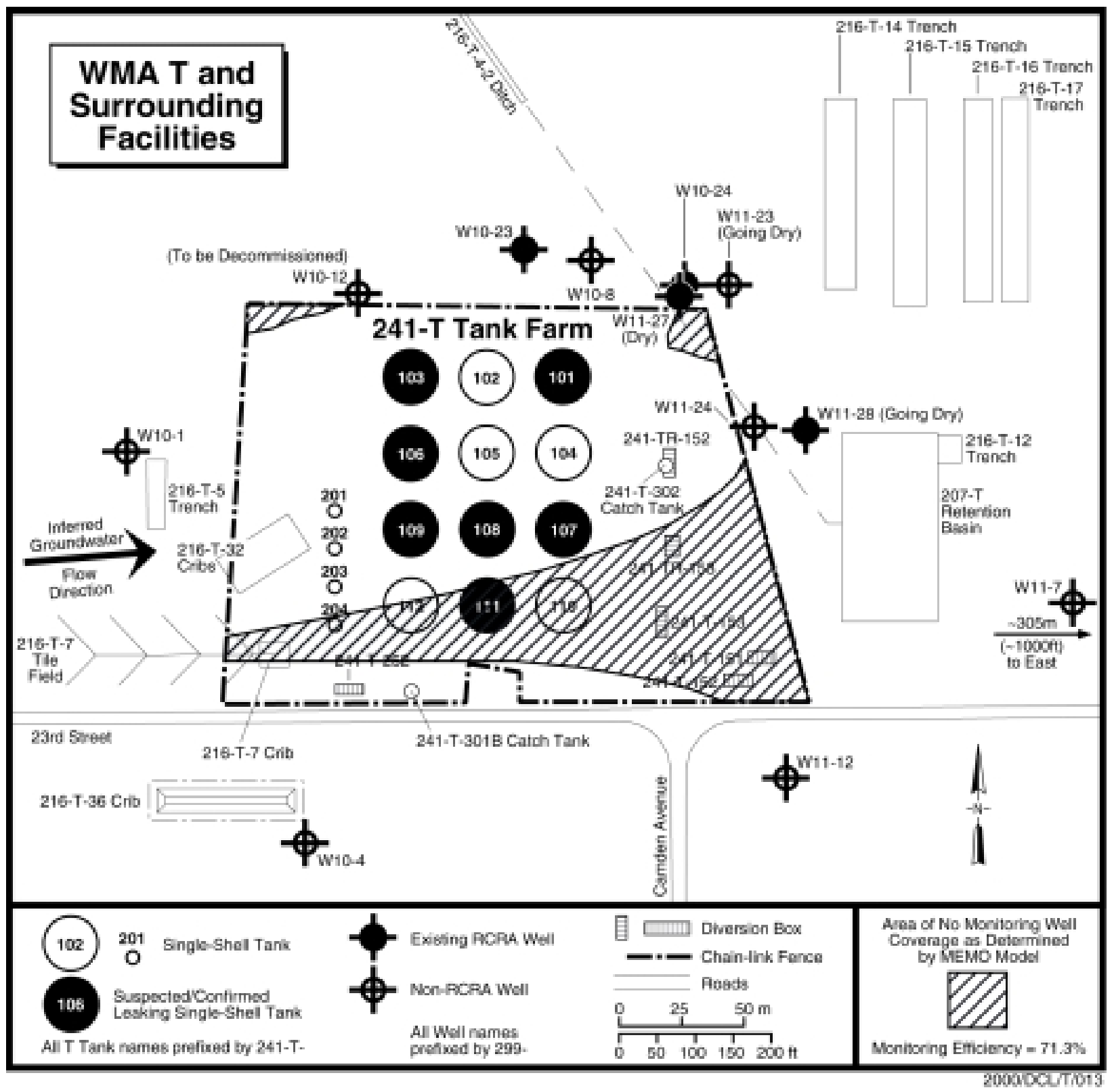

Figure C.1. Existing Monitoring Network Together with Non-covered Areas as Determined by MEMO Model 


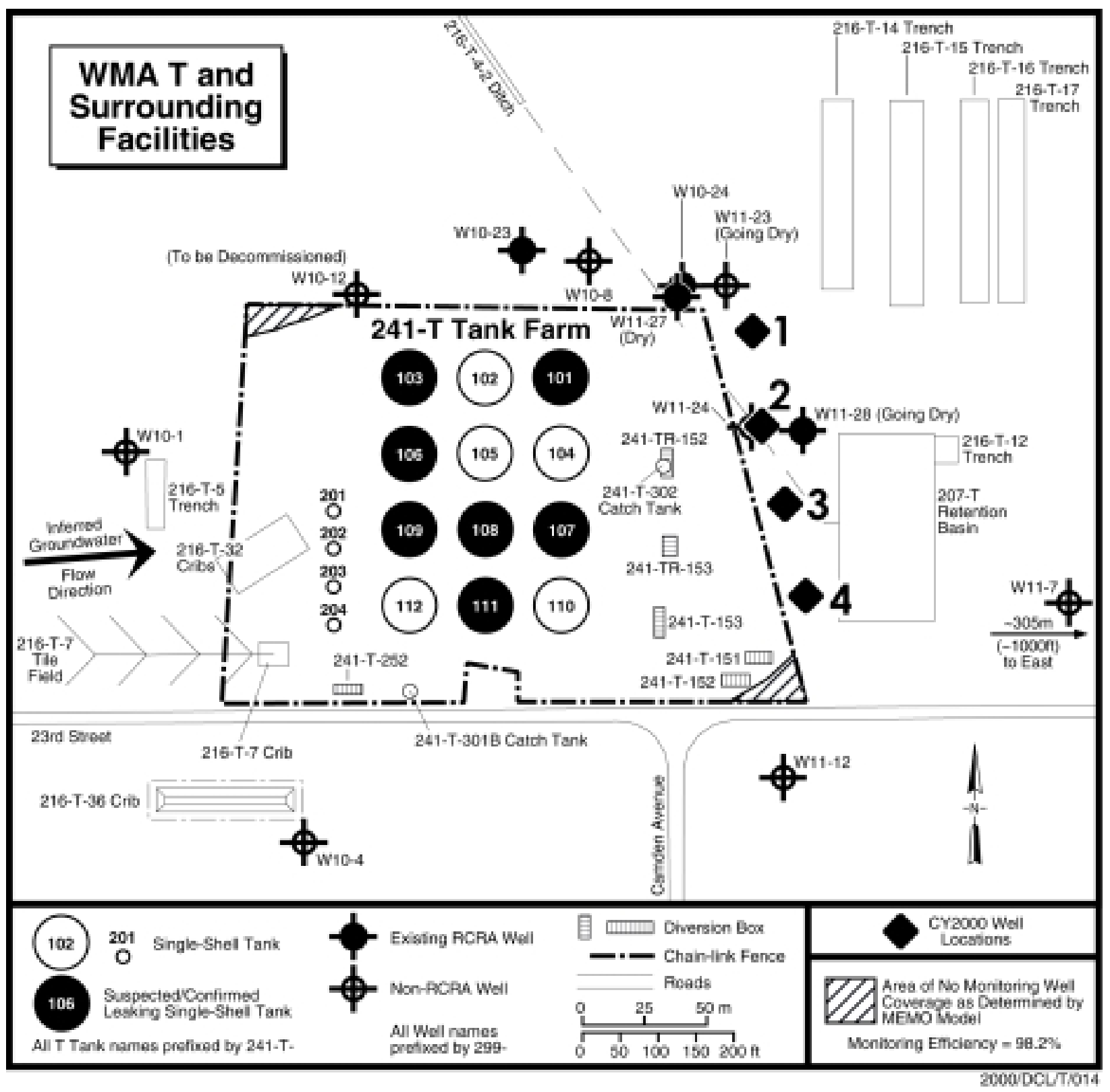

Figure C.2. Existing and New Monitoring Wells with Remaining Non-Covered Areas as Determined by MEMO Model 
Table C.1. Input Parameters and Coordinates for Figure C.1

\begin{tabular}{|c|c|c|}
\hline++ & MEMO Data File & ++ \\
\hline++ & & ++ \\
\hline++ & Monitoring Analysis Package & ++ \\
\hline++ & MAP Version & ++ \\
\hline++ & & ++ \\
\hline++ & GOLDER ASSOCIATES INC. & ++ \\
\hline++ & & ++ \\
\hline++ & Run on $05 / 18 / 00$ at $08: 38: 50$ & ++ \\
\hline
\end{tabular}

$<$ T Tank Farm - RCRA Wells >

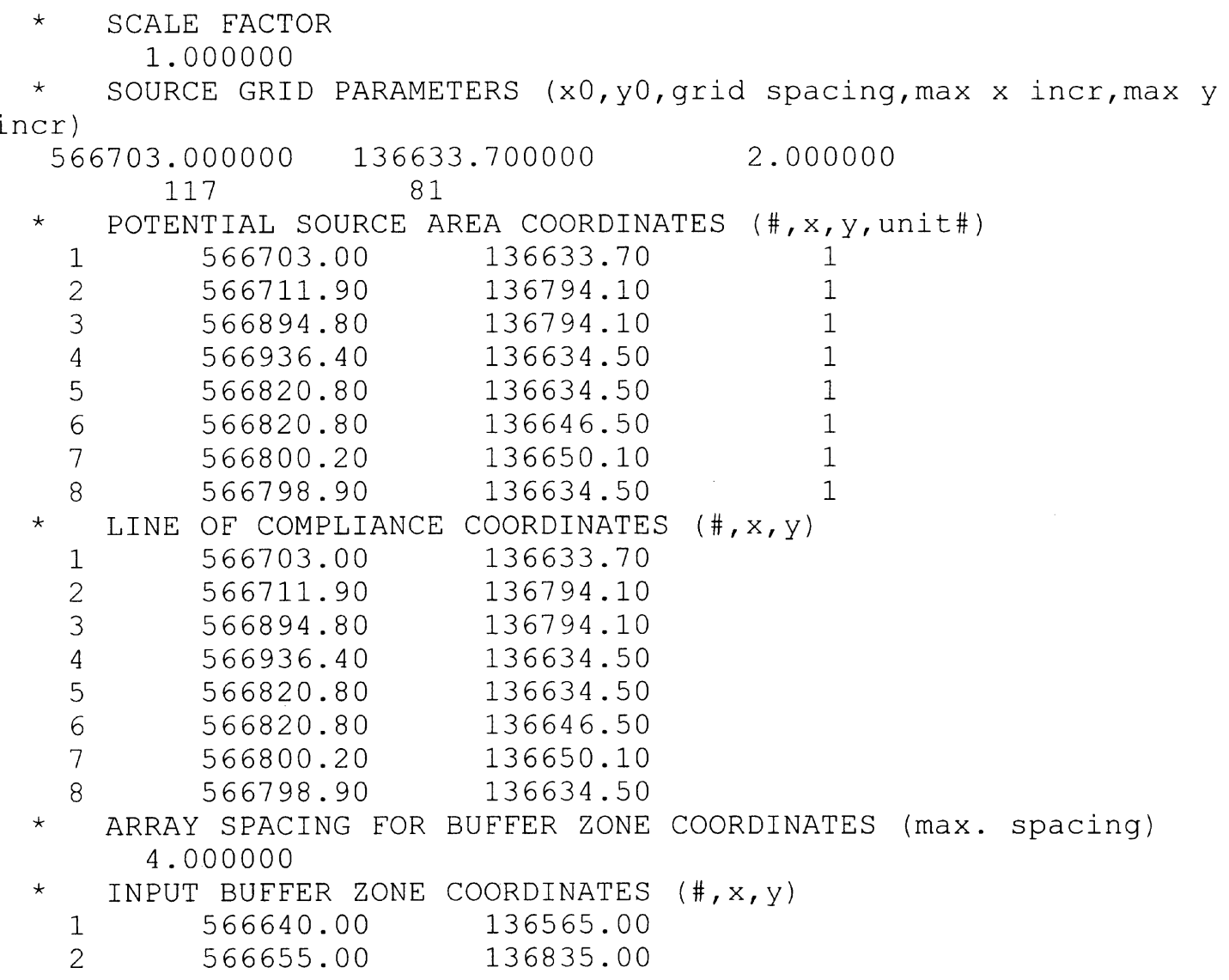


Table C.1. (contd)

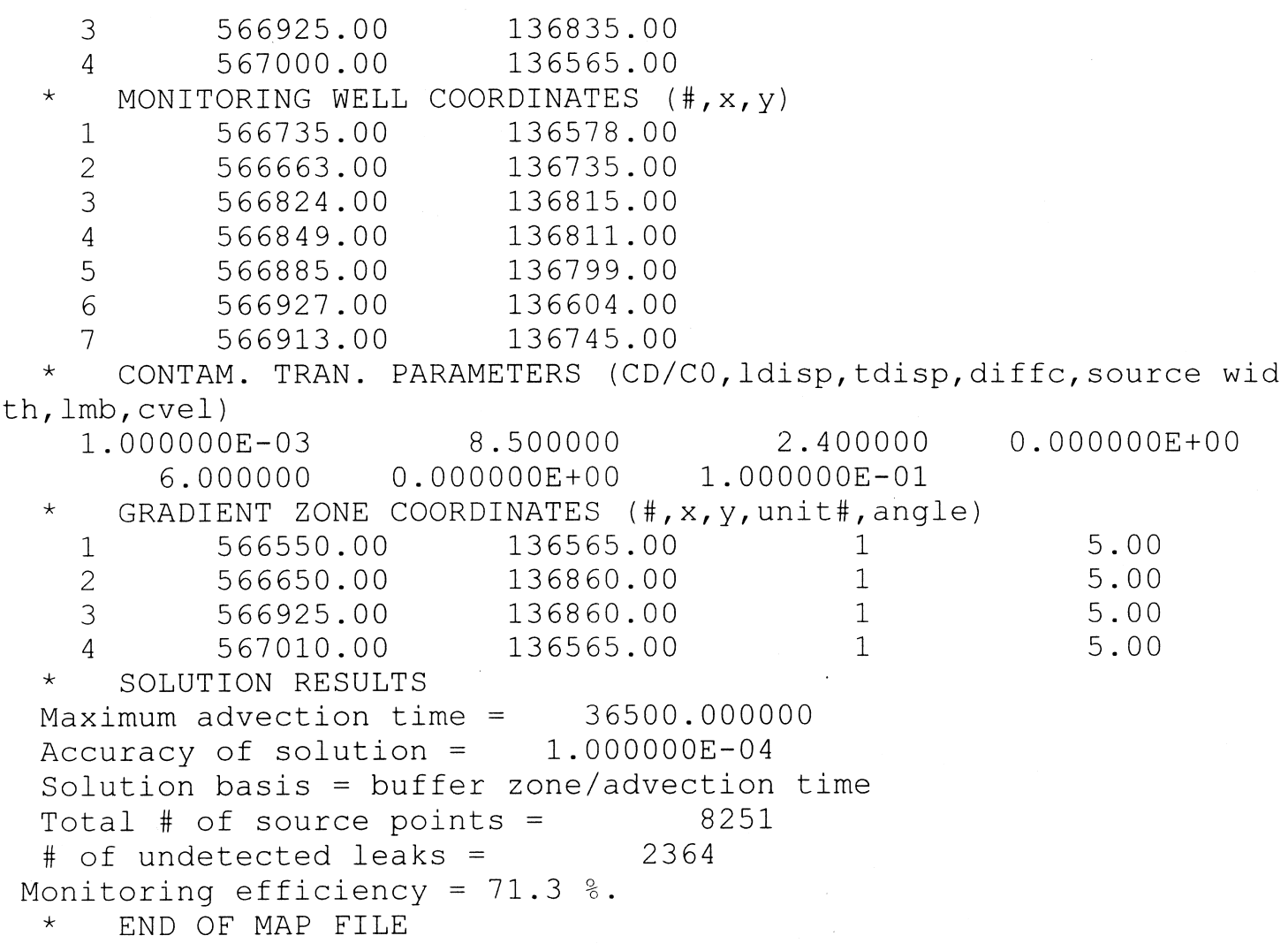


Table C.2. Input Parameters and Coordinates for Figure C.2

\begin{tabular}{|c|c|c|}
\hline++ & MEMO Data File & ++ \\
\hline \multicolumn{2}{|r|}{ 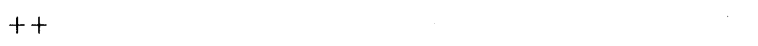 } & \\
\hline++ & Monitoring Analysis Package & \\
\hline \multirow{2}{*}{\multicolumn{2}{|c|}{ MAP Version 1.1}} & \\
\hline & & \\
\hline++ & \multirow[t]{2}{*}{ GOLDER ASSOCIATES INC. } & \\
\hline++ & & \\
\hline++ & Run on $05 / 18 / 00$ at $07: 01: 14$ & \\
\hline
\end{tabular}

$<$ T Tank Farm - RCRA Wells >

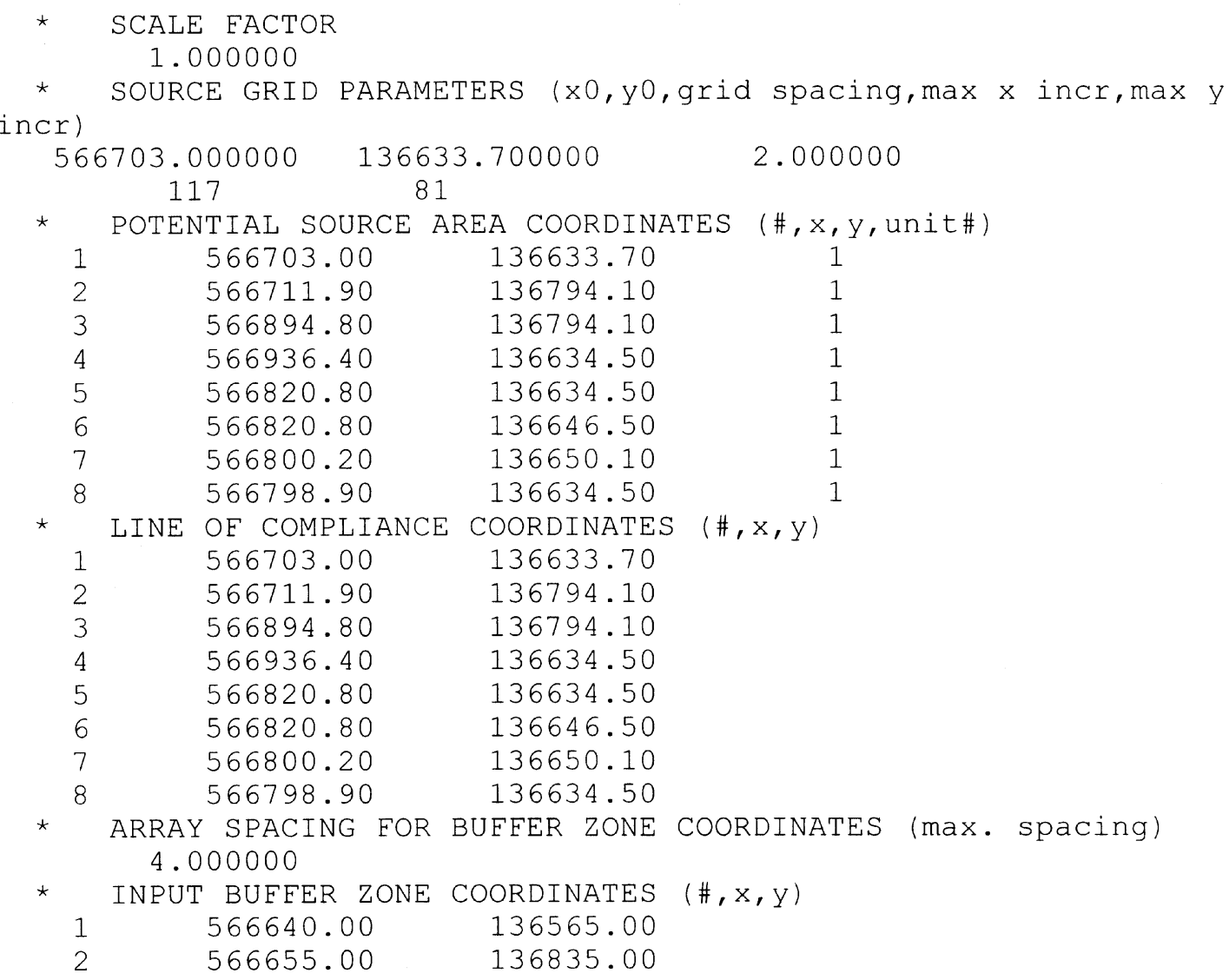

C. 7 
Table C.2. (contd)

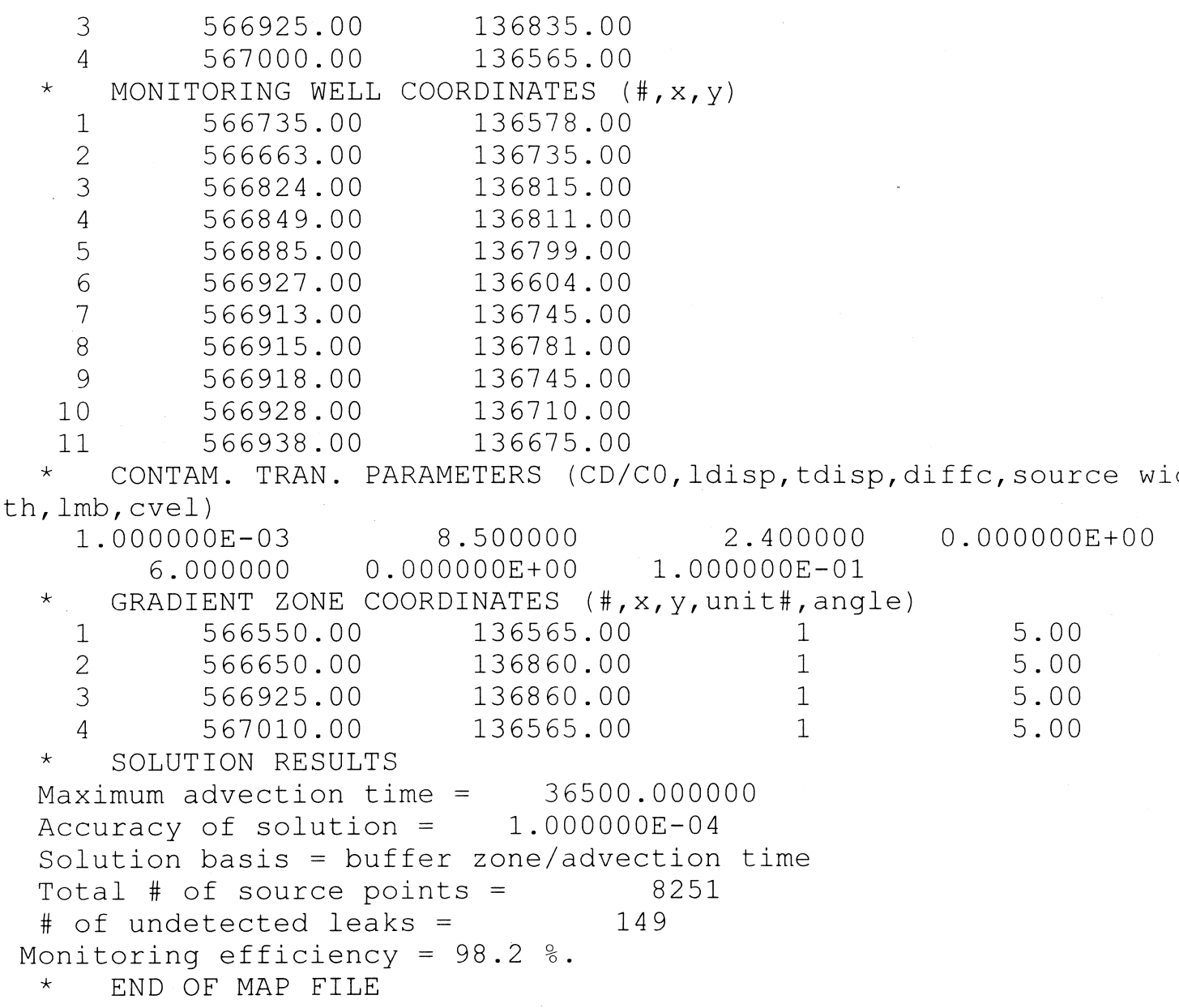




\section{Appendix D}

\section{Preliminary Results for FY-99 and FY-00 Detailed Hydrologic Characterization Tests Conducted in the WMA S-SX, TX-TY, and T}




\section{ข้ำ: Baltelle}

... Putting Technology To Work

Date September 26, 2000

To V.G. Johnson

From

Subject

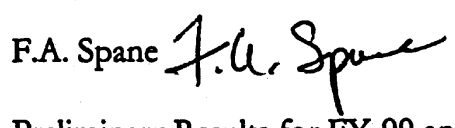

Preliminary Results for FY-99 and FY-00 Detailed Hydrologic Characterization Tests Conducted in the WMA S-SX. TX-TY, and T
Project No. E05158

Internal Distribution

C.J. Chou KG-81

F.N. Hodges

S.P. Luttrell

D.R. Newcomer

P.D. Thome

PFile/LB

This letter report presents preliminary results obtained from detailed hydrologic characterization tests conducted within the WMA S-SX, TX-TY, and T during FY-99 and FY-00. These results are in the process of being formally documented in several PNNL technical reports (e.g., Spane et al. 2000). This letter report is being issued as an interim measure to meet current hydrologic data needs of various WMA projects, prior to formal technical report issuance. The letter report only provides the preliminary results for the various detailed hydrologic characterization test elements, and does not present discussions pertaining to test descriptions, and analytical methods and result comparison. These discussions will be presented in detailed fashion in the subsequent technical reports.

\section{Detailed Hydrologic Characterization Program}

As part of the Hanford Groundwater Monitoring Project, Pacific Northwest National Laboratory conducts detailed hydrologic characterization tests within wells at selected locations to provide information pertaining to the hydraulic properties and groundwater flow characteristics of the unconfined aquifer. The following identifies and briefly describes the various characterization components employed in FY-99 and FY-00, as part of the detailed hydrologic characterization program. Various individual test element activities include:

\section{Groundwater Flow} Characterization:

Barometric Response Evaluation: for quantitative determination of groundwater flow direction and hydraulic gradient conditions

for determining well response characteristics to barometric fluctuations; for estimating vadose zone transmission characteristics; and for removal of barometric pressure effects from hydrologic test responses 
V.G. Johnson

September 26, 2000

Page 2

Slug Testing:

for evaluating well development conditions and to provide preliminary hydraulic property information (e.g., hydraulic conductivity) for design of subsequent hydrologic tests

Tracer-Dilution Test: for determining the vertical distribution of hydraulic conductivity and/or groundwater flow velocity within the well-screen section, and for identifying vertical flow conditions within the well column

Tracer-Pumpback Test: for tracer removal and characterizing effective porosity, an important hydraulic transport parameter

Constant-Rate

conducted in concert with tracer-pumpback phase. Analysis of Pumping Test: drawdown and recovery data provides quantitative, large-scale hydraulic characterization property information, e.g., hydraulic conductivity, storativity, specific yield

Step-Drawdown Test: for determining well efficiency and well loss for the well-screen section; for removal of well loss effects from hydrologic test response

In-Well Vertical for determining the existence of vertical flow within the wellTracer/Test: screen section

Accurate delineation of the prevailing groundwater-flow direction and hydraulic gradient, I, conditions is critical for proper evaluation of groundwater contaminant movement. Within study areas of small size and/or having low gradient conditions, detailed groundwater flow characterization can be difficult. A method that facilitates groundwater flow characterization in such areas is the use of trend-surface analysis of representative monitoring well total head measurements (not well water-level elevation). A description of the use of trend-surface analysis for detailed characterization of groundwater flow conditions is presented in Spane (1999).

Slug testing is designed primarily to provide initial estimates of hydraulic conductivity, $\mathrm{K}$, for the design of subsequent, more quantitative hydrologic tests. At each well, slug tests are conducted using at least two different stress levels to provide information pertaining to well development and possible presence of near-well heterogeneities. A detailed description of the design, performance and analysis of slug test characterizations is presented in Butler et al. (1994) and Butler (1997).

Tracer dilution and tracer pumpack/constant-rate pumping and recovery tests are conducted at single-well sites. For the tracer-dilution test, a bromide solution of known concentration is circulated/mixed within the well-screen section. The decline of tracer concentration (i.e., "dilution") with time within the well screen is monitored directly using a vertical array of bromide specific-ion electrode probes located at known depth intervals. Based on the dilution 
V.G. Johnson

September 26, 2000

Page 3

characteristics observed, the vertical distribution (i.e., heterogeneity) of hydraulic properties and/or flow velocity can be estimated for the formation within the well-screen section. The presence of vertical flow within the well screen can also be identified from the probe/depth dilution response pattern. A description of the performance and analysis of tracer-dilution test characterization investigations is provided in Halevy et al. (1966), Hall et al. (1991), and Hall (1993).

For the tracer pumpback, a constant-rate pumping test is initiated after the average tracer concentration has decreased (i.e., diluted) to a sufficient level within the well screen (usually a 1 to 2 order of magnitude reduction from the original tracer concentration). The objective of the pumpback test is to "capture" the tracer that has moved from the well into the surrounding aquifer. Tracer recovery is monitored by measuring the tracer concentration in water pumped from the well. The time required to recover the centroid of tracer mass/concentration provides information of the aquifer effective porosity, $\mathrm{n}_{\mathrm{e}}$. Effective porosity is a primary hydrologic parameter controlling contaminant transport. Once estimates for $n_{e}, K$, and I have been determined, the average aquifer groundwater flow velocity, $v_{2}$, can also be calculated.

The constant-rate pumping test may be extended for a time duration longer than required for capturing the tracer centroid. The extended pumping time enables quantitative large-scale characterization of the surrounding hydraulic properties. The time required to obtain representative hydrologic property results can be determined by using diagnostic derivative analysis results of the drawdown data obtained from the pumped and nearby observation well locations. A detailed description of the use of derivative analysis techniques is provided in Spane (1993) and Spane and Wurstner (1993).

Following termination of the constant-rate pumping test phase, the recovery of water levels within the pumped well and surrounding observation wells can also be monitored. The time required for recovery monitoring can be assessed in a manner similar to drawdown data collected during the pumping phase, through the use of diagnostic derivative analysis. For general planning purposes, however, recovery monitoring should be maintained for a period equal to the pumping period and preferably longer. Analysis of the associated pressure drawdown and recovery responses at the surrounding observation wells provides the basis for determining standard, large-scale hydraulic properties within the tested aquifer. These hydraulic properties include: horizontal conductivity $\left(K_{h}\right)$, transmissivity $(T)$, storativity $(S)$, and specific yield $\left(S_{y}\right)$. In addition, detailed hydrologic property characterization obtained from compositely analyzing drawdown and recovery data from multiple observation wells include: vertical anisotropy $\left(\mathrm{K}_{\mathrm{v}} / \mathrm{K}_{\mathrm{h}}\right)$ and horizontal anisotropy $\left(\mathrm{K}_{\mathrm{hx}} / \mathrm{K}_{\mathrm{hy}}\right)$. The vertical and horizontal anisotropy parameters are the principal hydraulic parameters controlling the directional contaminant transport within the local area. 
V.G. Johnson

September 26, 2000

Page 4

A group of tables is presented in this letter report that summarize the results from various detailed hydraulic characterization activities. Table 1 provides a summary of the various detailed hydraulic characterization elements. Table 2 lists the preliminary analysis results for hydraulic conductivity and transmissivity determined from slug tests and constant-rate pumping tests. Table 3 presents pertinent information pertaining to tracer-dilution testing, and estimates for lateral groundwater flow velocity within the well screen, $v_{w}$. Table 4 presents results of tracer pumpback testing and associated estimates for effective porosity, $\mathrm{n}_{\mathrm{e}}$, and average aquifer groundwater flow velocity, $\mathrm{v}_{\mathrm{a}}$. Table 5 lists the results of groundwater flow characterization (hydraulic gradient, I, and groundwater flow direction), based on trend-surface analysis, for the various well sites selected for tracer testing.

\section{Data Discussion}

\section{Table 2}

Table 2 presents estimates obtained from slug testing and constant-rate pumping tests. The range for $\mathrm{K}$ listed for slug tests represent the average $\mathrm{K}$ value as determined using the Bouwer and Rice method and the type-curve matching procedure. Constant-rate pumping test results include the analysis of drawdown and/or recovery data using the methods identified previously. A close correspondence in estimates for $\mathrm{K}$ is evident between the two test methods. It should also be noted that the test analysis was completed independently by different analysts, i.e., F.A. Spane: slug tests and P.D. Thorne: constant-rate pumping tests.

\section{Table 3}

Table 3 lists pertinent information pertaining to the tracer-dilution tests performed. Several wells exhibited vertical flow conditions (denoted by VF in the table), which largely invalidate the results of the test. The vertical flow conditions detected during the tracer-dilution testing (i.e., well 299W10-26: downward; well 299-W14-13: downward; and 299-W22-49: upward) were also corroborated independently directly using electromagnetic vertical flowmeter surveys conducted at these wells, as reported in Waldrop and Pearson (2000).

It should be noted that the $v_{w}$ estimates based on the tracer-dilution tests are strictly for in-well groundwater flow conditions. The relationship between $v_{w}$ and aquifer groundwater flow velocity, $\mathrm{v}_{2,}$, is shown in equation (1) below:

$$
v_{w}=v_{\mathrm{a}} \mathrm{n}_{\mathrm{e}} \propto
$$

$$
\text { where, } \propto \quad=\quad \begin{aligned}
& \text { groundwater flow distortion factor; } \\
& \text { dimensionless, common range } 0.5 \text { to } 4
\end{aligned}
$$


V.G. Johnson

September 26, 2000

Page 5

Average well flow velocities ranged between 0.007 to $0.311 \mathrm{~m} / \mathrm{d}$. It should be noted that the lowest average value of $0.007 \mathrm{~m} / \mathrm{d}$ recorded at well 299-W22-48 (WMA S-SX), is a result of averaging depth/well velocity conditions that indicate very little flow within the lower part of the well screen. The value of $0.023 \mathrm{~m} / \mathrm{d}$ indicated for the well screen maybe more reflective of actual aquifer conditions. The highest value of $0.311 \mathrm{~m} / \mathrm{d}$ calculated for well 299-W15-41 (WMA T) is higher than expected, and may be the result of extraneous hydrologic effects imposed by the nearby 200-ZP-1 pump and treat facility. This well location is well within the potential radius of influence distances reported in Spane and Thorne (2000) and, therefore a possible cause for the observed elevated in-well flow velocities.

To assess the repeatability of the tracer-dilution test results, two separate tests were conducted at well 299-W22-50. A comparison of the tests indicates small, but discernable differences in the associated $v_{w}$ estimates, i.e., Test \#1 = $0.066 \mathrm{~m} / \mathrm{d}$; Test $\# 2=0.046 \mathrm{~m} / \mathrm{d}$. Results for Test \#2 are considered to be more representative based on the lower initial tracer concentration used (i.e., possible tracer concentration bias), and the longer tracer-dilution period exhibited.

A comparison of the observed depth/well velocity profiles provided information about permeability distribution within the well-screen sections at four of the wells. At wells 299-W10-24 (WMA TX-TY)and -W15-41 (WMA T) the highest flow velocities (and inferred permeabilities) were exhibited near the middle of the screen, with lowest flow velocities indicated near the top. Conversely, for well 299-W22-48 (WMA S-SX), the highest flow velocity was denoted near the top, with essentially little to no flow indicated for the lower part of the well screen. For well 299W22-50 (southern boundary of WMA S-SX), relatively uniform depth/well velocity profiles were exhibited, indicating homogeneous conditions throughout the well-screen section. This condition was indicated for both tests conducted at the well site.

\section{Table 4}

Table 4 lists pertinent information pertaining to the tracer pumpback tests performed. As noted previously, several wells exhibited vertical flow conditions during the tracer-dilution tests (denoted by VF in the table). The fact that tracer only was emplaced into the aquifer within a small portion of the well screen, seriously impacts the assumptions of the test (which will be discussed in detail in the subsequent PNNL technical report). The tracer pumpback results for those wells affected by vertical flow conditions are highly questionable, and should not be used for quantitative assessment. The estimates calculated from the tests, however, are provided in the table (in parentheses) for only comparison/informational purposes.

Estimates for $n_{e}$ for the reportable tests ranged between 0.068 and 0.257 (note: Test \#2 for well 299-W22-50 is believed more representative, due to the fact that longer tracer drift times are less affected by well effects). This range for $n_{e}$ falls within the common range usually reported for 
V.G. Johnson

September 26, 2000

Page 6

semi-consolidated to unconsolidated alluvial aquifers of 0.05 to 0.30 , and brackets the large-scale values for specific yield, $S_{y}\left(S_{y} \approx n_{e}\right)$ of 0.11 and 0.17 , reported in Newcomb and Strand (1953) and Wurstner et al. (1995), respectively for the 200 -West Area. These large-scale analysis values were based on analyzing the growth and decline of the groundwater mound beneath the 200-West Area, that were associated with water disposal practices in the area.

Estimates for $\mathrm{v}_{\mathrm{a}}$ for the reportable tests ranged between 0.013 and $0.374 \mathrm{~m} / \mathrm{d}$, and generally fall within a factor of 2 of the calculated in-well flow velocities, $v_{w}$. As noted previously for $v_{w}$ at well 299-W15-41, the observed estimate for $v_{i}$ of $0.374 \mathrm{~m} / \mathrm{d}$ at this well site may be elevated due to affects imposed by operation of the adjacent 200-ZP-1 pump and treat system.

\section{Table 5}

Table 5 lists groundwater flow characterization results pertaining to determination of groundwater-flow direction and hydraulic gradient, I, conditions at the various test sites during the times of tracer testing. Groundwater-flow direction and hydraulic gradient were calculated using the commercially available WATER-VEL (In-Situ, Inc. 1991) software program. Water-level elevations from neighboring, representative wells were used as input with the WATER-VEL program to calculate groundwater-flow direction and hydraulic gradient conditions during the detailed characterization period. The program utilizes a linear, two-dimensional trend surface (least squares) to randomly located hydrologic head or water-level elevation input data. This method is similar also to the linear approximation technique described by Abriola and Pinder (1982) and Kelly and Bogardi (1989). A report that demonstrates the use of the WATER-VEL program for calculation of groundwater-flow velocity and direction is presented in Gilmore et al. (1992) and Spane (1999).

Calculations of $I$ listed in Table 5 were used for estimates of $n_{e}$ and $v_{2}$ shown in Table 4. The indicated easterly groundwater flow directions for WMA S-SX and T sites and the southerly groundwater flow direction for the TX-TY directions is consistent with previous generalizations presented in Hartman et al. (1999) for these areas.

\section{References}

Butler, J.J., G.C. Bohling, Z. Hyder, and C.D. McElwee. 1994. The Use of Slug Tests to Describe Vertical Variations in Hydraulic Conductivity. Journal of Hydrology, Vol 156, pp. 137-162.

Butler, J.J. 1997. The Design. Performance, and Analysis of Slug Tests. Lewis Publishers, Boca Raton, Florida, 252 p.

Halevy, E., H. Moser, O. Zellhofer, and A. Zuber. 1966. Borehole Dilution Techniques - A Critical Review, in International Atomic Energy Agency, Isotopes in Hydrology, Vienna, Austria

Hall, S.H., S.P. Luttrell, and W.E. Cronin. 1991. A Method for Estimating Effective Porosity and Ground-Water Velocity. Ground Water, Vol. 29, No. 2, pp. 171-174. 
V.G. Johnson

September 26, 2000

Page 7

Hall, S.H. 1993. Single Well Tracer Tests in Aquifer Characterization. Ground Water Monitoring \& Remediation, Vol. 13, No. 2, pp. 118-124.

Hartman MJ. 1999. Hanford Site Groundwater Monitoring for Fiscal Year 1998. PNNL-12086, Pacific Northwest National Laboratory, Richland, Washington.

Newcomb R.C. and J.R. Strand. 1953. Geology and Ground-Water Characteristics of the Hanford reservation of the U.S. Atomic Energy Commission. Washington. U.S. Geological Survey Administrative Report WP-8, U.S. Geological Survey, Washington, D.C.

Spane, F.A., Jr. and P.D. Thorne. 1995. Comparison of Constant-Rate Pumping Test and Slug Interference Test Results at the Hanford Site B Pond Multilevel Test Facility. Pacific Northwest Laboratory, PNL-10835, Richland, Washington.

Spane, F.A., Jr. and P.D. Thorne. 2000. Analysis of the Hydrologic Response Associated with Shutdown and Restart of the 200-ZP-1 Pump and Treat System. (in progress), Pacific Northwest National Laboratory, Richland, Washington.

Spane, F.A., Jr., P.D. Thorne, and D.R. Newcomer. 2000. Results of Detailed Hydrologic Characterization Tests - FY 1999. (in progress), Pacific Northwest National Laboratory, Richland, Washington.

Spane, F.A., Jr. and S.K. Wurstner. 1993. DERIV: A Program for Calculating Pressure Derivatives for Use in Hydraulic Test Analysis. Ground Water, Vol. 31, No. 5, pp. 814-822; published also as Pacific Northwest Laboratory, PNL-SA-21569 (1992).

Spane, F.A., Jr. 1993. Selected Hydraulic Test Analysis Techniques for Constant-Rate Discharge Tests. Pacific Northwest Laboratory, PNL-8539, Richland, Washington.

Spane, F.A., Jr. 1999. Effects of Barometric Fluctuations on Well Water-Level Measurements and Aquifer Test Data. PNNL-13078, Pacific Northwest National Laboratory, Richland, Washington.

Wurstner S.K., P.D. Thorne, M.A. Chamness, M.D. Freshley, and M.D. Williams. 1995. Development of a Three-Dimensional Ground-Water Model of the Hanford Site Unconfined Aquifer System: FY 1995 status report. PNL-10886, Pacific Northwest Laboratory, Richland, Washington.

Waldrop, W.R. and H.S. Pearson. 2000. Results of Field Tests with the Electromagnetic Borehole Elowmeter at the Pacific Northwest National Laboratory Richland. Washington. Quantum Engineering Corporation, Loudon Tennessee. 
V.G. Johnson

September 26, 2000

Page 8

Table 1. Detailed Hydrologic Characterization Elements

\begin{tabular}{|c|c|c|}
\hline 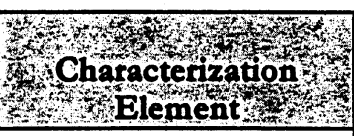 & 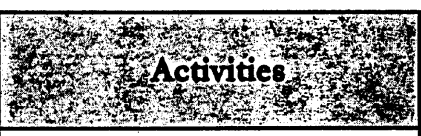 & 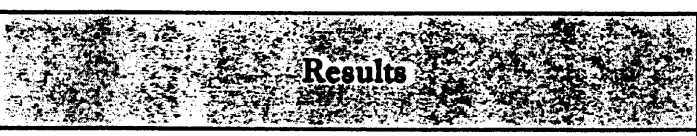 \\
\hline $\begin{array}{l}\text { Groundwater Flow } \\
\text { Characterization }\end{array}$ & $\begin{array}{l}\text { Trend-surface analysis of well } \\
\text { water-level data }\end{array}$ & $\begin{array}{l}\text { Quantitative determination of groundwater flow } \\
\text { direction and hydraulic gradient }\end{array}$ \\
\hline $\begin{array}{c}\text { Barometric Response } \\
\text { Evaluation }\end{array}$ & $\begin{array}{l}\text { Well water-level response } \\
\text { characteristics to barometric } \\
\text { changes }\end{array}$ & $\begin{array}{l}\text { Aquifer/well model identification, vadose zone } \\
\text { property characterization, correction of hydrologic } \\
\text { test responses for barometric pressure fluctuations }\end{array}$ \\
\hline Slug Testing & $\begin{array}{l}\text { Multi-stress level tests } \\
\text { conducted at each well site }\end{array}$ & Local $K_{h}, T$ of aquifer surrounding well site. \\
\hline $\begin{array}{l}\text { Tracer-Dilution } \\
\text { Testing }\end{array}$ & $\begin{array}{l}\text { Monitoring dilution of } \\
\text { administered tracer at } \\
\text { injection well site }\end{array}$ & $\begin{array}{l}\text { Vertical distribution of } K_{h} \text {, groundwater flow } \\
\text { velocity at injection well location }\end{array}$ \\
\hline $\begin{array}{c}\text { In-Well Vertical Tracer } \\
\text { Test }\end{array}$ & $\begin{array}{l}\text { Monitoring the vertical } \\
\text { movement of tracer within } \\
\text { the well screen }\end{array}$ & $\begin{array}{l}\text { Determination of vertical flow within the } \\
\text { monitoring well screen section }\end{array}$ \\
\hline Tracer Pumpback & $\begin{array}{l}\text { Pumping/monitoring of } \\
\text { recovered tracer and } \\
\text { associated pressure response } \\
\text { in monitoring wells }\end{array}$ & $\begin{array}{l}\text { Large-scale, interwell } n_{e}, K_{h}, K_{v} / K_{h}, K_{h x} / K_{h y}, T, S \text {, } \\
S_{y}\end{array}$ \\
\hline $\begin{array}{l}\text { Step-Drawdown } \\
\text { Test }\end{array}$ & $\begin{array}{l}\text { Determine well water-level } \\
\text { response to selected pumping } \\
\text { rates }\end{array}$ & Well loss characteristics \\
\hline
\end{tabular}

Hydrologic parameters:

$\begin{array}{rll}\mathrm{K}_{\mathrm{h}} & = & \text { horizontal hydraulic conductivity; }(\mathrm{L} / \mathrm{T}) \\ \mathrm{K}_{\mathrm{v}} / \mathrm{K}_{\mathrm{h}} & = & \text { vertical anisotropy; (dimensionless) } \\ \mathrm{K}_{\mathrm{hx}} / \mathrm{K}_{\mathrm{hy}} & = & \text { horizontal anisotropy; (dimensionless) } \\ \mathrm{T} & = & \text { transmissivity; }\left(\mathrm{L}^{2} / \mathrm{T}\right) \\ \mathrm{S} & = & \text { storativity; (dimensionless) } \\ \mathfrak{n}_{\mathrm{e}} & = & \text { effective porosity; (dimensionless) }\end{array}$


V.G. Johnson

September 26, 2000

Pg. 9

Table 2. FY-99 and FY-00 Hydraulic Property Test Analysis Summary for WMA TX-TY, T, and S-SX

\begin{tabular}{|c|c|c|c|c|}
\hline 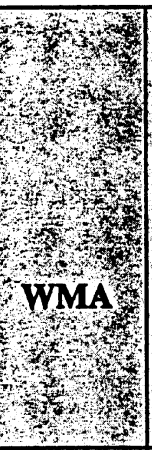 & 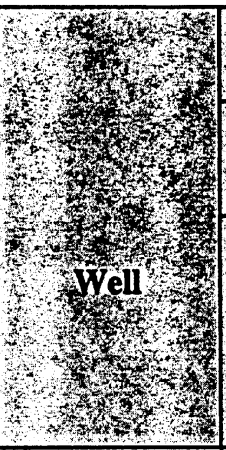 & 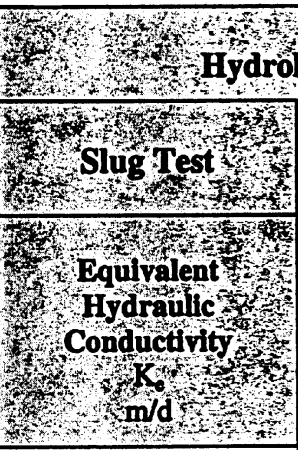 & 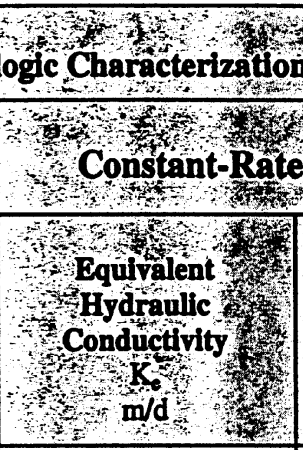 & 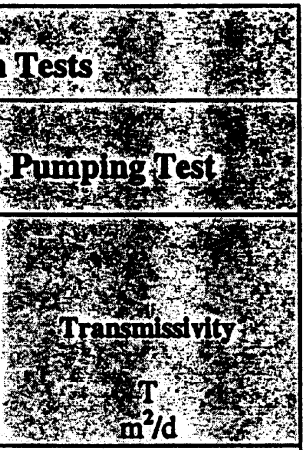 \\
\hline \multirow{5}{*}{ TX-TY } & 299-W10-26 & $1.40-1.95$ & 1.5 & 82 \\
\hline & 299-W14-13 & $1.66-2.43$ & 2.4 & 135 \\
\hline & 299-W14-14 & $2.44-2.87$ & -- & -- \\
\hline & $299-W 15-40$ & $0.88-1.22$ & -- & -- \\
\hline & $299-W 15-41$ & $15.1-19.5^{*}$ & $19.6^{* *}$ & $1130 * *$ \\
\hline \multirow{2}{*}{$\mathbf{T}$} & 299-W10-23 & $1.65-2.35$ & -- & -- \\
\hline & 299-W10-24 & $1.04-1.68$ & 1.2 & 66 \\
\hline \multirow{3}{*}{ S-SX } & $2-W 22-48$ & $1.55-1.98^{*}$ & $1.81^{* *}$ & $127^{* *}$ \\
\hline & 2-W22-49 & $6.92-8.20^{*}$ & $7.17^{* *}$ & $520^{* *}$ \\
\hline & 2-W22-50 & $5.18-5.46^{*}$ & $5.24^{* *}$ & $385^{* *}$ \\
\hline
\end{tabular}

Note: unless otherwise indicated, slug test analysis range represents the average analysis value for the Bouwer and Rice and type-curve methods

* $\quad$ slug test results do not include analysis results for Bouwer and Rice method; listed range will be updated when analysis results are complete in FY-01

** preliminary pumping test analysis values, subject to revision; to be documented in FY-01

Ke assumes aquifer with uniform hydraulic conductivity value

-- $\quad$ constant-rate pumping test not conducted at the well site 
V.G. Johnson

September 26, 2000

Pg. 10

Table 3. FY-99 and FY-00 Tracer-Dilution Test Analysis Summary for WMA TX-TY, T, and S-SX

\begin{tabular}{|c|c|c|c|c|c|c|c|c|}
\hline \multirow{2}{*}{ 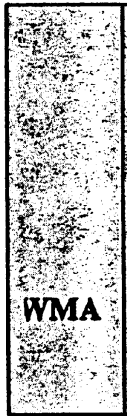 } & \multirow{2}{*}{ 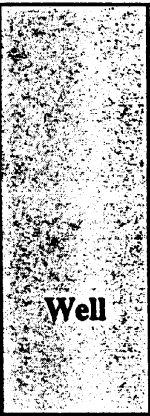 } & \multirow{2}{*}{ 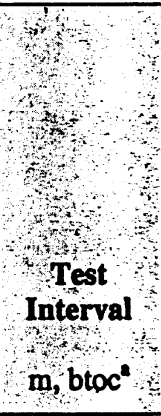 } & \multicolumn{6}{|c|}{ 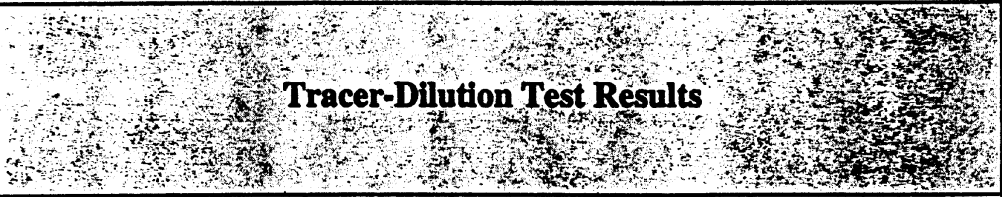 } \\
\hline & & & 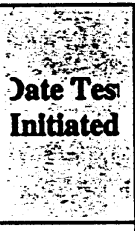 & $\begin{array}{l}\text { Total } \\
\text { Dilution } \\
\text { Time } \\
\text { st } \\
\text { min }\end{array}$ & $\begin{array}{l}\text { Average } \\
\text { Initial } \\
\text { Tracer } \\
\text { Concent. } \\
\text { c. } \\
\text { mgll }\end{array}$ & $\begin{array}{l}\text { Average } \\
\text { Final } \\
\text { Tracer } \\
\text { Concent. } \\
\mathrm{CC}_{\mathrm{mg} / \mathrm{L}}\end{array}$ & $\begin{array}{l}\text { W } \\
\text { A verage } \\
\text { Nell Flor } \\
\text { Yelocity } \\
\text { v }_{\mathbf{v}} \\
\text { m/d }\end{array}$ & 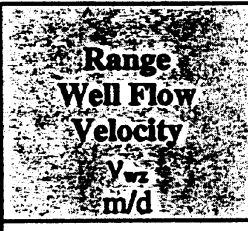 \\
\hline \multirow{3}{*}{ TX-TY } & $2-W 10-26$ & $67.4-77.8$ & 4/23/99 & 7,259 & 219 & $<1.0$ & $\begin{array}{c}\text { vf } \\
(0.086) \\
\end{array}$ & $\begin{array}{c}\text { vf } \\
\text { (downward) } \\
\end{array}$ \\
\hline & 2-W14-13 & $67.1-77.9$ & $3 / 26 / 99$ & 8,575 & VF & VF & VF & $\begin{array}{c}\text { VF } \\
\text { (downward) }\end{array}$ \\
\hline & $2-W 15-41$ & $66.3-71.1$ & $5 / 8 / 00$ & 2,714 & 152 & $<1.5$ & 0.311 & $0.232-0.401^{*}$ \\
\hline $\mathbf{T}$ & $2-W 10-24$ & $72.4-82.6$ & 4/9/99 & 17,455 & 148 & 26 & 0.012 & $0.009-0.017^{*}$ \\
\hline \multirow{4}{*}{ S-SX } & 2-W22-48 & $70.5-74.3$ & $5 / 11 / 00$ & 15,730 & 141 & 39 & 0.007 & $0.002-0.023^{* *}$ \\
\hline & 2-W22-49 & $67.3-71.9$ & $4 / 17 / 00$ & 4,175 & 145 & 4.0 & $\begin{array}{c}\text { vf } \\
(0.086) \\
\end{array}$ & $\begin{array}{c}\mathbf{v f} \\
\text { (upward) }\end{array}$ \\
\hline & \multirow[b]{2}{*}{ 2-W22-50 } & \multirow[b]{2}{*}{$67.5-71.9$} & $\begin{array}{c}5 / 1 / 00 \\
\text { (Test \#1) }\end{array}$ & 5,765 & 190 & 5.2 & 0.066 & relatively uniform \\
\hline & & & $\begin{array}{c}5 / 26 / 00 \\
\text { (Test \#2) }\end{array}$ & 7,240 & 148 & 6.5 & 0.046 & relatively uniform \\
\hline
\end{tabular}

* permeability profile indicates highest permeability (highest flow velocity) near the middle of well screen; lowest permeability near top

** permeability profile indicates highest permeability (flow velocity) near top of well screen, becoming progressively lower with depth within well screen

Co estimated initial tracer concentration based linear back-projection of average well screen conditions

$C_{t} \quad$ average observed well-screen tracer concentration at termination of test

$v_{w} \quad$ average groundwater flow velocity within well

$v_{w z} \quad$ groundwater flow velocity range within well determined from individual probe/depth-settings

vf slight vertical flow conditions detected adversely affect tracer test results; vertical flow direction indicated in parentheses

VF significant vertical flow conditions in well invalidating tracer-dilution test; vertical flow direction indicated in parentheses 
V.G. Johnson

September 26, 2000

Pg. 11

Table 4. FY-99 and FY-00 Tracer-Pumpback Test Analysis Summary for WMA TX-TY, T, and S-SX

\begin{tabular}{|c|c|c|c|c|c|c|c|c|c|}
\hline 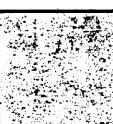 & $\begin{array}{r}x^{2} \\
-1 \\
\end{array}$ & $\begin{array}{l}x+1, \\
4\end{array}$ & $\begin{array}{r}4 \\
4 \\
4 \\
4\end{array}$ & 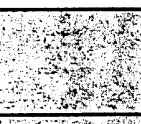 & Hydrolo & fic Charact & rization Te & sts & (6) \\
\hline 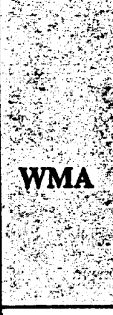 & 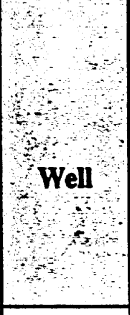 & 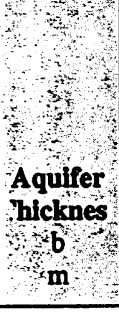 & 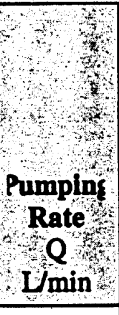 & 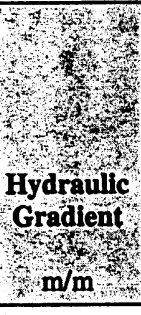 & 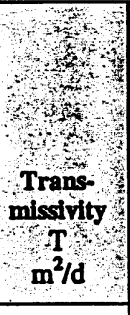 & 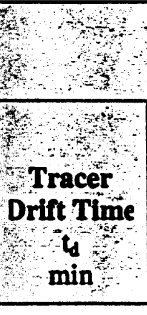 & $\begin{array}{c}\text { Tracer P } \\
\text { Trat } \\
\text { Tracer } \\
\text { Recovery } \\
\text { Time } \\
\text { to } \\
\text { min }\end{array}$ & 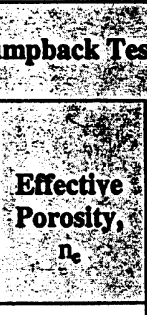 & 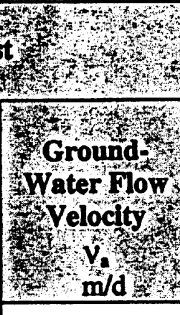 \\
\hline \multirow{3}{*}{ TX-TY } & $2-W 10-26$ & 55.0 & 39.5 & 0.00073 & 82 & 7,259 & 16.0 & $\begin{array}{c}\text { vf } \\
(0.010)\end{array}$ & $\begin{array}{c}\text { vf } \\
(0.124)\end{array}$ \\
\hline & 2-W14-13 & 55.0 & 48.9 & 0.00073 & 135 & 8,575 & 43.3 & $\begin{array}{c}\text { VF } \\
(0.009)\end{array}$ & $\begin{array}{c}\text { VF } \\
(0.191)\end{array}$ \\
\hline & 2-W15-41 & 57.6 & 60.4 & 0.00129 & $1130^{*}$ & 2,714 & 109.0 & $0.068^{*}$ & $0.374^{*}$ \\
\hline $\mathrm{T}$ & 2-W10-24 & 54.0 & 41.2 & 0.00172 & 66 & 17,455 & 37.1 & 0.072 & 0.029 \\
\hline \multirow{4}{*}{ S-SX } & 2-W22-48 & 70.1 & 7.0 & 0.00180 & $127^{*}$ & 15,730 & 159.1 & $0.257^{*}$ & $0.013^{*}$ \\
\hline & 2-W22-49 & 72.5 & 42.2 & 0.00206 & $520^{*}$ & 4,175 & 14.9 & $\begin{array}{c}\text { VF } \\
\left(0.671^{*}\right)\end{array}$ & $\begin{array}{c}\text { VF } \\
\left(0.022^{*}\right)\end{array}$ \\
\hline & \multirow[b]{2}{*}{ 2-W22-50 } & \multirow[b]{2}{*}{73.5} & $\begin{array}{c}28.5 \\
\text { (Test \#1) } \\
\end{array}$ & 0.00206 & $385^{*}$ & 5,765 & 43.4 & $0.354^{*}$ & $0.030^{*}$ \\
\hline & & & $\begin{array}{c}29.2 \\
\text { (Test \#2) }\end{array}$ & 0.00206 & $385^{*}$ & 7,240 & 108.8 & $0.221^{*}$ & $0.049^{*}$ \\
\hline
\end{tabular}

* preliminary hydraulic property estimate values (T): tracer pumpback results subject to revision

to time tracer allowed to drift from well into surrounding aquifer prior to pumpback

$t_{p}$ time required to recover $50 \%$ of the tracer mass during the pumpback

$v$ groundwater flow velocity within aquifer

(vf) slight vertical flow conditions in well detected; tracer test estimates for $n_{e}$ and $v_{a}$ are questionable

VF significant vertical flow conditions in well detected; tracer test estimates for $\mathrm{n}_{\varepsilon}$ and $\mathrm{v}_{\mathbf{a}}$ are highly questionable 
V.G. Johnson

September 26, 2000

Pg. 12

Table 5. FY-99 and FY-00 Groundwater Flow Characterization Results Based on TrendSurface Analysis for WMA TX-TY, T, and S-SX

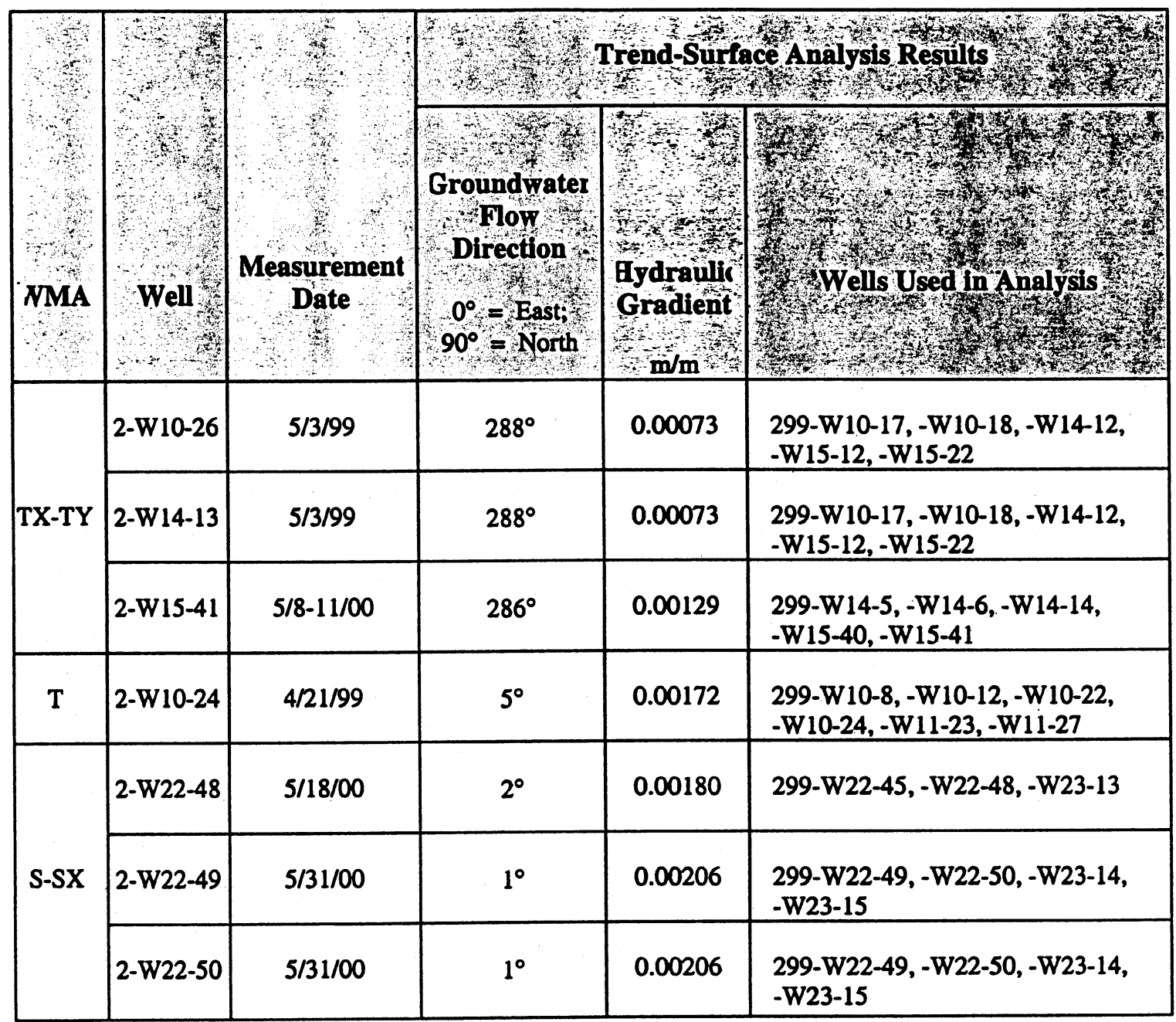




\section{Distribution}

No. of

\section{Copies}

OFFSITE

C. Abraham

U.S. General Accounting Office

825 Jadwin Ave., MSIN \#A1-80

Richland, WA 99352

2 Confederated Tribes and Bands of the

Yakama Indian Nation

Environmental Restoration Waste

Management Program

P.O. Box 151

Toppenish, WA 98948

ATTN: W. Riggsbee

R. Jim

2 Confederated Tribes of the Umatilla Indian

Reservation

P.O. Box 638

Pendleton, OR 97801

ATTN: B. Burke

T. Gilmore

T. French

Savannah River Site

Aiken, SC 29802

2 Nez Perce Tribe

Nez Perce Tribal Department of

Environmental Restoration and Waste

Management

P.O. Box 365

Lapwai, ID 83540

ATTN: D. Powaukee

S. Sobczyk
No. of

Copies

R. Patt

Oregon Water Resources

Water Resources Department

555 13th Street Northeast

Salem, OR 97301

G. Pollet

Heart of America Northwest

Heart of American Northwest, Suite 208

Seattle, WA 98101

P. Rogers

Jacobs Engineering Group, Inc.

3250 W. Clearwater Ave.

Kennewick, WA 99336

S. Van Verst

Washington State Department of Health

Airdustrial Park, Bldg. 5

Olympia, Washington 98504

\section{ONSITE}

17 DOE Richland Operations Office

C. E. Clark

A5-15

M. J. Furman (7)

$\mathrm{H} 0-12$

J. B. Hall

A5-15

R. D. Hildebrand

$\mathrm{H} 0-12$

R. A. Holten

$\mathrm{H} 0-12$

E. M. Mattlin

A5-15

J. K. McClusky

S7 -54

E. J. Rasmussen

A5-58

K. M. Thompson

H0-12

R. M. Yasek

H6-60

Public Reading Room

Distr.1 
No. of

Copies

3 Bechtel Hanford, Inc.

J. F. Armatrout

$\mathrm{H} 4-02$

K. R. Fecht

$\mathrm{H} 0-02$

B. H. Ford

$\mathrm{H} 0-02$

2 Fluor Daniel Hanford, Inc.

E. A. Fredenburg

H6-12

F. A. Ruck

H6-23

Fluor Daniel Northwest, Inc.

F. M. Mann

B4-43

7 CH2M HILL Hanford Group

R. J. Brown

T4-08

C. B. Bryan

T4-07

B. G. Erlandson

R1-51

T. E. Jones

$\mathrm{H} 0-22$

A. J. Knepp

$\mathrm{H} 0-22$

D. A. Myers

G3-21

R. D. Wojtasek

G3-21

2 MACTEC-ERS

J. F. Bertsch

B1-42

R. G. McCain

B1-42

\section{U.S. Environmental Protection Agency}

D. R. Sherwood

B5-01

6 Washington State Department of Ecology

M. J. Brown

S. L. Dahl

B5-18

D. N. Goswami

B5-18

B5-18

J. A. Hedges

A. D. Huckaby

B5-18

B5-18

S. McKinney (Olympia)
No. of

Copies

2 Waste Management Federal Services, Inc.

J. C. Sonnichsen

H6-26

M. I. Wood

H6-06

\section{Waste Management Northwest}

M. G. Gardner

H1-11

59 Pacific Northwest National Laboratory

K. J. Cantrell K6-81

J. Bush K6-96

C. J. Chou (5) K6-81

P. E. Dresel K6-96

G. W. Gee K9-33

M. J. Hartman K6-96

F. N. Hodges (20) K6-81

G. R. Holdren K6-81

D. G. Horton K6-81

V. G. Johnson K6-96

S. P. Luttrell (5) K6-96

S. V. Mattigod K6-81

W. J. Martin K6-81

R. B. Mercer K6-96

L. F. Morasch K6-86

S. M. Narbutovskih $\quad$ K6-81

T. L. Page K9-18

S. P. Reidel K6-81

R. Schalla K6-96

R. J. Serne K6-81

R. M. Smith K6-96

F. A. Spane K6-96

P. D. Thorne K9-33

D. Vela K6-96

B. A. Williams K6-81

Information Release Office (7) K1-06 